\title{
Entre alimentos y tradiciones EN LA CIUDAD DE LOS DIOSES
}

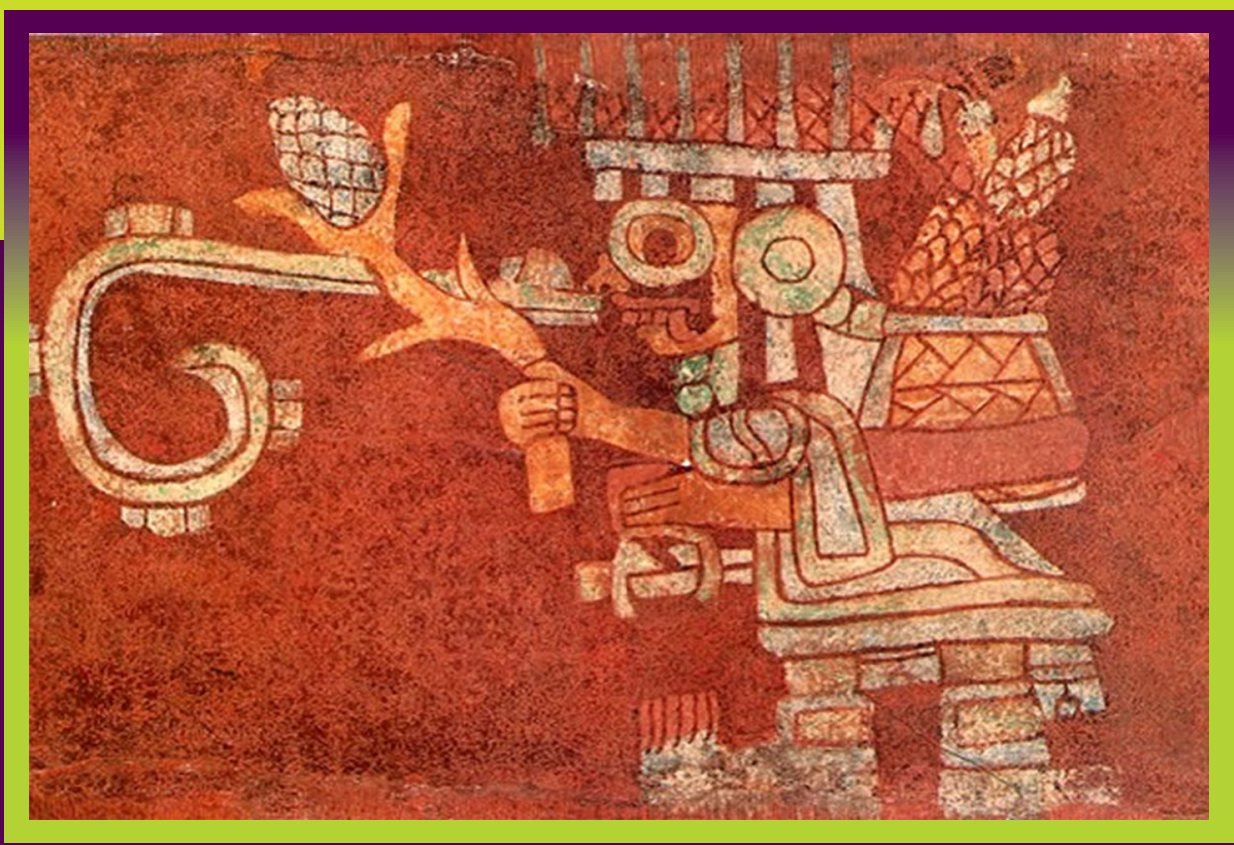

Raúl Valadez Azúa | Editor

Red de Ciencias Aplicadas a la Investigación y Conservación del Patrimonio Cultural

Universidad Nacional Autónoma de México Instituto de Investigaciones Antropológicas 


\section{Entre alimentos y tradiciones EN LA CIUDAD DE LOS DIOSES}





\title{
Entre alimentos y tradiciones EN LA CIUDAD DE LOS DIOSES
}

\author{
Raúl Valadez Azúa | Editor
}

Red de Ciencias Aplicadas a la Investigación y Conservación del Patrimonio Cultural

Universidad Nacional Autónoma de México Instituto de Investigaciones Antropológicas

México, 2017 
EDITOR:
Raúl Valade

ELABORACIÓN DE TEXTOS:

Cristina Adriano

Ana Aguirre

Luis Barba

Laura Beramendi Jorge Blancas

Blanca Zoila González

Galia González

Emilio Ibarra

Diana Martínez

Emily McClung

Agustín Ortiz

Bernardo Rodríguez

Raúl Valadez

Judith Zurita

ADECUACIÓN DE TEXTOS: María del Rocío Téllez Estrada

RESPONSABLE DE LA RED CAICPC Luis Alberto Barba Pingarrón
JEFE DEL DEPTO. DE PUBLICACIONES DEL IIA: Rafael Antonio Pérez-Taylor y Aldrete

CORRECCIÓN DE ESTILO: Jaquelina Ibarra

CUIDADO EDITORIAL:

Raúl Valadez

DISEÑO EDITORIAL: Jonathan R. Valadez

IMAGEN DE PORTADA:

Zacuala, Portico 3, Mural 3 Tláloc como dios del maiz (según sejourne) (pueblos originarios.com/meso/ valle/teotihuacan/murales.swf) Imagen de cuarta de forros: Tetitla, Portico 3, Puma (https://www.flickr. com/photos/63296840@N06/5837580591/lightbox/

REALIZACIÓN DE PORTADA:

Jonathan R. Valadez

GESTION ADMINISTRATIVA:

Diana Franco

\section{OCTUBRE DE 2017}

Esta obra fue financiada a través de la Red de Ciencias Aplicadas a la Investigación y Conservación del Patrimonio Cultural del Consejo Nacional de Ciencia y Tecnología.

Primera edición: 2017

Término de la edición: 6 de octubre de 2017

D.R. 2017 @

RED DE CIENCIAS APLICADAS A LA INVESTIGACIÓN Y CONSERVACIÓN DEL PATRIMONIO CULTURAL DEL CONSEJO NACIONAL DE CIENCIA Y TECNOLOGÍA

D.F. 2017 ๔

UNIVERSIDAD NACIONAL AUTÓNOMA DE MÉXICO

Ciudad Universitaria, C.P. 04510, Coyoacán,

México, Ciudad de México

INSTITUTO DE INVESTIGACIONES ANTROPOLÓGICAS

www.iia.unam.mx

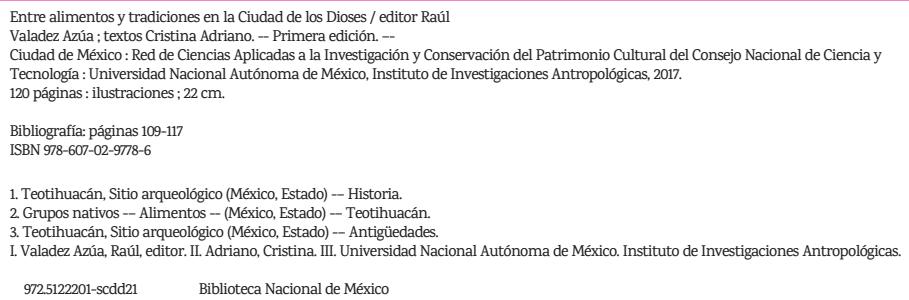

ISBN: 978-607-02-9778-6

Esta edición y sus caracteristicas son propiedad de la Universidad Nacional Autónoma de México

Prohibida la reproducción total o parcial por cualquier medio sin la autorización escrita del titular de los derechos patrimoniales.

D.R. Derechos reservados conforme a la ley.

Impreso y hecho en México

Printed in Mexico 


\section{ÍNTDICE}

Prólogo

Comer y ofrendar: dos actividades que nos

ilustran sobre la vida del teotínuacano.

7. Antecedentes de la gran ciudad

Teotihuacan, la gran ciudad del continente americano

El mundo Mesoamericano

Breve historia de Teotihuacan

La vida del teotihuacano y su alimentación

La ciencia acepta el reto

Si regresáramos al pasado, ¿qué querríamos conocer de

la alimentación de los teotihuacanos?

11. Cómo se estudía lo antíguo

La interdisciplina: una ventana para ver el pasado

Laboratorios de ciencias aplicadas

Un interesante campo de estudio: la osteología humana

y las enfermedades causadas por desnutrición

Otros campos de investigación de relevancia para la

alimentación en tiempos antiguos: isótopos y elementos traza.

Preguntas generadoras de investigación y formas de responderlas

112. Conociendo la alímentación teotíhuacana

Explorando una casa teotihuacana a la hora de la comida

Mirando la despensa teotihuacana

La comida en las horas de trabajo

Comidas y ofrendas

¿Cómo llegaba la comida a las casas?

¿De dónde venía el alimento que se comía?

¿Todos en Teotihuacan comían igual?

El final de la buena alimentación

1V. Aprendiendo de la experiencia teotínuacana

El legado teotihuacano en la actualidad

Reflexiones finales

V. Bibliografía 
Con nuestro sincero agradecimiento a todos los arqueólogos e investígadores de diversas áreas que a lo largo de un siglo dedicaron su mejor esfuerzo al estudio de la antígua ciudad de Teotihuacan. 


\section{Prólogo}

Todos los mexicanos vivimos profundamente lo relacionado 1 con las culturas que habitaron este territorio antes del siglo XVI. Aprendemos desde niños que parte de nuestro esquema de vida tiene su origen en esa época y al menos en lo que se refiere a la alimentación no es exageración, pues disponemos de un acervo de tradiciones que son completamente diferentes de lo español y además nos distinguen plenamente de cualquier otra sociedad del mundo. El enorme conjunto de alimentos elaborados con el maíz, el uso del nopal como alimento tradicional, la manera como disfrutamos comer una tuna, la importancia de los guajolotes en las fiestas, la delicia de una quesadilla de cuitlacoche, el gusto por un taco de chapulines con guacamole. Todos estos son alimentos que conocemos, consumimos y forman parte de nuestra cotidianeidad, sin embargo más allá de las fronteras culturales mexicanas constituyen algo desconocido, casi increíble, pues al maíz se le come bajo la forma de mazorca cocida, desconocen que el nopal y la tuna son comestibles, piensan que el guajolote sólo se consume en Navidad o en el Día de Acción de Gracias en los Estados Unidos, y jamás imaginan que el hongo de una espiga de maíz o un grillo pueden comerse sin riesgo.

La gran mayoría de los mexicanos está orgullosa de nuestra riqueza culinaria, pero ¿qué tan remota es? ¿Sabemos si en tiempos antiguos ya se disponía de alimentos como los que actualmente forman parte de nuestra tradición alimentaria? Esto es importante conocerlo, pues ante la avalancha actual de publicidad de alimentos chatarra, comida industrializada, sintética y carente de calidad nutricional, nada mejor que voltear hacia nuestro universo de platillos y tradicionales guisos para seguir aprovechándolos y deleitándonos con ellos. 
Este libro busca ilustrar al lector acerca de las preguntas formuladas, partiendo de la experiencia y el conocimiento que de la alimentación se tienen de una cultura en especial: la teotihuacana. Es relativamente fácil encontrar información sobre lo que se comía en tiempos prehispánicos, sobre todo en obras coloniales, pero la base de la presente obra es el estudio científico que se ha realizado en los últimos cuarenta años desde diversas disciplinas las cuales forman parte del quehacer académico de los autores, todo ello volcado hacia esta cultura, la cual constituye uno de los íconos distintivos de lo mesoamericano.

Entre alimentos y tradíciones en la Ciudad de los Dioses es producto de dos fuentes de información y conocimiento arqueológico. Por un lado tenemos estudios diversos, algunos generados desde hace varias décadas, que involucran la historia de Teotihuacan, su organización y numerosos datos respecto de sitios arqueológicos y hallazgos relacionados. Por otro lado tenemos el trabajo de los catorce autores, integrantes del Seminario Permanente de Antropología y Ciencias Aplicadas del Instituto de Investigaciones Antropológicas de la Universidad Nacional Autónoma de México, quienes hemos estudiado los materiales y sitios teotihuacanos de muy diversas formas y, en algunos casos, desde hace muchos años. La experiencia y el conocimiento científico acumulado por este grupo de académicos abarca más de 250 años, lo bastante grande para elaborar una obra como la presente, donde muy diversas disciplinas integran sus conocimientos para ofrecer al lector una imagen del tema de la alimentación dentro de esa gran cultura.

Esta obra es producto de la investigación científica de México involucrada con la arqueología. La información aquí plasmada ha sido presentada en numerosos eventos y obras de carácter científico, por lo que es el momento de llevarla al pleno de la sociedad mexicana, transformada en un producto integrado, 
ameno, interesante, apto para el apoyo escolar, para quien se interesa por la historia de México de forma personal o también para un académico que puede ver en la obra una síntesis que apoye su labor.

Para cubrir sus objetivos, este libro fue construido en un formato de divulgación, con asesoría de personas con experiencia en el área y en la docencia. Es importante insistir que es producto de nuestras investigaciones científicas adaptadas a un formato de divulgación para hacerlo accesible a un universo amplio de lectores.

Entre alimentos y tradíciones en la Ciudad de los Dioses está dividido en cinco partes. Cada una posee un cuerpo de información con imágenes de apoyo y al final una lista de números que corresponden a las referencias bibliográficas empleadas, mismas que se encuentran al final de la obra. Esto se ha hecho con el propósito de ofrecer una lectura fluida, pero dado que la mayor parte de los capítulos tuvieron una bibliografía básica, a veces extensa, es que al final se incluye la lista de obras empleadas pero indicándola sólo a través del número correspondiente.

La primera parte es una introducción sobre lo que ha sido el estudio de Teotihuacan a lo largo de un siglo y cómo es que el tema de la alimentación ha sido abordado desde diferentes perspectivas. La segunda parte involucra la presentación breve, pero indispensable acerca de la forma como se realizan en la actualidad las investigaciones de corte interdisciplinario y métodos de estudio, tomando como apoyo la información contenida en el libro publicado en 2016 por nuestro grupo: Viaje al inframundo. Las ciencias y la muerte.

La tercera parte, "Conociendo la alimentación teotihuacana”, es la presentación de la información disponible hasta este momento pero organizada tal y como la podríamos ir 
conociendo si pudiéramos remontarnos al pasado. La cuarta es una invitación a la reflexión acerca de cuánto de ese marco presentado sobre la alimentación en Teotihuacan podemos observarlo actualmente y de su importancia como parte de nuestro legado cultural, el cual vale la pena proteger tanto por ser parte de nuestra tradición como por razones de salud.

Por último se ofrece la bibliografía que se empleó en la obra, numerada y organizada en orden alfabético. Las obras presentadas no son, ni con mucho, todo lo que se ha publicado del tema, pero sí constituyen un conjunto de obras que representan un buen punto de partida para todo aquel que desee seguir conociendo sobre este interesante tema.

Raúl Valadez Azúa

Agosto de 2017 


\section{COMER Y OFRENDAR:}

dos actividades que nos ilustran sobre la vida del teotihuacano 
entro de todo el universo de actividades científicas que involucran el estudio de la vida del ser humano de tiempos pasados, sin duda lo referente a su alimentación es de lo más relevante, pues implica un conjunto de interacciones entre los individuos, con su ambiente, entre comunidades, entre culturas, incluso entre naciones.

Debido a esto no es de extrañar que el tema de la alimentación y la cultura teotihuacana haya sido abordado en numerosas ocasiones, pues su condición de gran ciudad siempre llevó a la interrogante de cuál habría sido el esquema de organización que permitió dar de comer a una población que, hace 30 años, se llegó a calcular en 250,000 habitantes.

Desafortunadamente durante las primeras décadas del siglo XX, los esfuerzos se dieron de manera puntual, aislados, frecuentemente superados por los prejuicios que conducían a una imagen controvertida, pues frente a la magnificencia arquitectónica se daba por hecho que la población en general vivía en una hambruna constante. Para los investigadores de esa época no era tan relevante la organización manifiesta en las evidencias arqueológicas ni el esplendor que claramente dejaban ver sus grandes construcciones si no se ajustaba al modelo europeo de una ciudad, aunque fuera de la Edad Media. Un punto clave fue saber si sus esquemas de producción y abasto de alimentos eran semejantes a los de ciudades antiguas de Europa o Medio Oriente, si los resultados eran negativos, la conclusión era que los habitantes de la ciudad habían vivido una larga historia de limitaciones y penurias en lo que a su comida se refería.

Debido a esto se creó la imagen de una ciudad cuyo abasto dependía casi exclusivamente del esfuerzo individual, como una gigantesca conglomeración de gente donde cada quien debía buscar cómo sobrevivir con sus propios medios y aunque las evidencias botánicas apoyaban la idea del desarrollo agrícola, la ausencia de ganado doméstico como el europeo necesariamente llevaban a la conclusión de que los recursos cárnicos eran prácticamente inexistentes, es decir, nula organización y limitadas fuentes de alimento. Bajo este 
pensamiento no es de extrañar que el hallazgo de restos humanos con claras evidencias de haber sido destazados y cocidos se convirtiera en la mejor prueba de que era tal la limitación de alimentos que la respuesta obligada había sido la antropofagia.

Estos esquemas parciales y tendenciosos perduraron mientras las investigaciones involucraban una sola disciplina, una sola mente. En los últimos cuarenta años la tendencia ha ido girando en sentido contrario, cambiando el esfuerzo individual por el trabajo en equipo y la visión personal por la integración de datos que finalmente permiten alcanzar resultados con firme base científica.

Durante los años cincuenta del siglo pasado, la evidencia arqueológica para la alimentación en Teotihuacan se limitaba esencialmente a indicadores paleopatológicos en los restos osteológicos humanos, como lesiones asociadas con la calidad relativa de la dieta. Hace cuarenta y cinco años, en la 37a reunión anual de la Sociedad para la Arqueología Americana, se presentaron los resultados del primer estudio de restos macrobotánicos recuperados de excavaciones estratigráficas (pozos de prueba) llevadas a cabo en Teotihuacan por colegas del Proyecto de Mapeo de Teotihuacán, dirigido este por el investigador René Millon de la Universidad de Rochester. Se describieron numerosas plantas carbonizadas, asociadas con los posibles restos de fogones en depósitos debajo de pisos en la unidad habitacional llamada Tetitla. Desafortunadamente no fue posible obtener fechas por radiocarbono por los costos y cantidades de carbono que se requerían en ese momento.

En un principio, el estudio de macrorrestos botánicos fue la única técnica al alcance de los arqueólogos para conocer aspectos ligados a la alimentación. Respecto del estudio de restos animales, fue en 1975 que se publicó la primera investigación en la que se describía la fauna recuperada de 20 sectores de Teotihuacan y fue escrita por David Starbuck. Aunque muchas de sus interpretaciones han sido superadas tuvo la virtud de que con ello dejó ver la importancia 
de estudiar estos materiales para así conocer la relevancia de este recurso al interior de una ciudad prehispánica.

Más adelante, a partir de los años ochenta, se han incorporado a la investigación diversas aplicaciones provenientes de diferentes áreas científicas, que en su conjunto ofrecen amplias posibilidades de obtener evidencias y explorar hipótesis imposibles de abordar en el pasado; entre ellas, los avances en las técnicas de radiocarbono y la posibilidad de obtener dataciones de muestras muy pequeñas con el uso del espectrómetro de masas, así como la incorporación del estudio de microrrestos botánicos como el polen, fitolitos y gránulos de almidón, los estudios químicos de pisos y otros contextos además de los residuos orgánicos en artefactos como la cerámica y la lítica, los estudios isotópicos y de elementos de traza en restos óseos humanos, y la recuperación de ADN antiguo entre otras aplicaciones, han contribuido de manera significativa al estudio de la alimentación de la población prehispánica del antiguo centro urbano.

Uno de los aspectos más relevantes derivados de este esfuerzo colectivo es la forma como lo nutricional y lo religioso se unían al momento en que se realizaba el consumo de alimentos. En otros tiempos se partía de que ambas actividades eran independientes en los objetivos y acciones, de forma que incluso se concluía que el hallazgo de restos de un guajolote, dentro de un entierro había significado alimento perdido, así de simple. En la actualidad disponemos de datos arqueológicos, de iconografía, de restos animales y vegetales, osteológicos y de la química del hueso que manifiestan dos cosas, en primer lugar que el susodicho estado de hambruna permanente de la población teotihuacana no existió y que todo ser vivo estaba involucrado en un universo simbólico paralelo al alimentario, es decir, lo nutricional y lo religioso no se excluían, sino se complementaban.

Justamente a partir de esta nueva visión podemos asegurar en el presente que aunque sí existió el consumo de carne humana en Teotihuacan, esta práctica estaba íntimamente ligada a aspectos 
religiosos como parte de ritos específicos, sin que involucrara en lo absoluto necesidades nutricionales. La alimentación del teotihuacano, en particular lo referente a la obtención de proteínas, era posible a través de numerosas especies animales, vegetales y fúngicas, mismas que estaban inmersas en un interesante sistema de abasto.

En esta época nuestro conocimiento sobre la vida al interior de una gran urbe de tiempos antiguos, como es el caso de Teotihuacan, es mucho mayor a lo que cualquiera se hubiera imaginado hace medio siglo, pues el esfuerzo de múltiples disciplinas ha permitido disponer de una enorme base informativa de cualquier aspecto que involucre a dicha cultura. Es, sin embargo, indispensable reflexionar acerca de que el continuo esfuerzo científico conduce a una permanente aportación de nueva información y por tanto siempre es esperable nuevas ideas, nuevos resultados, nuevas interpretaciones, que hagan que lo que hoy se ve como algo insuperable, en 20 años sea más bien un antecedente de una visión nueva y sin duda mejorada.

\section{Lista de las obras empleadas en la elaboración del capitulo}

$2,13,14,22,25,26,36,43$. 
1

\section{ANTECEDENTES \\ de la gran ciudad}




\title{
Teotíhuacan, la gran ciudad del continente americano
}

\begin{abstract}
todos se nos enseña que el hombre llegó al continente americano A hace más de 10,000 años, durante la etapa final de la Edad del Hielo, y que poco a poco se fue dispersando. Muchos de los grupos que llegaron a lo que hoy conocemos como México se establecieron en la mitad sur, aprovechando su clima más benigno, de condición húmeda, y que fluctúa de templado, en las partes altas, a cálido, en las zonas bajas.
\end{abstract}

\section{$\mathcal{E}$ l mundo mesoamericano}

Los beneficios de este clima favorecieron que en este territorio se desarrollara la agricultura hace unos 6,000 años y eso llevó a sus habitantes a establecerse en asentamientos sedentarios. Al paso de los años estos pueblos desarrollaron también costumbres y formas de pensar similares, por ejemplo, templos en la parte alta de pirámides escalonadas, economía agrícola basada en el maíz, uso de la nixtamalización para el preparado del grano de esta planta, dioses en común y más aún. Todos los pueblos que compartían estas

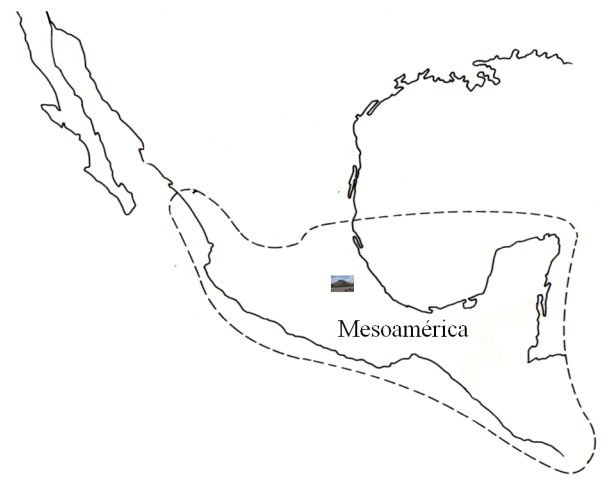

Figura 1. Mapa donde se observa la máxima extensión de Mesoamérica y la posición de Teotihuacan en ésta. (Elaboró Raúl Valadez). 
características se distribuyeron en el territorio que va de la parte media de México hasta Nicaragua, denominado "Mesoamérica" (Figura 1).

Desde el origen de la agricultura y el sedentarismo, las comunidades vivían primero en aldeas o pequeños poblados, con el paso del tiempo los asentamientos se fueron haciendo cada vez más grandes y complejos hasta hace unos dos mil años en que se funda Teotihuacan, la primera gran ciudad de América.

\section{El lugar donde se hacen los Dioses}

Teotihuacan existió un milenio antes de los mexicas, la cultura dominante en el centro de Mesoamérica al momento de la llegada de los españoles. Los mexicas, como casi todos los pueblos que llegaron y vieron las ruinas de la ciudad (Figura 2), se maravillaron de lo que tenían ante sus ojos y decidieron que las construcciones sin duda eran muy antiguas y que no habían sido hechas por humanos, sino por una especie diferente, gigantes, dicen algunos.

Esta idea fue empleada para elaborar una serie de mitos sobre dioses y eventos divinos ocurridos en la ciudad abandonada, siendo la más conocida la que refiere al origen del Sol y la Luna y que fue retomada en el siglo XVI por Fray Bernardino de Sahagún en su obra, Historia General de las Cosas de Nueva España (también conocida como Códíce F(orentíno). El encumbramiento de estas ruinas como antigua sede de los dioses llevaron, asimismo, a reconocerlas bajo el nombre de Teotihuacan, cuya traducción exacta es "El lugar donde se hacen los dioses", aunque en la concepción popular se le asocia más con "la ciudad de los dioses". 

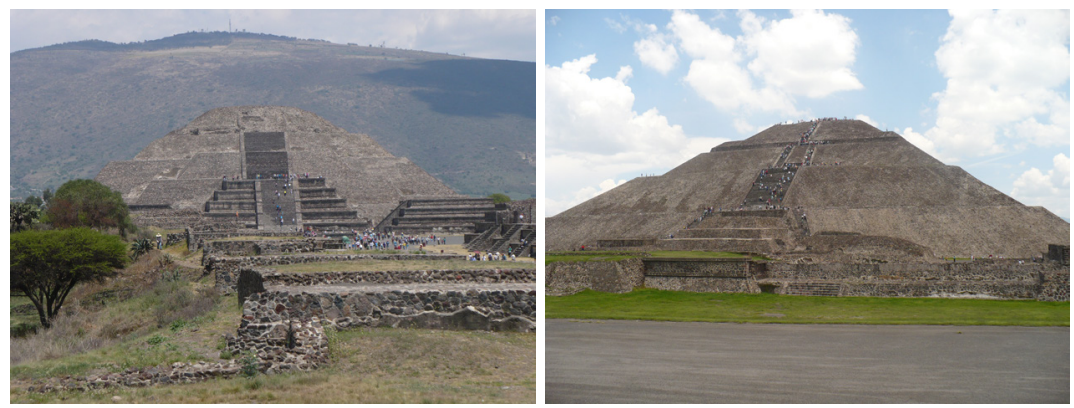

Figura 2. Vista de la Pirámide de la Luna con el llamado “Cerro Gordo” al fondo (izquierda) y Pirámide del Sol (derecha). (Fotografías de Raúl Valadez).

\section{Breve historia de Teotihuacan}

Esta ciudad se desarrolló en el valle que lleva su nombre y se encuentra a $50 \mathrm{Kms}$ de la Ciudad de México, a $62 \mathrm{Kms}$ de la ciudad de Pachuca, a $139 \mathrm{Kms}$ de la ciudad de Puebla y a $218 \mathrm{Kms}$ de la ciudad de Querétaro.

Su origen lo ubicamos en el siglo I antes de nuestra Era (Cuadro 1), asociado con el aprovechamiento del tezontle, roca porosa muy común en esta zona. Posteriormente controla la explotación de importantes minas de obsidiana ${ }^{1}$ presentes en la región. Otro paso fundamental de su desarrollo fue la construcción de grandes basamentos que serían los antecedentes de las que conocemos actualmente con el nombre de Pirámides de la Luna y del Sol, lo cual ocurrió desde el siglo I (años 0-100 de nuestra Era), en la llamada fase Tzacualli (Cuadro 1). La notoriedad y el interés que despertó todo esto, unido a la actividad volcánica que se estaba llevando a cabo en el sur de la Cuenca de México, en el Popocatepetl, el Xitle y otros, derivó en una migración masiva hacia esta ciudad. 


\begin{tabular}{|c|c|c|}
\hline $\begin{array}{c}\text { Temporalidad (años de } \\
\text { nuestra Era) }\end{array}$ & $\begin{array}{l}\text { Nombre de } \\
\text { la fase }\end{array}$ & Eventos principales \\
\hline $150-0$ (antes de nuestra Era) & Patlachique & $\begin{array}{l}\text { Origen de la ciudad. Economía basada en la } \\
\text { explotación de minas de obsidiana y del } \\
\text { tezontle }\end{array}$ \\
\hline $0-100$ & Tzacualli & $\begin{array}{l}\text { Incremento de la población, construcción de las } \\
\text { primeras etapas de las Pirámide del Sol y de la } \\
\text { Luna. }\end{array}$ \\
\hline $100-200$ & Miccaotli & $\begin{array}{l}\text { Construcción de la Calzada de los Muertos y de } \\
\text { la Ciudadela, nuevas fases constructivas de la } \\
\text { Pirámide de la Luna que "cubren" a las } \\
\text { anteriores. }\end{array}$ \\
\hline $200-350$ & Tlamimilolpa & $\begin{array}{l}\text { Diferencias entre los grupos de la élite. El } \\
\text { grupo asociado al Templo de Quetzalcoatl es } \\
\text { excluido y la pirámide es "clausurada" } \\
\text { colocando otra pirámide sobre ella. Gran } \\
\text { impulso político que le da a la ciudad una gran } \\
\text { importancia en Mesoamérica. Control de la ruta } \\
\text { de la obsidiana y la cal. Fuerte incremento de } \\
\text { población, del tamaño de la ciudad, } \\
\text { construcción de calles que corren paralelas y } \\
\text { perpendiculares, orientadas de acuerdo con la } \\
\text { Calzada de los Muertos. Construcción de la red } \\
\text { de drenaje subterráneo y de numerosas } \\
\text { unidades habitacionales, edificios ceremoniales } \\
\text { y administrativos. Las pirámides del Sol y de la } \\
\text { Luna adquieren sus dimensiones actuales. }\end{array}$ \\
\hline $350-550$ & Xolalpan & $\begin{array}{l}\text { Máximo desarrollo de la ciudad y máxima } \\
\text { influencia en Mesoamérica. Crisis al final del } \\
\text { periodo y conflictos sociales que derivaron en } \\
\text { violencia. }\end{array}$ \\
\hline $550-650$ & Metepec & $\begin{array}{l}\text { Decaimiento de la ciudad y extinción } \\
\text { progresiva. }\end{array}$ \\
\hline
\end{tabular}

Cuadro 1. Sinopsis de la historia teotihuacana.

En la llamada "Fase Miccaotli" (años 100-200 de nuestra Era) se realizan nuevas obras dentro de la zona ceremonial, como la gran calle que conocemos como "Calzada de los Muertos" a lo largo de la cual se construyeron numerosos edificios, por ejemplo las Pirámides del Sol y de la Luna en el extremo norte y la Ciudadela, con el Templo de Quetzalcoatl, más al sur (Figuras 2 y 3, Cuadro 1), concluyendo dos kilómetros adelante.

Datos de estudios diversos y comentarios de arqueólogos han impulsado la idea de que desde este periodo empezaron a surgir diferencias entre los diversos grupos de la élite teotihuacana respecto 
de la forma de conducir a la ciudad y a su economía. Se considera que en ese momento el grupo dirigente tenía a la Ciudadela como eje de sus actividades y a la serpiente como su símbolo distintivo, frente a otros, uno de los cuales estaba asociado al elemento felino y con las Pirámides del Sol y la Luna.

Se considera que estas diferencias llevaron a varios momentos críticos, incluso se llegó a proponer que algunos de los miembros
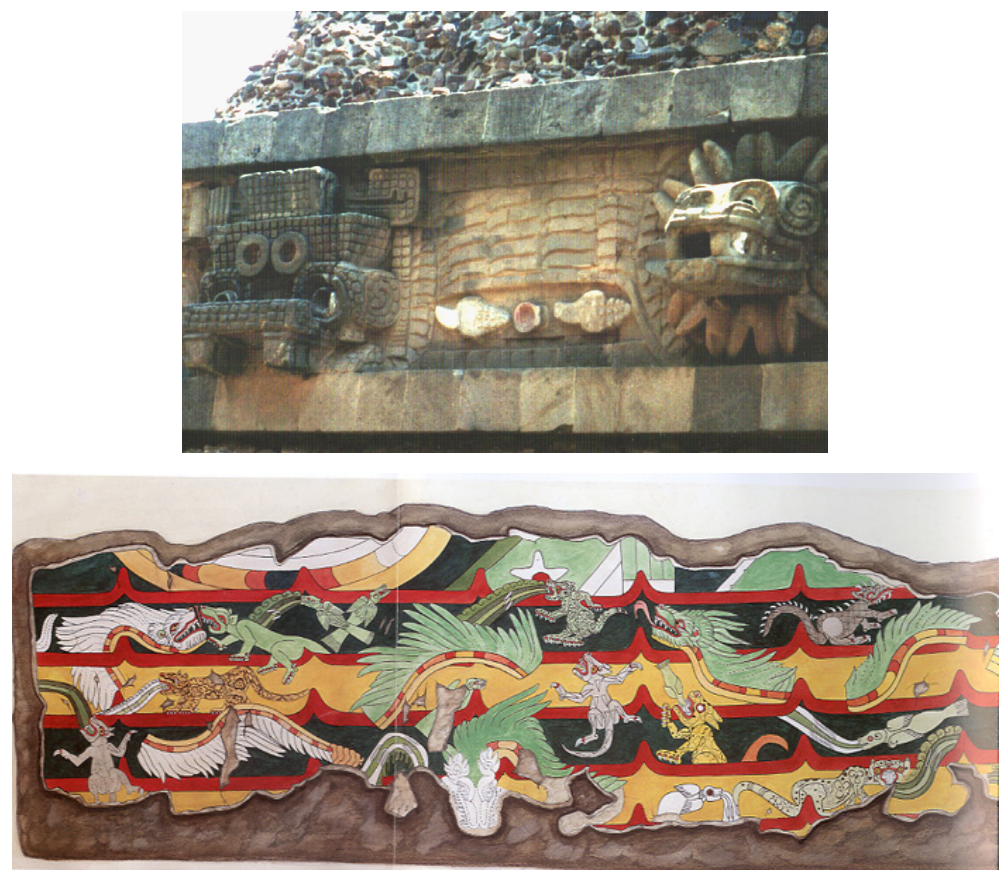

Figura 3. Arriba, sección de la cara oeste del Templo de Quetzalcoatl; el cual se considera que era la sede del poder al final de la fase Miccaotli e inicios de Tlamimilolpa. Posteriormente fue cubierta por la llamada "pirámide adosada", de la cual se conserva una parte. Abajo, reconstrucción del llamado "mural de los animales mitológicos", elaborado en la misma época, y donde se manifiesta un escenario de lucha entre grupos, tentativamente reflejo de los conflictos ocurridos.

(Fotografía de Raúl Valadez, imagen de mural tomada de https://quartodejade. wordpress.com/2010/02/06/nagual/) 
del grupo vinculado con la serpiente habrían sido sacrificados y enterrados dentro del Templo de Quetzalcoatl a inicios de la fase Tlamimilolpa. En todo caso se puede constatar que la figura de la serpiente, hasta entonces frecuente en esculturas y pinturas fue excluida, encumbrándose la del felino. Existe además un mural llamado "mural de los animales mitológicos" (Figura 3) donde este conflicto se manifiesta a través de un escenario que presenta el encuentro entre diversos animales, destacando las serpientes, los felinos y los peces. Más tarde, hacia el final de Tlamimilolpa (350 de nuestra Era), los miembros del grupo de la serpiente fueron expulsados de la ciudad y el propio templo fue cubierto por otra pirámide (a la cual se le denomina "pirámide adosada") con el objetivo de "sellar" permanentemente todo lo relacionado con esa parte de la historia de la ciudad.

Aparentemente los cambios que se dieron a nivel de la clase gobernante fueron benéficos para la Teotihuacan, pues a lo largo de la siguiente fase, llamada Tlamimilolpa, se realizan importantes acciones que derivan en su encumbramiento hasta convertirse en el lugar más importante de Mesoamérica.

Respecto de la ciudad, es el momento en que se dio un fuerte desarrollo urbano, convirtiéndola en un lugar con calles trazadas y un sistema de drenaje que desalojaba el agua de lluvia de todas las casas (a las que llamaremos unidades habitacionales). Todas tenían paredes y pisos recubiertos de una pasta, denominada estuco, compuesta de cal y otros agregados en forma de polvo que permitían darle un acabado firme y fino, apto para poder decorarla con pinturas y, algo muy importante, la propia cal funcionaba como desinfectante natural, limitando así las posibilidades de que las enfermedades infecciosas se propagaran y se pudieran convertir en epidemias.

El control que Teotihuacan tenía sobre las minas de obsidiana de la zona llevó no sólo a su explotación, sino además a que en la ciudad existiera gran cantidad de talleres donde se manufacturaba este vidrio volcánico, convirtiéndola en instrumentos y objetos 
que se adquirían en toda Mesoamérica, derivando en importantes beneficios económicos que permitieron el intercambio por todo tipo de materiales, incluidas materias primas para la fabricación de artículos de lujo. Por otro lado, se tenía también la posesión de las minas de cal, lo que apoyó el esquema constructivo teotihuacano. Así, el trabajo con la obsidiana y el estuco, por decir lo menos, requería de instrumentos de diversos tipos: de hueso, de madera, de pedernal, y así, poco a poco esta urbe se transformó en un importante centro de desarrollo artesanal, desde quienes trabajaban el estuco hasta pintores que decoraban las paredes y desde trabajadores de talleres de cerámica hasta artesanos especialistas. Se sabe que incluso existieron centros de enseñanza de diferentes grupos, por ejemplo de los sacerdotes.

A la par de la obsidiana, las minas de cal y su control, tuvieron repercusión en el modo de construcción de Teotihuacan. Toda la ciudad fue estucada y pintada, lo que requirió de gran cantidad de mano de obra y de energía, quemando mucha leña para transformar la cal.

Todo este sistema productivo y de desarrollo convirtió a Teotihuacan en una ciudad que rápidamente extendió su poder e influencia en todas direcciones. Sabemos que en el interior de la ciudad existían barrios, sectores, donde vivían grupos de diferente origen étnico cuyo propósito era mantener las relaciones y comunicación entre el gobierno central y sus regiones de procedencia. Por otro lado tenemos objetos de origen teotihuacano descubiertos en Centroamérica o grabados en los que aparecen reuniones entre dignatarios teotihuacanos y gobernantes mayas.

Este desarrollo alcanzó su más alto nivel en Xolalpan, la siguiente fase, momento en que también la ciudad alcanza su mayor extensión y tamaño de población, alrededor de 150,000 habitantes, con lo que, según se piensa, pasó a ser, en ese momento, una de las mayores ciudades del mundo (Figura 4). 
No obstante el gran desarrollo económico y social, en el interior de la ciudad existían fuertes tensiones sociales, mismas que derivaron en momentos de violencia al final del periodo y aunque el control fue recuperado, ciertamente su poderío se vio mermado al grado de que el gobierno central prácticamente desapareció y el control de los recursos poco a poco quedó en manos de otros pueblos. Este es el esquema que aparentemente dominó en la última fase, denominada Metepec, la cual marca también el final de esta cultura como tal.

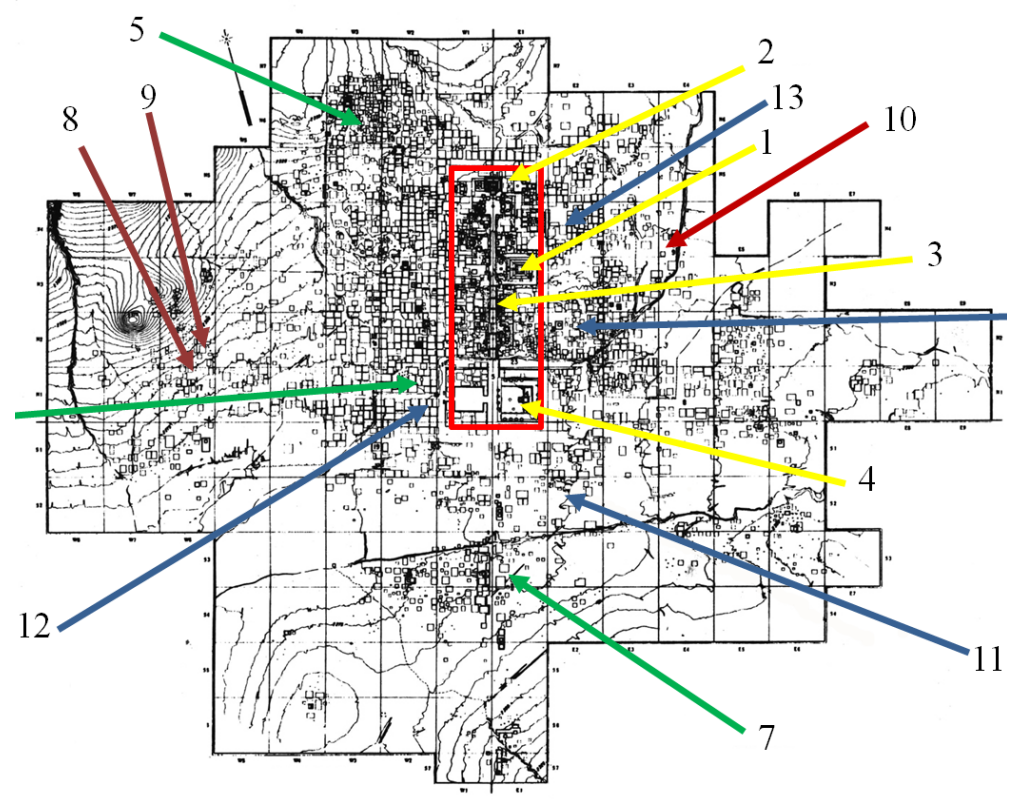

\footnotetext{
Clave:

Centro ceremonial $\Longrightarrow$ Construcciones principales

1. Pirámide del Sol

2. Pirámide de la Luna

3. Calzada de los Muertos

4. Ciudadela y Templo de Quetzalcoatl

$\Longrightarrow$ Unidades
}

\begin{tabular}{|c|c|c|}
\hline \multicolumn{3}{|l|}{$\Longrightarrow$ Unidades } \\
\hline cionales & 8 Oахаяu & opan \\
\hline 6. Tetitla & 9. de Occidente & 12. La Ventilla \\
\hline 7. Tlajinga 33 & 10. de los Comerciantes & $\begin{array}{l}\text { 13. San Sebastián Xolalpan } \\
\text { 14. San Francisco Mazapa }\end{array}$ \\
\hline
\end{tabular}

de Occidente

Figura 4. La ciudad de Teotihuacan en su máxima extensión y sitios descritos y empleados en el libro. El cuadro rojo delimita el centro ceremonial que es el principal espacio turístico visitable en la actualidad. (Adaptado por Raúl Valadez de Millon 1973). 
Ya desde los últimos momentos de existencia de Teotihuacan, nuevos grupos llegaron al valle y paulatinamente fueron ocupando unidades habitacionales, que quedaban en pie, destruyendo templos en busca de tesoros, dejando al abandono las grandes pirámides, ignorando los beneficios de la infraestructura, transformando la otrora imponente ciudad en conjuntos de construcciones derruidas, triste evidencia de una ciudad que alguna vez dominó todo el mundo mesoamericano conocido.

\section{La vída del teotíhuacano y su alímentación}

Frente a una historia tan interesante y compleja tenemos aspectos de enorme relevancia y que no siempre les damos la debida importancia, por ejemplo la forma como se vivía al interior de una unidad habitacional. Es costumbre enfocar siempre nuestro interés en las grandes construcciones, en las pirámides, sin tener en cuenta que esos monumentos fueron construidos por personas a las que vale la pena conocer. De manera más específica es un tema de particular relevancia saber cómo vivía la gente común al interior de una ciudad como esta y cuáles fueron sus rutinas.

Pero sin duda uno de los principales aspectos dentro del estudio de la "cotidianeidad" es la alimentación, desde saber cuáles eran sus principales alimentos hasta determinar si todos los teotihuacanos comían igual y, si no era así, reconocer las circunstancias que llevaban a esa diferenciación alimentaria y si ello tenía como consecuencia condiciones de salud distintas.

\section{La ciencía acepta el reto}

Desde que los antropólogos físicos hicieron los primeros estudios con los restos humanos descubiertos se fueron encontrando evidencias que dejaban ver, que tan bien o mal alimentado había estado ese individuo. No obstante al paso de los años se han desarrollado 
diversas disciplinas y métodos que permiten obtener mucha más información al respecto, no sólo de los individuos como tales, sino también de los restos de animales y plantas que pueden asociarse con lo alimentario, de los espacios y objetos cuya evidencia indica que algo relacionado con la comida quedó ahí o bien de relaciones comerciales o de intercambio con otras regiones, dentro de las cuales se incluían alimentos como tales.

En estos estudios participan diversas disciplinas: la química, la física, la zoología, la botánica, la palinología, la osteología, la arqueología, la geología, todas ellas con metodologías adecuadas para responder al reto: saber lo más posible acerca de lo que era la alimentación al interior de la ciudad de Teotihuacan.

Lista de las obras empleadas en la elaboración del capitulo $6,8,12,13,15,16,17,22,25,26,27,28,29,40,42$.

\section{Páginas electrónicas relacionadas con imágenes}

Quarto de Jade (06/02/2010) Nagual. Un romance gráfico, https:// quartodejade.wordpress.com/2010/02/06/nagual/, (consultado el 7 de agosto de 2017). 
Si regresáramos al pasado, ¿qué querríamos conocer respecto de la alimentación de los teotíhuacanos?

Si pudiéramos viajar al pasado y encontrarnos en tiempos teotihuacanos, ¿qué es lo que más nos interesaría saber respecto de su alimentación?

Si alguno de nosotros caminara sobre sus calles sin duda no tardaría en preguntarse qué tipo de alimentos podría encontrar, sobre todo si al paso de las horas la sensación de hambre empieza a manifestarse. Como mexicanos, pronto empezaríamos a pensar en tortillas, frijoles, chile. ¿Estos alimentos eran habituales en Teotihuacan? ¿Qué otros habría?

Siguiendo con nuestro camino, pensaríamos también no sólo en los alimentos, sino en dónde podríamos encontrarlos. Ciertamente al interior de una casa es seguro que habría, pero ¿sólo ahí? Tratándose de una ciudad de más de 100,000 habitantes, con gran cantidad de personas que hacían sus jornadas diarias de trabajo en talleres, ¿iban a su casa a comer?, ¿llevaban su comida o alguien les proporcionaba su alimento diario? Y, algo muy importante, ¿̇su alimento lo obtenían ellos mismos de sus propias milpas y criaderos o había un sistema organizado de productores de alimentos y consumidores con espacios públicos de comercio a manera de mercados?

En tercer lugar, y suponiendo que de pronto fuera posible ubicar un lugar donde tienen alimentos, ¿Cómo y dónde se preparaban? ¿Qué instrumentos habría para ello? ¿Cómo se consumían? Además, muy pronto pensaríamos ¿qué bebían? ¿Disponían sólo de agua o disponían de bebidas más elaboradas?

Por último, y ya después de haber cubierto el objetivo de comer, no sería extraño que se comentara si esos alimentos eran lo habitual, si todos los teotihuacanos se alimentaban de lo 
mismo, si había quienes lo hacían más o mejor y por qué; si sería como en nuestra época, donde hay gente que tiene acceso a toda la comida que quiera y quien sólo puede emplear algunos alimentos. La respuesta a estas preguntas las consideraríamos muy relevantes para saber cómo evaluar la experiencia vivida, sobre todo si era el primero de varios días en los que comeríamos como un teotihuacano. 
21

COMO SE ESTUDIA

lo antíguo 


\section{La interdisciplina: una ventana para ver el pasado}

T as investigaciones que podemos realizar hoy en día alrededor de los sitios arqueológicos, y los objetos recuperados, son enormemente diversas, involucrando múltiples ciencias y al final nos proporcionan tanta información que pareciera posible ver con nuestros propios ojos toda la historia de una persona, un objeto, una construcción o un organismo, justo como si estuviéramos en el momento en que era un lugar funcional y activo. El trabajo conjunto y coordinado de todas estas ciencias, aportando cada quien sus conocimientos alrededor de los objetos estudiados para llegar a una visión integrada es conocido con el nombre de interdisciplina. Con ella es posible crear obras como la presente y ver el pasado como si estuviéramos sentados en una sala de cine o en nuestro lugar favorito.

\section{Laboratoríos de ciencias aplicadas}

Quienes elaboramos este libro trabajamos en laboratorios del Instituto de Investigaciones Antropológicas, Instituto de Geología e Instituto de Geofísica de la Universidad Nacional Autónoma de México.

A través de ciencias diversas estudiamos materiales, principalmente de procedencia arqueológica, con el propósito de entender la razón de su presencia y reconstruir eventos del pasado y su relevancia a nivel cultural. Los laboratorios en cuestión son:

Antropología forense.

Antropología genética.

Fitolitos

Paleozoología

Paleobotánica y Paleoambiente

Prospección arqueológica 
Universitario de Radiocarbono

Si entras a internet y utilizas la siguiente dirección:

http://www.iia.unam.mx/publicaciones/detalles.php?clave=489D

Podrás descargar gratuitamente el libro Viaje al inframundo. Las Ciencias y la Muerte, en el cual se explica la forma como cada laboratorio dispone de esquemas de trabajo y técnicas apropiadas para alcanzar el objetivo señalado. Te recomendamos que lo descargues y así dispongas de dos obras en las que se muestra esta parte del quehacer científico de México.

\section{Un interesante campo de estudio: la osteología humana y las enfermedades causadas por desnutrición}

Sin duda un aspecto fundamental en estudios relacionados con la alimentación es reconocer cómo se alimentaba la gente, aspecto que se cubre a través del estudio de los huesos, es decir, de la osteología humana.

Para conocer el estado de salud de un individuo antiguo nos basamos fundamentalmente en sus restos, es decir, huesos y dientes. Dicho estado de salud, derivado en buena medida por la calidad de su alimentación, involucra diversas reacciones fisiológicas de regulación que mantienen el equilibrio del organismo y a este proceso se le denomina estrés. La llegada de la agricultura al México antiguo permitió mejorar las condiciones de vida de las personas, pero la estratificación social, la especialización de actividades y el aumento de la densidad poblacional derivó al paso del tiempo en la disminución de la calidad de la dieta, el racionamiento de los alimentos y ello frecuentemente derivaba en enfermedades diversas.

Para reconocer la relación entre los niveles de salud y las condiciones socioeconómicas, eventos históricos y culturales para distintos sitios 
y periodos se toman en cuenta como indicadores la demografía y mortalidad, condiciones nutricionales, reacciones infecciosas en el periostio ${ }^{2}$, patologías dentales, enfermedades articulares degenerativas en el esqueleto, desgaste dental y traumatismos.

Es importante aclarar que el estrés causado por las condiciones de salud deja marca permanente en el hueso, lo que permite registrar la historia de vida del individuo. Estos indicadores pueden ser reconocidos y evaluados en función del esfuerzo que hizo el organismo por superar la tensión fisiológica por largo tiempo y también podemos reconocer la edad en la que el individuo sufrió deficiencias en su salud y, en algunos casos, relacionar estas "marcas" con enfermedades específicas.

La nutrición es la suma de procesos a través de los cuales un organismo obtiene y utiliza sustancias alimentarias que incluyen la ingestión, digestión y absorción de los nutrientes; permiten el crecimiento, conservan las funciones corporales, reparan tejidos y generan energía. Una nutrición adecuada contiene calorías para aportar energía, proteínas para constituir tejidos y para el desarrollo de funciones celulares, así como vitaminas, minerales y agua para cubrir las necesidades específicas de los carbohidratos y proteínas. La cantidad varía en cada individuo según el sexo, edad, complexión corporal, temperatura ambiente, intensidad y tipo de actividad física. La actividad física y las enfermedades son factores que intervienen en el estado nutricional, ya que el organismo utiliza los recursos proteicos y energéticos para crecer o para la recuperación de otras funciones en caso de enfermedad.

El crecimiento se considera inespecífico y acumulativo e implica desigualdad social respecto a las condiciones de vida. Cuando no hay diferencia del crecimiento en una población, puede hablarse de igualdad respecto al acceso a los recursos, sea en sentido positivo o negativo. La valoración del crecimiento incluye la construcción de

2 Membrana fibrosa y resistente con terminaciones nerviosas y red sanguínea que recubre los huesos, proporcionándoles sensibilidad y apoyando su nutrición. 
curvas estadísticas basadas en las medidas de longitud y ancho de huesos largos para cada categoría de edad. En los adultos, la longitud de los huesos largos puede reflejar parte de la carga genética; en cambio el espesor, ancho y estructura histológica pueden reflejar patrones de actividad metabólica y perturbación fisiológica. En el caso de subnutrición en los niños, lo primero en alterarse es el ritmo, dando lugar a un crecimiento lento. En la cuenca de México, en tiempos teotihuacanos y posteriores la estatura promedio de los varones fue de $1.60 \mathrm{~m}$ a $1.65 \mathrm{~m}$ y en las mujeres de $1.46 \mathrm{~m}$ a $1.53 \mathrm{~m}$.

Otro marcador que se emplea para reconocer las condiciones nutricionales es la hipoplasia en el esmalte. Esta consiste en una deficiencia en el espesor del esmalte dental que se presenta en forma de líneas. Las anomalías se deben a la herencia, traumas localizados o alteraciones metabólicas generalizadas. Los defectos del esmalte son muy sensibles a los cambios metabólicos y fisiológicos y se consideran interrelacionados con el estatus socioeconómico, es decir, con las condiciones de vida y calidad alimentaria.

La deficiencia nutricional proteica y vitamínica que incluyen hierro es llamada anemia y es común entre grupos de escasos recursos, ancianos y personas con requerimientos nutricionales mayores. Se caracteriza por la concentración subnormal de hemoglobina en la sangre, y en el tejido óseo se detecta a través de una lesión (de apariencia porosa) que se distribuye simétricamente en el cráneo, básicamente en las órbitas, el hueso frontal, los parietales, el occipital, así como en los extremos de los huesos largos cuando se incrementan de células de la sangre en las cavidades de la médula ósea, este tipo de anomalía es conocida con el nombre de hiperostosis porótica.

La hiperostosis porótica resulta de episodios durante la infancia en que no se completa el crecimiento del hueso. No obstante se ha demostrado que la deficiencia de hierro no siempre actúa en detrimento de la salud, sino que puede funcionar como una defensa del organismo contra cierto tipo de bacterias que dependen del 
hierro; eso explicaría por qué los individuos de sitios arqueológicos quienes parecen tener dietas ricas en hierro y aún en proteínas, presentan grandes niveles de hiperostosis, ya que viven en áreas donde hay muchos patógenos (por ejemplo sitios de tierras bajas y áreas tropicales).

\section{Otros campos de investigación de relevancia para la alimentación en tíempos antiguos: isótopos y elementos traza}

En años recientes se han desarrollado líneas de investigación cuyo objetivo es conocer determinados aspectos sobre la alimentación de un individuo antiguo a través de la química del hueso (Figura 5). Uno de ellos se basa en la cuantificación de isótopos ${ }^{3}$ de elementos como Carbono (C) y Nitrógeno (N). Estos elementos existen de forma natural en el ambiente, siendo el suelo el espacio con mayor abundancia. El sedimento es la fuente de nitrógeno para las plantas, mientras que al carbono lo absorben de la atmósfera a través de la fotosíntesis. Se ha visto que en el caso del carbono, durante la fotosíntesis, los vegetales llegan a fijar los isótopos de $13 \mathrm{C}$ de forma diferencial, derivando en concentraciones distintas a la de la atmósfera y que dependen del tipo de fotosíntesis que realizan. Para el caso de las especies de importancia alimentaria, las diferencias en la fotosíntesis permite dividirlas en tres grupos con concentraciones de $13 \mathrm{C}$ particulares: grupo C3, donde quedan plantas de bosques, árboles frutales, frijol y otras leguminosas; grupo $\mathrm{C} 4$, que incluye por ejemplo al maíz, el amaranto, la verdolaga y por último están las plantas CAM, donde se incluyen cactáceas como el nopal y el maguey (Figura 5A).

\footnotetext{
3 Un átomo de un elemento determinado se caracteriza por poseer en su núcleo un número constante de partículas positivas (protones) y variable de neutras (neutrones), así como otras negativas (electrones) que se ubican fuera del núcleo, así, en el caso del carbono, el elemento más relevante en la constitución de los seres vivos, su átomo posee seis protones (número al que llamamos "número atómico") y, en la mayoría de los casos, seis neutrones (la suma de protones y neutrones, que sería igual a doce, 12C, se denomina "masa atómica"), pero también hay átomos de C con siete neutrones (13C) e incluso ocho (14C), todos ellos con masa diferente y son conocidos como isótopos.
} 

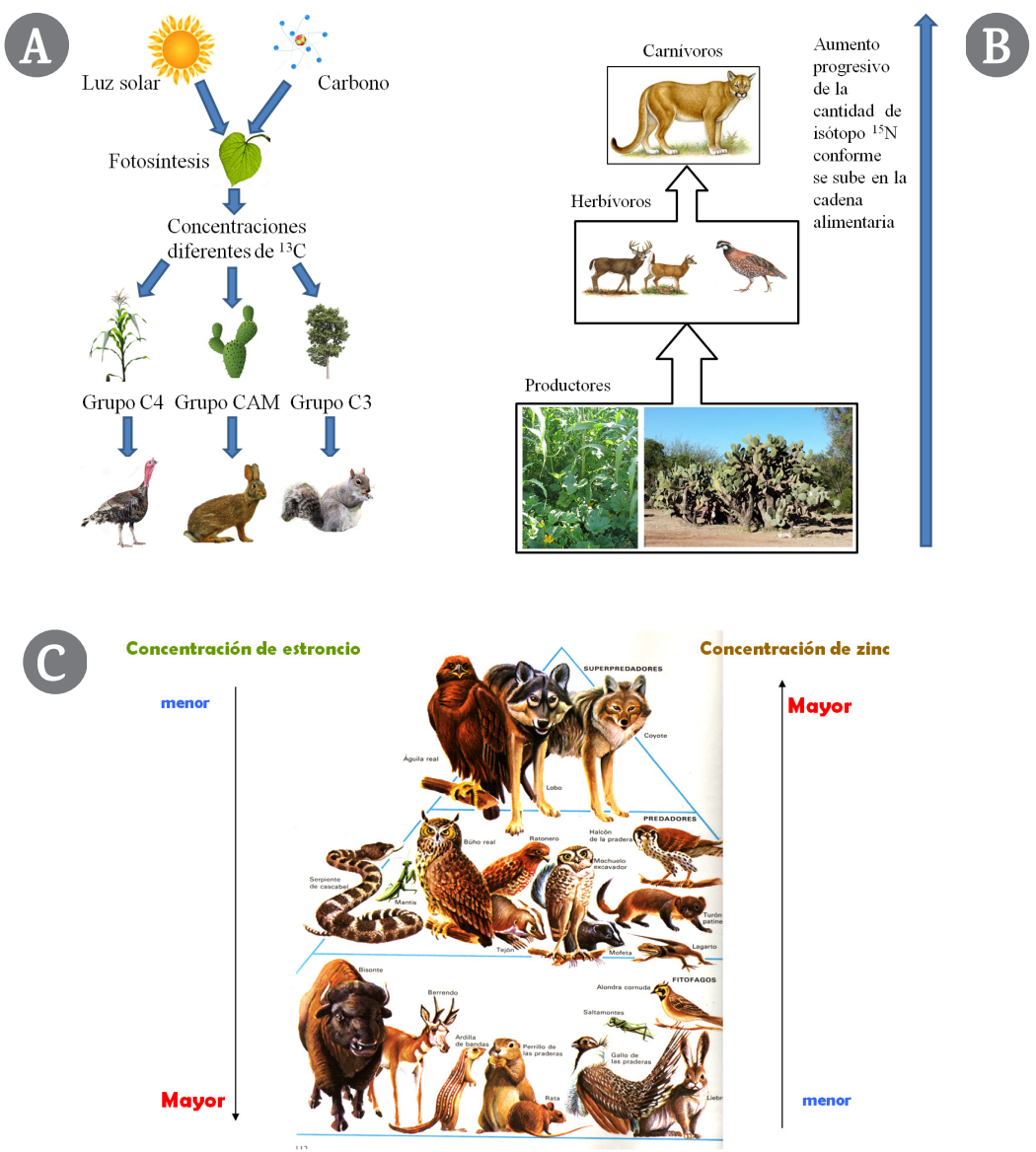

Figura 5. Diagramas que muestran las bases biológicas para el uso de isótopos de Carbono y Nitrógeno y elementos traza para determinar patrones alimentarios de individuos antiguos. En el caso del isótopo de Carbono, 13C (A), la fotosíntesis en diferentes grupos de plantas promueve distintas concentraciones que pasan de un nivel trófico al siguiente. En el caso del isótopo de Nitrógeno, 15N (B), éste pasa de un organismo a otro a través de la cadena alimentaria, aumentando simultáneamente su presencia. En los elementos traza (C), su concentración se mueve acorde a la pirámide alimentaria, en algunos casos aumentando (Zn), y en otros, disminuyendo (Sr). (Elaboración o adaptación de las figuras Raúl Valadez). 
La proporción de isótopos estables no varía durante el tiempo de vida de la planta e incluso, cuando ésta es comida por un animal, las concentraciones del 13C se mantienen en los tejidos, huesos y dientes incluidos, dando así lugar a animales y personas con concentraciones de isótopos características de acuerdo con los vegetales que fueron la base de la cadena alimentaria.

¿Y a qué nos lleva todo esto? En función de lo comentado es posible reconocer cuál fue la fuente de alimento vegetal predominante para cada persona cuantificando la concentración de $13 \mathrm{C}$ en el hueso y el esmalte de los dientes, por ejemplo si era el maíz su alimento principal, si consumían muchos nopales, frutos, frijol y demás.

En el caso del otro isótopo, el 15N, éste es también absorbido por las plantas y empleado en la elaboración de proteínas (Figura 5B) y, como en el caso anterior, al momento en que un animal come a la planta, se lleva también al $15 \mathrm{~N}$.

Ya en el herbívoro, el nitrógeno se emplea, de igual forma, en la elaboración de aminoácidos, y durante los procesos de excreción sale con la orina, sin embargo en este momento el nitrógeno común $(14 \mathrm{~N})$ es el que es expulsado con mayor frecuencia a diferencia del $15 \mathrm{~N}$, haciendo que al paso del tiempo su concentración aumente. Posteriormente, cuando este animal es comido, el 15N, en su versión más concentrada, es asimilado por el carnívoro, haciendo así que conforme pasamos de un nivel a otro en la cadena alimentaria, los valores de $15 \mathrm{~N}$ sean mayores. Gracias a esto es posible saber si una persona tuvo una dieta basada en plantas o en qué medida la carne fue parte importante en su alimentación (Figura 5B).

El segundo campo de investigación, al que llamamos "elementos traza”, parte de principios similares a lo que hemos visto con el Nitrógeno (Figura 5C). Llamamos elementos traza a un grupo, formado por el Estroncio (Sr), el Zinc (Zn) o el Bario (Ba), que encontramos en el hueso en cantidades muy pequeñas y se mantienen de forma inercial, es decir, sin función alguna en el hueso. ¿De dónde llegan? 
Como en los dos casos anteriores, el punto de origen es el ambiente, en especial el suelo, y la absorción de estos por las plantas. En el caso del Sr, la planta lo absorbe y queda en sus tejidos, cuando un herbívoro la come lo toma también y poco a poco se va acumulando en su cuerpo, aunque nunca alcanza los niveles de los vegetales. Posteriormente al herbívoro se lo come el carnívoro y el proceso se repite, pero de nuevo no se alcanzan las concentraciones del nivel trófico anterior. De este modo, y con ayuda de patrones de referencia, es posible saber si una persona tuvo una alimentación más rica en plantas o carne.

La contraparte del Sr lo tenemos con el Zn. Este elemento se mueve de manera similar a través de la cadena alimentaria, pero se ha visto que interviene en la formación de proteínas, por lo que entre más carne ha consumido el animal, o el hombre, en su vida, más alta es su concentración.

En el caso del Ba, su relevancia es que se trata de un elemento asociado con los ambientes marinos, de forma que su concentración depende de que tan rica ha sido la dieta de un individuo con alimentos de este tipo.

\section{Preguntas generadoras de investígación y formas de responderlas}

Siguiendo con nuestro tema, ¿de qué forma participa cada laboratorio, cada disciplina, en un tema como el presente?

Para abordar esto veamos la Figura 6. Su centro es el tema clave: alimentación en Teotihuacan, objetivo del cual se desprenden diversas preguntas que formulamos al imaginar que estábamos caminando en Teotihuacan. Todas se encuentran en un anillo alrededor del interés principal pues se generaron a partir de éste.

Para responder a las siete preguntas formuladas necesitamos saber qué tipo de evidencias nos sirven, qué objetos o materiales pueden aportarnos mejor información al respecto; por ejemplo, para saber 
qué comían requerimos de restos de organismos y evidencias de que se emplearon con este fin. También pueden emplearse pinturas 0 figuras donde aparezcan escenas de comidas o de plantas y animales que se están comiendo o preparando para ello. Para la pregunta de si todos comían igual se requiere saber más bien el estudio de los restos humanos para conocer su estado nutricional y patrón alimentario. Este nivel de la investigación está incluido en el segundo anillo.

Por último tenemos las disciplinas que tienen en sus manos los métodos, esquemas de trabajo y bases teóricas para realizar el estudio de cada tipo de evidencias, quedando todas ellas en la parte externa de la Figura 6. De esta forma, siendo nuestro objetivo de estudio la alimentación en Teotihuacan, una de las preguntas, ¿cómo preparaban su comida?, requiere de la búsqueda de rastros de calor, del estudio de muebles e instrumentos para cocinar y de las evidencias de manipulación en los restos animales y vegetales, por ejemplo marcas de corte y de cocción; al respecto, las disciplinas (y laboratorios por añadidura) que se involucrarían serían prospección arqueológica, paleoetnobotánica, fitolitos ${ }^{4}$ y paleozoología (Figura 6).

Si este diagrama lo vemos en sentido opuesto, es decir de afuera hacia adentro, lo que tenemos es un conjunto de áreas de investigación que trabajan al unísono diversos materiales para responder a ciertas preguntas y así llegar al tema central, pero con la perspectiva de integrar todos los saberes en un solo paquete organizado y esto es precisamente lo que corresponde a un estudio interdisciplinario.

\section{Lista de las obras empleadas en la elaboración del capitulo}

$4,7,8.9,10,11,15,21,23,24,27,28,29,40,42,43,44,46,48$.

4 El término fitolito se utiliza para hacer referencia a cristales microscópicos de sílice que se forman al interior de las células vegetales, adquiriendo formas características. Cuando la planta muere dichos cristales se conservan en el lugar y con ellos podemos determinar que planta fue la que se utilizó. 


\section{Dírecciones electrónicas de imágenes de Figura 5:}

Losecosistemas, https://www.biografiasyvidas.com/tema/ecosistema. htm

http://axochiapancultural.blogspot.mx/2016/04/la-boda-tradicionalel-huentle-y-el.html http://lascosasdejuampa1.blogspot.mx/2014/07/ imagenes-para-photoscape-photoshop-y_13.html

http://www.leroymerlin.es/fp/13999244/arbol-de-ano-y-medioaguacate-variedad-hass

http://vectoriteca.blogspot.mx/2013/08/nopal-vectores.html

http://www.hermanos-gomez.es/productos/caza/conejo-de-monte/

https://www.flickr.com/photos/lamerie/7784306434

https://naturalhistory.si.edu/mna/image_info.cfm?species_id=231

http://www.hbw.com/species/northern-bobwhite-colinusvirginianus

http://leyendasmexicanas.org.mx/el-puma-recibe-una-leccion/

https://www.flickr.com/photos/lucynieto/13961680697 


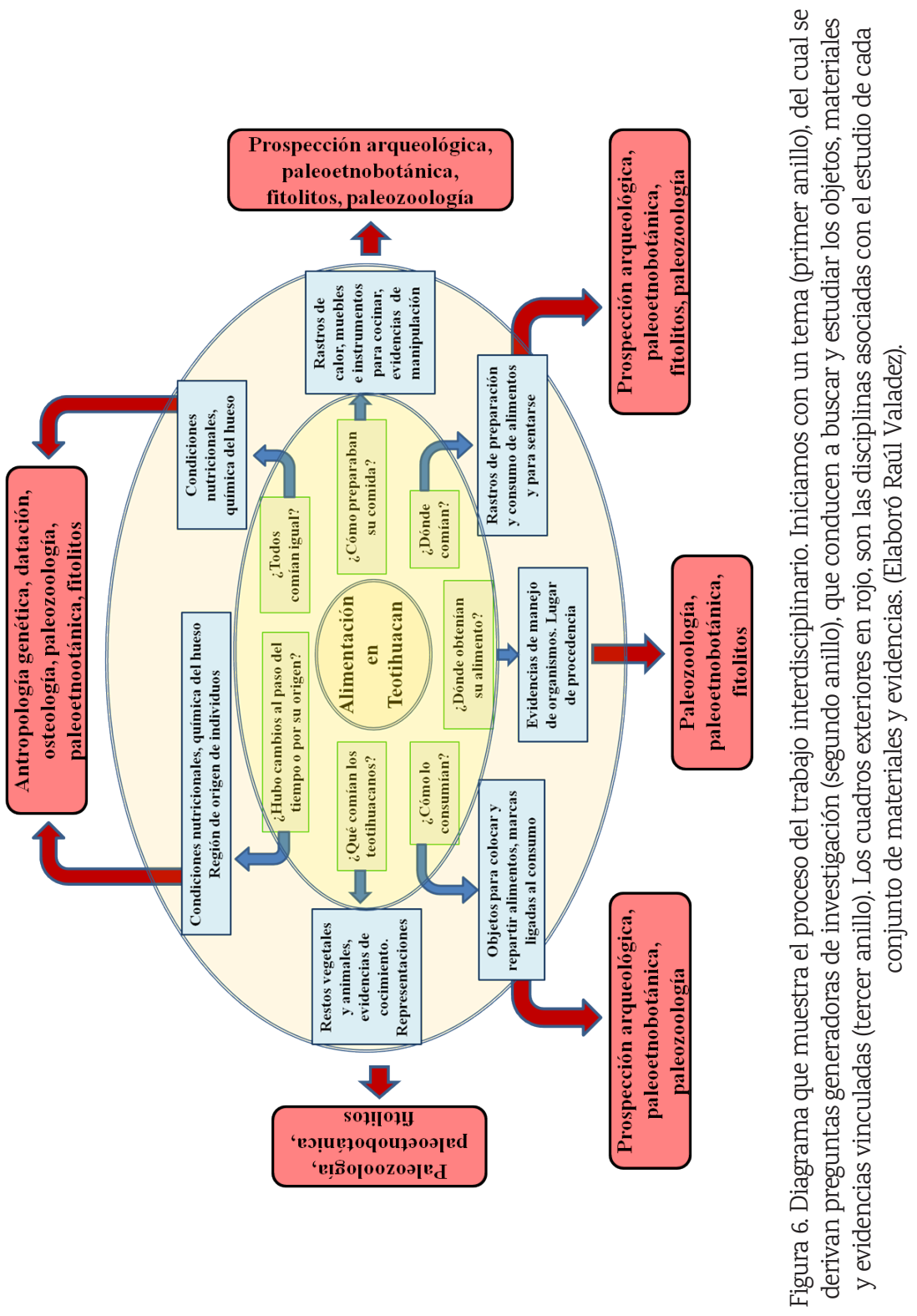




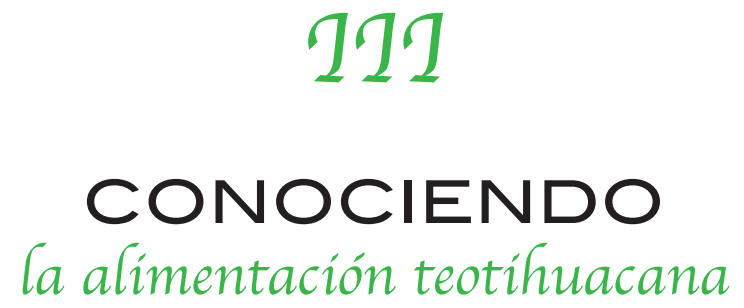




\section{Explorando una casa teotínuacana a la fora de la comida}

T a época denominada Xolalpan es la que mejor conocemos para $\perp$ Teotihuacan en todos sentidos, ya que habiendo sido su momento de mayor esplendor, se dedicó buena parte del esfuerzo económico en la renovación de edificios, lo que implicó la destrucción de lo anterior $\mathrm{y}$, al ser la fase siguiente un periodo de decadencia, ya no existían recursos para construir espacios nuevos. Debido a ello mucha de la información que se presenta corresponderá al periodo Xolalpan, y cuando no sea así se aclarará.

En esta época, existían diversos tipos de construcciones, algunas, como las pirámides, eran de uso ritual; otras eran casas grandes, complejas, con paredes decoradas, con funciones administrativas o palacios de la élite y, por último, tenemos a las unidades habitacionales o conjuntos departamentales de la población en general (Figura 7).
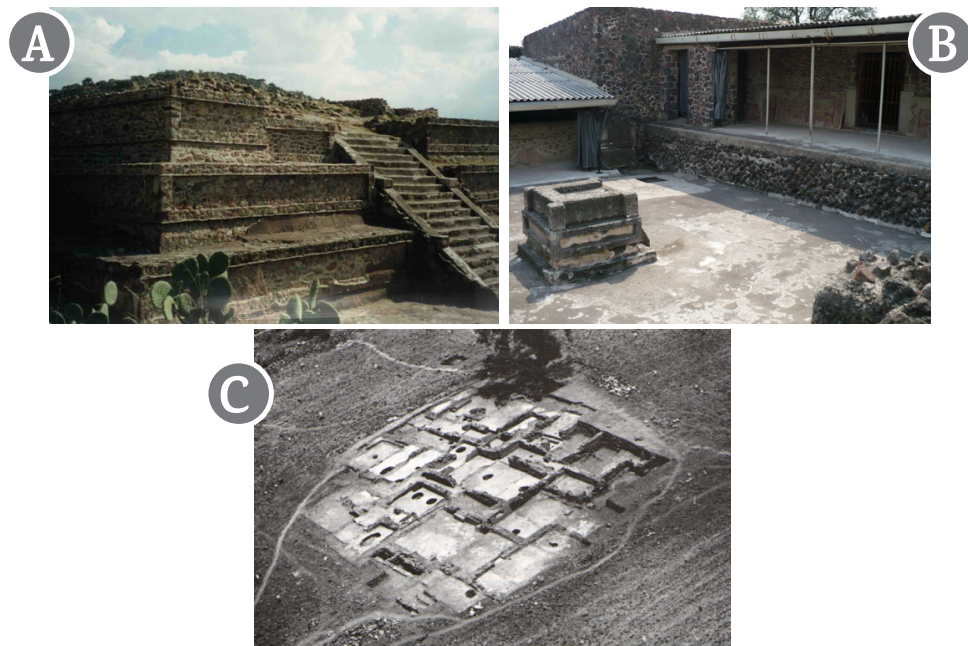

Figura 7. Ejemplos de estructuras arquitectónicas teotihuacanas. (A), basamento de templo en la Calzada de los Muertos; (B), patio principal de la unidad residencial de Tetitla; (C), vista aérea de unidad habitacional de Oztoyahualco. (Fotografías A y B de Raúl Valadez, fotografía C de Linda Manzanilla). 
Al momento de entrar a una unidad habitacional no de la clase gobernante, pero sí de gente acomodada como las que en el presente podemos visitar en la zona arqueológica, se pasa por un recibidor y se llega a una escalinata que conduce a un patio cuadrado, con un altar central (Figura 7B) rodeado de cuartos, uno de ellos de uso religioso, un templo, y los restantes para uso personal, sobre todo de los señores de la casa. Generalmente de las esquinas se derivan pasillos que llevan a otros cuartos o patios, donde se replica el esquema, pero con dimensiones menores y para un uso más doméstico y práctico.

Después de avanzar en nuestro recorrido, descubrimos que no existen estructuras colocadas de forma permanente en el piso de alguno de los cuartos que hubieran servido para hacer fuego y ahí elaborar la comida, ni tampoco fogones en alguno de los patios, de modo que necesariamente nos surge la pregunta ¿dónde elaboraban su comida?

Generalmente los pisos de una unidad habitacional como la indicada estaban cubiertos de estuco, detalle que le daba a estas casas un acabado tan fino como en nuestros días las paredes enyesadas y los pisos cubiertos de losetas, pero un pequeño inconveniente era que su uso continuo los desgastaba y siempre era posible que se mancharan por el derramamiento de sustancias diversas y qué decir de una fogata, simplemente hubiera destruido en poco tiempo al piso como tal. Como se indicó al inicio, una ventaja de estos acabados era que promovían las condiciones de higiene en más de una forma (desde la función de desinfectante natural de la cal hasta la necesidad de barrer y limpiar las paredes ante la visible acumulación de polvo, residuos diversos, telarañas y demás), por lo que su cuidado era indispensable, pero ello nos obliga a regresar al punto ¿cómo producir calor para elaborar el alimento sin estructuras de piedra y sin dañar los pisos?

La respuesta a ello se obtiene por dos medios, en primer lugar, de todo el universo de objetos recuperados en la ciudad los únicos hechos para contener el calor adecuado para transformar alimentos son anafres y braseros de barro (Figura 8). Sin duda el uso de leña no sería lógico ni apropiado, pero sí el carbón, ya que con él dispondríamos de 
suficiente calor sin la formación de humo y sin el riesgo de dañar el piso. En algunos casos aislados o también en espacios habitacionales de las épocas más tempranas de Teotihuacan hasta Tlamimilolpa, aparecen tlecuiles (hogueras en cajas de piedra) en patios. Esto significa que en el inicio, la comida se preparaba con leña, en estos lugares, pero conforme la ciudad creció y a partir de la fase Xolalpan las casas recubiertas de estuco se convirtieron en la norma, se pasó de un modelo al otro.

No obstante el gran cuidado invertido, al observar los pisos podemos constatar que en algunos cuartos hay espacios con manchas o de coloración ligeramente más oscura que el resto, de forma ovalada o irregular y que a veces podemos reconocer como tizne ${ }^{5}$ o bien enrojecido por la acción del calor. El estudio químico ha permitido determinar que estos cambios de coloración son también producto de temperaturas altas de los anafres, que afectaban esos espacios de manera continua.
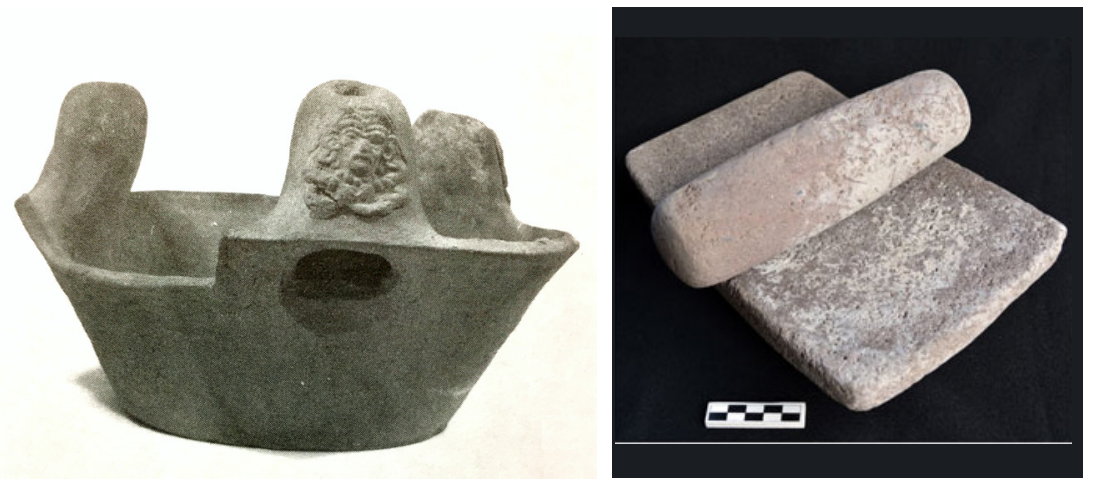

Figura 8. Brasero (A) y metate (B) teotihuacanos. (Fotografías tomadas de Rattray 2000 y Economía doméstica. http://sites.bu.edu/patt-es/investigacion/economia-domestica/)

Además de los braseros y anafres, hay otros instrumentos cuya presencia nos habla de la preparación del alimento y su

5 Ceniza con residuos orgánicos como grasas que se adhiera a las superficies de trastos o paredes. 
resguardo, por ejemplo metates, ollas, tapaplatos, ánforas (ollas de almacenamiento), aunque en muchos casos aparecen ya rotos, como fragmentos o entre la basura. Para responder a la duda de si un objeto descubierto en esas condiciones pudo haber tenido relación con el alimento, se tiene la opción de estudiar sus superficies con el microscopio y sus poros a nivel químico, buscando la presencia de residuos del tipo de proteínas, carbohidratos o lípidos, es decir, de sustancias orgánicas, y de esta forma asegurar que en su interior se vertieron alimentos, por ejemplo aguamiel. También, mediante la identificación de fitolitos o restos vegetales, podemos saber si en esos metates o recipientes se manipularon diversas plantas, a veces durante la elaboración del alimento o incluso para su resguardo, como sería en el caso de semillas, principalmente.

Un caso muy relevante es que hasta el presente no se ha descubierto un comal para tiempos teotihuacanos. Esto nos lleva a la posibilidad de que la gente jamás haya comido el maíz bajo la forma de tortillas, sin embargo la versatilidad de la masa elaborada con el grano nos deja muchas otras opciones que sin duda existían, tamales, gorditas, atole, totopos, sin olvidar a los elotes como tales, a las palomitas o a los esquites. La forma de preparación variaría, pero está firmemente demostrado que esta planta constituía el pilar de su dieta.

De esta forma el hallazgo de todo este conjunto de implementos nos dice que ciertamente en una unidad habitacional teotihuacana podemos reconocer donde se transformaba el alimento y cuáles instrumentos estuvieron asociados con ello. Ya una vez determinado esto la siguiente pregunta sería ¿dónde y cómo lo consumían?

Hasta ahora no se tiene información concreta que nos hable de muebles como sillas o mesas donde la gente comiera y si existieron no sobrevivieron al paso del tiempo (en tiempos posteriores se describe el uso de bancos de madera o de tule 
tejido), sin embargo sabemos que era algo frecuente el uso de petates para acomodarse alrededor de un espacio donde se preparaba y/o concentraba el alimento (Figura 9).

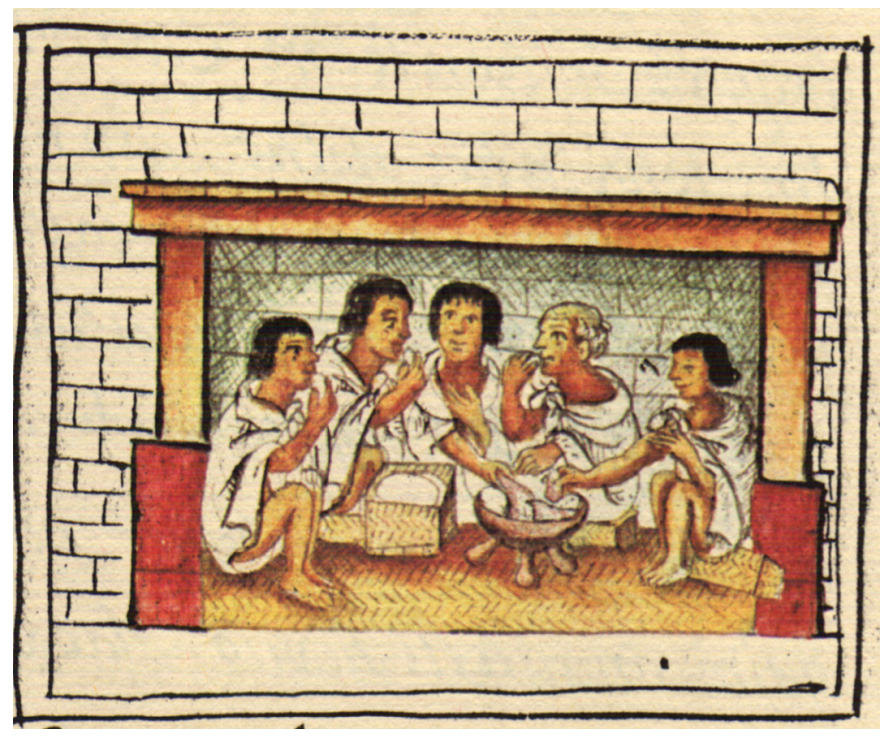

Figura 9. Imagen recreada de un momento de comida al interior de un cuarto que se muestra en el Códice Florentino, obra del siglo XVI escrito por Fray Bernardino de Sahagún, donde se describe la vida de los pueblos indígenas del centro en esa época, sobre todo de los mexicas. Aunque hay mil años de distancia cronológica entre Teotihuacan y México-Tenochtitlan, la escena es muy similar a lo que muestran los estudios químicos de los pisos de las unidades habitacionales teotihuacanas.

Por otro lado, junto con la información descrita acerca de huellas de calor encontradas en los pisos de estuco, también llegan a encontrarse manchas como derrames, así como otras que podrían ser coincidentes con espacios que la gente utilizaba para sentarse a la hora de comer. Normalmente la distancia entre el punto donde había calor y la zona de consumo es lo equivalente a un par de brazos y las manchas como derrames serían el resultado de accidentes durante el manejo del alimento que 
dejarían su huella, al ser absorbidas partículas microscópicas y líquidos por los poros del piso y ocurrir esto una y otra vez al paso de los años. Se han recuperado restos de platos, vasos, cajetes, copas y estos, más otros que muy probablemente se hicieron de madera o de otras partes duras de vegetales, por lo mismo no se conservaron, como cucharones por ejemplo, nos dice que cualquier casa teotihuacana estaba en posibilidad de disponer de una vajilla adecuada para cubrir las necesidades alimentarias de la familia.

Respecto del espacio físico empleado, aparentemente estos comedores se encontrarían en cuartos colocados junto a algún patio (Figuras 9 y 10), ya que así era más sencillo limpiar y deshacerse de cenizas y pequeños restos de alimento; de esta forma, es posible encontrar fragmentos de huesos cocidos de animales, de vegetales y esto, junto con las evidencias contenidas en metates y ollas, dejan abierta la puerta hacia el estudio de lo que sabemos sobre sus principales alimentos.

\section{Lista de las obras empleadas en la elaboración del capitulo}

$2,13,14,23,30,34,35,43,44$.

\section{Páginas electrónicas relacionadas con imágenes}

Anónimo

(2017) Urbanismo, organización de vecindarios y economía doméstica en el distrito de Tlajinga, Teotihuacan, México, Economía doméstica. http://sites.bu.edu/patt-es/investigacion/ economia-domestica/. (Consultado el 18 de julio de 2017). 


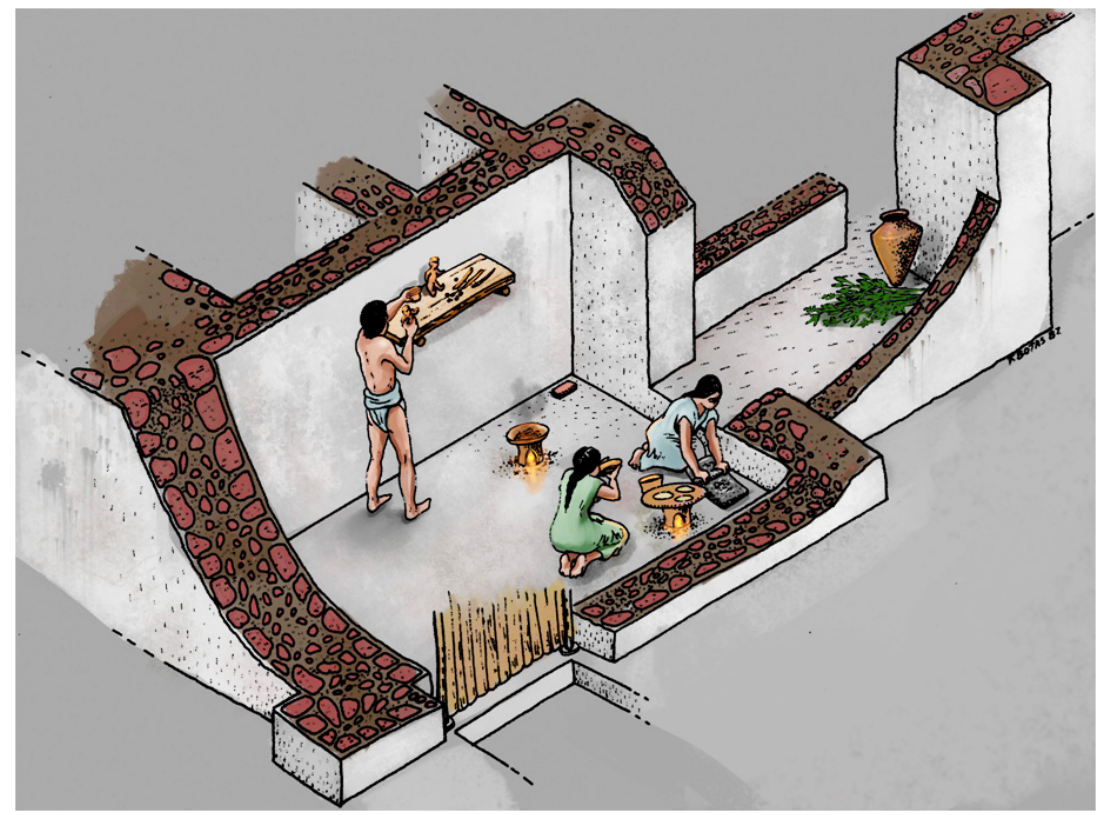

Figura 10. Reconstrucción hipotética derivada del estudio de la cocina de una unidad habitacional en el sector de Oztoyohualco, Teotihuacan (Figuras 4 y 7C). En el cuarto que aparece en primer término, denominado C3-4, las manchas rojizas y grises en el piso indicaron el punto donde se preparaba el alimento; la concentración de residuos químicos alrededor de la fuente de calor marcaron el espacio donde se consumía; una mano de metate y una vasija rota son ejemplos de instrumentos utilizados para su preparación y consumo; huesos de conejos, macrorrestos vegetales y fitolitos de maguey, maíz, calabaza y leguminosas (como podría ser el frijol), serían parte del alimento que se empleaba y un conjunto de sedimentos fibrosos y piezas diversas, sugirieron la presencia de una repisa de madera. Al lado derecho está el llamado C5 o despensa, en el cual se encontró una olla de almacenamiento y polen de zapote blanco. De C5 se pasaba a través de una abertura a C10, un traspatio con piso de tierra en el cual se encontraron gran cantidad de huesos de conejos y liebres, lo que permitió proponer que se trataba de animales cautivos de gran valor para estas personas, idea que se apoyó con el hallazgo de una escultura-altar de conejo en C33, cuarto ubicado en la parte este del conjunto. (Dibujo isométrico de Luis Barba, entintado por F. Botas y coloreado por F. Barba) 


\section{Mirando la despensa teotifuacana}

Hemos visto la forma como es posible reconocer restos de plantas y animales y además de que elementos disponemos para poder asociarlos con un uso alimentario. Con base en ello ¿qué tan grande podía ser una despensa teotihuacana?

Teotihuacan lleva casi un siglo de estudios arqueológicos, tiempo en el cual se han estudiado decenas de unidades habitacionales y otros edificios. En los últimos 50 años no solo se han excavado y reconstruido, sino se han formado colecciones de restos de plantas y de los animales descubiertos, permitiendo así formar amplios listados de alimentos posibles para los teotihuacanos.

En los Cuadros 2 y 3 tenemos la lista de plantas y animales reconocidas hasta el momento para Teotihuacan, muchos de ellos, sobre todo los vegetales, son en el presente parte de la dieta tradicional del mexicano y sin duda la lista era mucho mayor, por ejemplo a nivel frutas, pero lo importante es que esta lista proviene del propio contexto teotihuacano. Por el lado de los animales, sin duda el guajolote es la especie más vinculada con el alimento actual que tenemos ya en ese tiempo.

El primer aspecto interesante de los dos cuadros son los organismos que ya desde entonces se criaban o cultivaban. En el caso de las plantas la lista es muy grande, y ciertamente las unidades habitacionales teotihuacanas no disponían de grandes espacios abiertos que pudieran convertirse en huertos o milpas, por lo que debemos pensar que mucho del esfuerzo agrícola se realizaba en la periferia o en regiones aledañas. Para el caso de los animales, algunos podían mantenerse en las casas, como los conejos y liebres indicados en la sección anterior, y además estarían los guajolotes, que se aprovecharían a nivel carne y huevos. Sin embargo las cantidades que podían tenerse eran limitadas, por lo que es más probable que sólo se tuvieran los que se emplearían en el futuro inmediato. El caso 
de los perros es especial, pues los restos de muchos de ellos muestran marcas de navajas, de mordidas, de cocimiento, por lo que es seguro su empleo como alimento, sin embargo, como veremos más adelante, su uso involucraba también importantes aspectos religiosos.

Otro aspecto que salta a la vista es que también tenemos una larga lista de especies que se cazaban o colectaban en el campo (Figura 11), por ejemplo los venados y los armadillos y por el lado de las plantas, sin duda en casos como los nopales y magueyes se aprovecharían tanto los que crecían cultivados como los que vivían libremente, derivando de ellos productos como las tunas y el aguamiel, que se consumirían como fruto o como su producto fermentado, el pulque (Figura 12).

\begin{tabular}{|l|c|c|c|}
\hline \multicolumn{4}{|c|}{ Plantas } \\
\hline Nombre & Cultivada & Silvestre & Foránea \\
\hline Amaranto & $\mathrm{x}$ & $\mathrm{x}$ & \\
\hline Huauhtzontle & $\mathrm{x}$ & $\mathrm{x}$ & \\
\hline Epazote & $\mathrm{x}$ & $\mathrm{x}$ & \\
\hline Ciruela & $\mathrm{x}$ & $\mathrm{x}$ & \\
\hline Girasol & $\mathrm{x}$ & & \\
\hline Calabacita & $\mathrm{x}$ & $\mathrm{x}$ & \\
\hline Frijol & $\mathrm{x}$ & & \\
\hline Chia & & $\mathrm{x}$ & \\
\hline Aguacate & $\mathrm{x}$ & $\mathrm{x}$ & \\
\hline Maíz & $\mathrm{x}$ & $\mathrm{x}$ & \\
\hline Verdolaga & $\mathrm{x}$ & $\mathrm{x}$ & \\
\hline Tejocote & $\mathrm{x}$ & $\mathrm{x}$ & \\
\hline Capulín & & $\mathrm{x}$ & \\
\hline Chile & $\mathrm{x}$ & $\mathrm{x}$ & \\
\hline Xaltomata & $\mathrm{x}$ & $\mathrm{x}$ & \\
\hline Tomate verde & $\mathrm{x}$ & $\mathrm{x}$ & \\
\hline Nopal (y tuna) & & & \\
\hline Maguey & & $\mathrm{x}$ & \\
\hline Romerito & & & \\
\hline Jícama & & & \\
\hline Guayaba & & & \\
\hline & & & \\
\hline & & & \\
\hline
\end{tabular}

Cuadro 2. Plantas descubiertas en Teotihuacan relacionadas con el alimento. 


\begin{tabular}{|c|c|c|c|}
\hline \multicolumn{4}{|c|}{ Animales } \\
\hline Nombre & Doméstico & Silvestre & Foránea \\
\hline Tlacuache & & $\mathrm{x}$ & \\
\hline Armadillo & & $\mathrm{x}$ & \\
\hline Conejos (tres especies) & $\mathrm{x}^{*}$ & $\mathrm{x}$ & \\
\hline Liebres (dos especies) & $\mathrm{x}^{*}$ & $\mathrm{x}$ & \\
\hline Ardillas (dos especies) & & $\mathrm{x}$ & \\
\hline Ardillón & & $\mathrm{x}$ & \\
\hline Tuza & & $\mathrm{x}$ & \\
\hline Rata silvestre & & $\mathrm{x}$ & \\
\hline Perro & $\mathrm{x}$ & & \\
\hline Pecarí & & $\mathrm{x}$ & \\
\hline Venado cola blanca & & $\mathrm{x}$ & \\
\hline Venado cabrito & & & $\mathrm{x}$ \\
\hline Berrendo & & $\mathrm{x}$ & \\
\hline Patos (varias especies) & & $\mathrm{x}$ & \\
\hline Garzas & & $\mathrm{x}$ & \\
\hline Otras aves lacustres & & $\mathrm{x}$ & \\
\hline Codornices (tres especies) & & & \\
\hline Guajolote & $\mathrm{x}$ & & \\
\hline Palomas & & $\mathrm{x}$ & \\
\hline Tortugas casquito & & $\mathrm{x}$ & \\
\hline Tortugas japonesas & & & $\mathrm{x}$ \\
\hline Serpientes diversas & & $\mathrm{x}$ & \\
\hline Lagartos diversos & & $\mathrm{x}$ & \\
\hline Ranas, renacuajos & & $\mathrm{x}$ & \\
\hline Charales & & $\mathrm{x}$ & \\
\hline Pez bobo & & & $\mathrm{x}$ \\
\hline Mojarras & & & $\mathrm{x}$ \\
\hline Robalos & & & $\mathrm{x}$ \\
\hline Huachinangos & & & $\mathrm{x}$ \\
\hline Sardinas & & & $\mathrm{x}$ \\
\hline Otros peces marinos & & & $\mathrm{x}$ \\
\hline
\end{tabular}

Clave: *animales que no eran criados, pero se mantenían cautivos.

Cuadro 3. Animales cuyos restos se han descubierto en Teotihuacan y que eran empleados como alimento. En varios casos, sobre todo conejos y liebres, es posible que se les manejara al interior de algunas casas, teniéndoles cautivos hasta que llegara el momento de utilizarlos. 
Pero lo interesante aún no termina, pues hay especies que no existen de forma natural en el Valle de Teotihuacan, es más, ni siquiera en el centro de México, es decir, que se trata de alimentos que provenían de grandes distancias, por ejemplo del Valle de Morelos o de la costa del Golfo (Cuadro 3). Esto es importante porque nos muestra hasta donde disponía la ciudad de una organización adecuada para poder aprovisionarse este tipo de alimentos. Quizá lo más destacable son las diferentes especies marinas, como las mojarras, los huachinangos y los robalos, que han aparecido en algunos lugares de la ciudad, no obstante que se trata de peces que habitan sólo las costas.

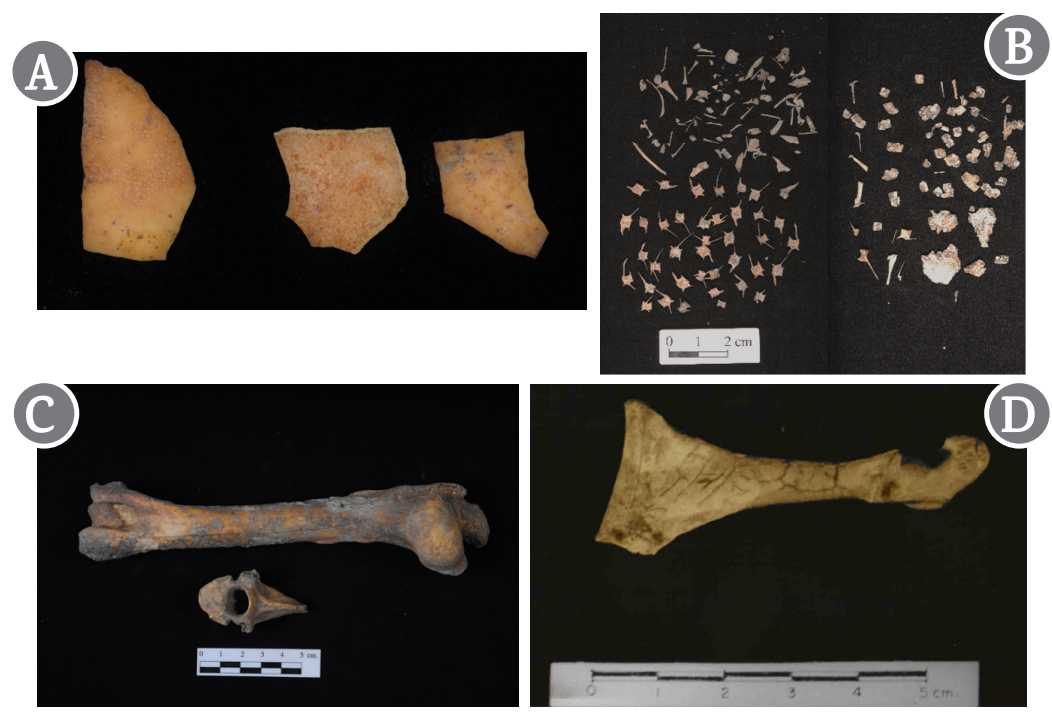

Figura 11. Ejemplos de restos faunísticos encontrados en Teotihuacan y relacionados con el alimento. (A), cáscaras de huevo de guajolote (inicio de fase Tlamimilolpa); (B), restos de sardinas (inicio de fase Tlamimilolpa); (C), húmero y vértebra dorsal de venado cola blanca (final de fase Xolalpan); (D), coracoides de ganso (fase Xolalpan). Fotografía B del Barrio de los Comerciantes, fotografías A, C y D del centro de barrio de Teopancazco. (Fotografías de Rafael Reyes). 


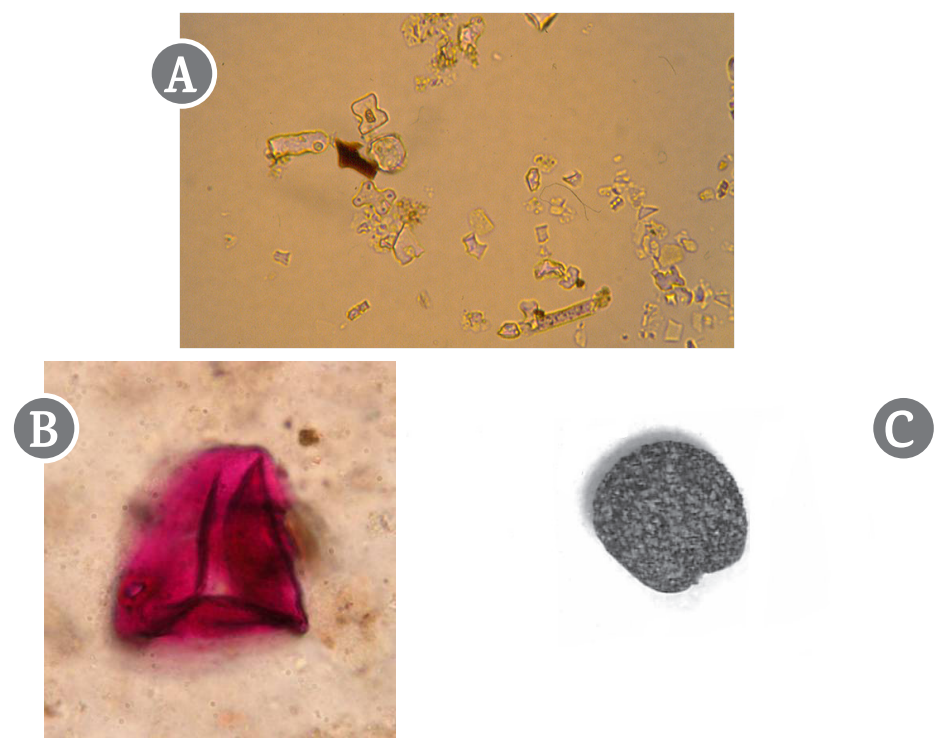

Figura 12. Ejemplos de restos vegetales asociados con la alimentación descubiertos en el centro de barrio de Teopancazco, fase Xolalpan. (A), fitolitos de maíz; (B), grano de polen de maíz; (C), semilla de jitomate silvestre, jaltomata. (Fotografía A de Judith Zurita, fotografía B de Emilio Ibarra, fotografía C de Diana Martínez y Cristina Adriano).

Diversos organismos solo se han descubierto de forma ocasional, por ejemplo ranas o charales, pero se considera que esto es producto de su pequeña talla, lo que limita enormemente su preservación. Partiendo de este aspecto debemos hacer conciencia de que otras tantas especies podrían haberse aprovechado pero no hay registro de ellos porque no pudieron conservarse o sus restos o las evidencias de su empleo, por ejemplo insectos, miel, huevos de diversas aves, tubérculos como el camote y sin duda todo un mundo de hongos colectados año tras año en los bosques.

Un aspecto relevante es donde aparecen generalmente estas evidencias. Hemos comentado casos como las ollas, los metates o el interior mismo de las unidades habitacionales, sin embargo la principal fuente de información es ila basura! 
Sí, sin duda los contextos asociados a materiales desechados son una muy importante fuente de información, tal y como lo son en la actualidad. Para el caso teotihuacano un posible basurero podemos reconocerlo por poseer piso de tierra, encontrarse en el exterior de las unidades habitacionales y por el predominio de objetos diversos que muestran una clara condición de abandono.

La forma en que esta basura era conducida fuera de la ciudad es algo que desconocemos, pero así como se disponía de un sistema de drenaje y calles estucadas, es seguro que habría un sistema de recolección de basura. Lo que sí sabemos es que no se le dejaba en un lugar abierto y abandonado, fuera de la ciudad, sino que podía utilizarse en las obras arquitectónicas, para rellenar espacios, por ejemplo en la construcción de una pirámide o para elevar el nivel de los pisos de cuartos y patios que eran remodelados y que siempre se construían encima del nivel anterior. De este modo, al realizar una excavación en un lugar de la ciudad, al encontrar un contexto del tipo de relleno arquitectónico, es probable que estemos viendo una acumulación de antigua basura.

Otro contexto diametralmente opuesto en su relevancia cultural que proporciona información sobre lo alimentario son las ofrendas y los entierros, algo lógico, si consideramos, por un lado, el cuidado que siempre se tiene al descubrirse un contexto ordenado y hecho con fines religiosos; por otro lado, muchas veces se realizaban bajo altares o pisos de las casas, lo cual promovía su preservación hasta su descubrimiento. Más adelante retomaremos este tema con más cuidado.

La tercera opción para dar cuenta de alimentos son los restos de banquetes multitudinarios donde es posible reconocer restos faunísticos, botánicos, arqueológicos y químicos en una misma zona.

$\mathrm{Y}$ es hasta este momento, que tenemos a los propios espacios habitacionales como fuentes de información, pues aunque proporcionen datos directos del uso de plantas y animales para lo 
alimentario, en realidad es muy poco probable que en un cuarto donde se prepara alimento se quede un hueso sobre el piso, por largo tiempo, sin que nadie se percate de él. En realidad estos valiosos hallazgos casi siempre corresponden a momentos previos al abandono súbito o al momento en que el piso es cubierto por otro o por una capa de tierra de forma intencional.

Un último aspecto sobre la despensa del teotihuacano es, ¿las especies presentadas en los Cuadros 2 y 3 fueron fuentes de alimento aprovechadas de manera homogénea y uniforme por todos?

Para responder a esta pregunta necesitamos ver lo que nos dicen los estudios de isótopos, tema que se describió páginas atrás (Figura 5). En los últimos 15 años se han hecho investigaciones con individuos provenientes de entierros de diversos sitios dentro de la ciudad y lo que se ha visto es que, en general, el maíz fue el alimento principal. Alrededor del $80 \%$ de la alimentación de los teotihuacanos estaba constituida por organismos C4 y CAM, es decir maíz, amaranto, verdolaga, animales que se alimentaban de la milpa (total o parcialmente), como guajolotes, conejos, liebres, venados, así como nopales, tunas, aguamiel y pulque, completada por plantas C3 y animales que se alimentaban de este tipo de vegetales, es decir frijol, diversas frutas y especies silvestres de diversos ámbitos terrestres y lacustres.

Caso importante, aunque no muy frecuente, fue el de personas que al estudiarse se vio que habían tenido una dieta rica en productos marinos. Estos individuos, que gracias a la datación por radiocarbono sabemos vivieron principalmente en la fase Tlamimilolpa, se descubrieron en el centro de barrio de Teopancazco (Figura 4), lugar donde se han recuperado numerosas evidencias de que tenían una importante relación con los pueblos de la costa del Golfo de México y lugar donde se han identificado las especies de peces marinos que se muestran en el Cuadro 3. 
De este modo, la imagen general es que los teotihuacanos tenían acceso a numerosas especies de organismos, aunque una docena de ellas constituían la base de su alimentación, principalmente los organismos provenientes de la milpa (desde el maíz hasta hongos e insectos) y los que eran aptos para crecer de forma silvestre o cultivada en el valle, principalmente magueyes, nopales y sus productos como tunas, aguamiel, pulque, garambullos (flor del maguey) y gusanos de maguey, por mencionar solo los más conocidos. Este cuadro de alimentos se completaba con organismos diversos provenientes de los bosques, lagunas y cultivos, desde charales hasta frijoles y desde miel hasta hongos.

\section{Lista de las obras empleadas en la elaboración del capitulo}

$15,18,19,21,32,33,35,36,39,40,43,44$. 


\section{La comida en las horas de trabajo}

Teotihuacan fue una ciudad con un relevante esquema productivo que requirió de una eficiente organización la cual abarcaba a toda la población.

Cuando se habla de trabajadores que deben comer en sus espacios laborales pensamos en las ciudades actuales, nadie pensaría que algo así lo podríamos tener en una ciudad prehispánica, no obstante hay algunos detalles que nos obligan a pensar en la posibilidad de que esto se diera en Teotihuacan.

El primer dato, y sin duda el más relevante, se relaciona con el centro de barrio de Teopancazco (Figura 13), lugar estudiado en los últimos 15 años y donde se descubrió que parte de las actividades, o quizá la principal, en los periodos Xolalpan y Metepec, era la confección de vestimentas de uso ritual, para sacerdotes, en eventos de tipo ceremonial.

A diferencia de lo que vimos en el capítulo anterior respecto de lo que era una unidad habitacional teotihuacana y sus actividades, el centro de barrio era un espacio más bien de tipo administrativo, que controlaba las actividades dentro de un determinado sector de la ciudad. En este centro de barrio trabajaban artesanos elaborando las vestimentas indicadas, sus ayudantes, además de los propios líderes del sitio.

Dentro de las excavaciones fue descubierto, en la porción norte (Figura 13) un conjunto de pequeños cuartos de unos seis o siete metros cuadrados, alineados, y en su interior aparecieron numerosas piezas de cerámica y lítica, entre las que destacaron parte de un metate y grandes ollas, así como residuos químicos $\mathrm{y}$ algunos restos vegetales y animales y fragmentos de varios metates con fitolitos de especies comestibles como maíz, calabaza y frijol. La conclusión fue que estos cuartos se relacionaban con 


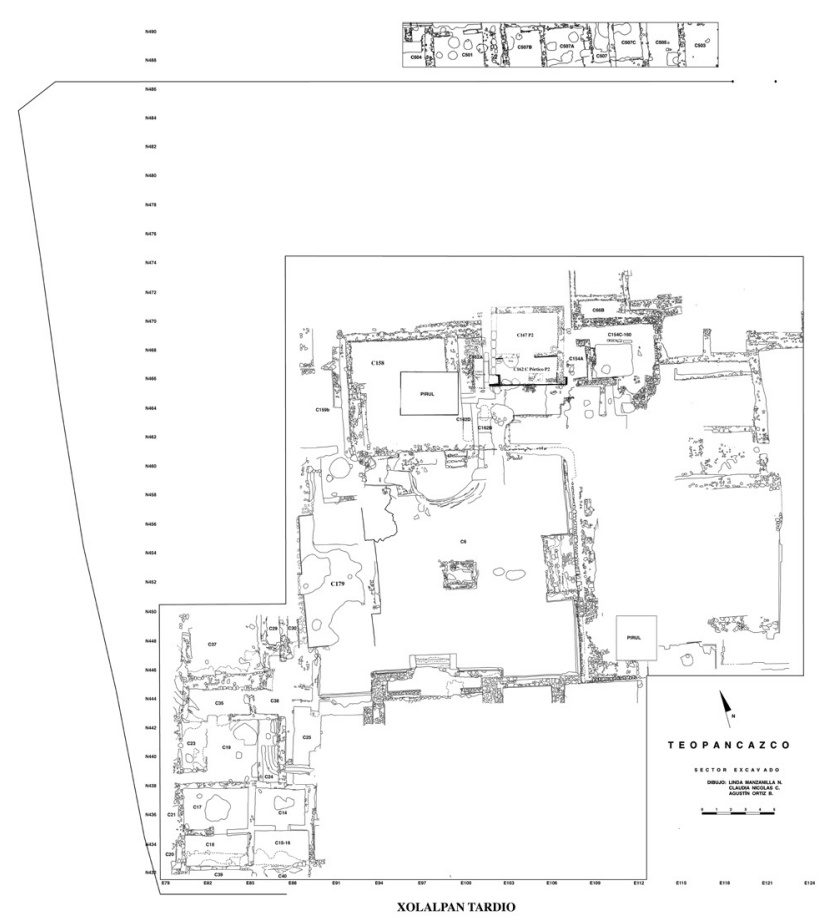

Figura 13. Plano del centro de barrio de Teopancazco al final de la fase Xolalpan. Se considera que los cuartos de la parte norte (extremo superior), eran cocinas o lugares donde se tenía comida que se distribuía a los trabajadores y artesanos que laboraban en el barrio. (Elaboró L. Manzanilla, C. Nicolás y A. Ortíz).

aspectos de alimentación, como su almacenamiento y quizá elaboración, pero su pequeño tamaño y su acomodo en fila les hace parecer más como un espacio especializado en guardar y repartir alimento, muy probablemente para la gente que trabajaba aquí.

No obstante que se trata de una idea muy original, sin precedente, se complementa muy bien con lo que vimos en el capítulo anterior sobre las unidades habitacionales teotihuacanas, con 
sus limitaciones respecto de las áreas donde se podría elaborar el alimento. De esta forma, si pensamos que muchas de las familias vivían en un esquema en el que parte de ellos (adolescentes y adultos varones y quizá algunas de las mujeres) comían en sus espacios de trabajo y en la casa lo hacían más bien los niños y sus madres, esto haría más fácil entender cómo es que un anafre podía ser suficiente para cubrir las necesidades de una o varias familias que ocupaban la unidad habitacional.

Esto, sin embargo, no significa que todos los que trabajaban en Teotihuacan hicieran lo mismo. Para el sitio de Oztoyahualco (Figura 10), se estableció que había sido ocupado por tres familias, en parte porque se descubrieron evidencias de otros espacios, además del llamado C3-4, donde podrían haberse preparado alimentos, por ejemplo la esquina de un pasillo. Esta situación quizás fue el resultado de diferentes lugares para elaborar la comida en función de la familia involucrada o que tal vez se trataba de condiciones ocasionales o limitadas a ciertas personas que sí comían en sus casas.

Otro caso más a considerar se refiere al tiempo en que se construyó el centro ceremonial, en especial la llamada "Calzada de los Muertos”. Pertenecientes a la fase Miccaotli se han descubierto espacios con gran cantidad de metates que indican continuo trabajo en la elaboración de masa de maíz y de alimento en general y la propuesta es que en ese periodo se le daba de comer a los trabajadores para optimizar el tiempo y, sin duda, como parte de su retribución. Sin duda en esos momentos Teotihuacan era mucho más pequeña de lo que aparece en la Figura 4, empero se consideró importante impulsar este esquema de organización y es posible que desde entonces quedara como parte del sistema productivo y de derecho de los trabajadores.

Esta misma organización se aplicaría a otros casos, en los que parte de la familia salía a trabajar al campo, ya fuera en labores agrícolas, en criaderos, cazando o pescando, sin olvidar que 
Teotihuacan era una ciudad en constante movimiento y que las obras arquitectónicas, la remodelación de los edificios, la producción y manejo de la cal, los servicios, el comercio y otras tantas actividades exigían a la gente varias horas de labores con sus espacios de comida que, quizá con mucha frecuencia, se realizaban fuera de su casa.

Lista de las obras empleadas en la elaboración del capitulo

3, 13, 15, 18, 19, 21, 24, 28. 


\section{Comidas y ofrendas}

Dentro de la civilización mesoamericana el comer, alimentarse, no era sólo una actividad de subsistencia, pues las evidencias arqueológicas muestran que el aspecto religioso estaba presente. En el capítulo anterior se comentó que los contextos rituales eran una buena fuente de información sobre lo alimentario, pero además de lo arqueológico hay aspectos culturales de gran relevancia.

Dentro de la civilización mesoamericana se creía que todos los seres vivos formaban parte de un universo organizado por los dioses y cada animal o planta jugaba un papel dentro de él. Por otro lado, se pensaba que, al menos respecto de los animales, cada individuo poseía una esencia anímica y que cuando se le comía, ésta pasaba de un organismo al otro, por lo que, para el caso de los humanos, el consumo de la carne estaba regulado por normas religiosas, a fin de asegurar que todo se hiciera dentro de un marco de equilibrio simbólico a nivel animales, personas, fechas y razón del evento. De acuerdo con ello, cada resto animal y vegetal que estudiamos, aunque esté asociado con alguna actividad práctica, como lo es la alimentación, sin duda también posee información relacionada con aspectos simbólicos que tuvieron algún valor en el momento.

Para ilustrar esto empleemos dos casos (Figura 14). Uno de ellos se refiere a los conejos en el sitio de Oztoyahualco. Como se mencionó, en esta unidad habitacional del final de la fase Xolalpan (Cuadro 1), aparecieron numerosos restos de conejos y liebres, casi la mitad del total de la colección, la mayoría en un traspatio como restos alimentarios (Figura 14A), pero también aparecieron huesos cocidos junto a entierros o en fosas dentro de algunos cuartos. Posteriormente se descubrió una escultura de conejo (Figura 14B) en otra parte de la unidad y con ello fue claro que aunque estos animales se utilizaban como alimento, para la gente del sitio tenían asimismo un significado especial, quizá eran símbolos del clan. Su manejo era 
lo bastante intenso para proponer que se les tenía cautivos dentro de la unidad, propuesta basada en su abundancia, en el hallazgo de una posible conejera y en los valores de isótopos obtenidos en un estudio realizado posteriormente, el cual indicó que su dieta estaba basada mayormente en el maíz. Lo único que no hizo la gente, quizá porque no era su objetivo, fue domesticarlos, es decir, buscar su reproducción en cautiverio.
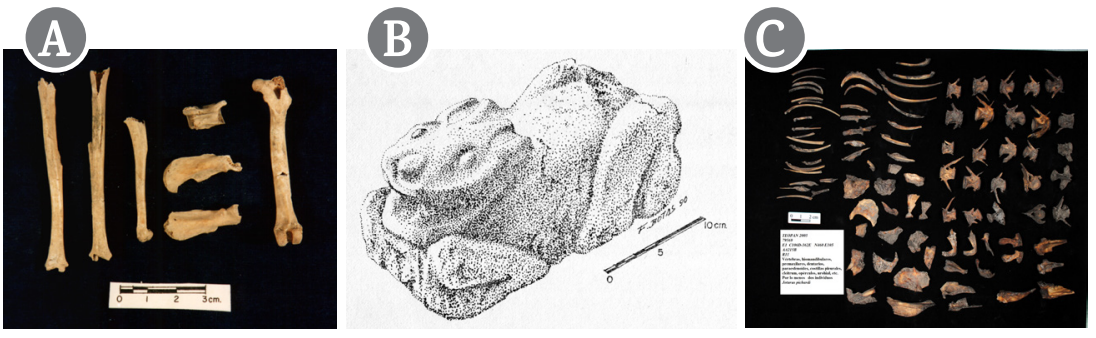

Figura 14. Ejemplos de fauna descubierta en Teotihuacan, cuyas características le asocian con lo alimentario y lo religioso simultáneamente. (A), huesos de conejo castellano (Syfvilagus floridanus); (B), escultura de conejo (género Syfvilagus); (C), Huesos de varios individuos de pez bobo (foturus pichardî), empleados como parte del alimento en un banquete ritual en el centro de barrio de Teopancazco. (Para más información ver texto). (Fotografías A y C de Rafael Reyes, dibujo de Fernando Botas).

El otro ejemplo proviene del centro de barrio de Teopancazco. Perteneciente al inicio de la fase Tlamimilolpa (Cuadro 1) se descubrió una fosa donde aparecieron gran cantidad de cerámica, huesos, algunos restos de plantas y se concluyó que era un basurero relacionado con un banquete ritual. Una de las especies más abundantes fue un pez, llamado pez bobo (Joturus pichardi) (Figura $14 C$ ), que vive en los ríos de la costa del Golfo de México y baja a desovar a las desembocaduras en noviembre, momento en que es capturado. Como en este mes también se inicia la cosecha del maíz, cuyos restos aparecieron en dicho basurero, se concluyó que el banquete se habría hecho en algún día de ese mes para celebrar el final del ciclo agrícola, agradecerles a los dioses su apoyo y para dicho evento se utilizaron 
organismos que estaban asociados con ese momento del año, parte de los cuales fue consumido por la gente y parte depositado en la fosa, porque posiblemente era la porción de la comida "que le correspondía a los dioses".

Los ejemplos antes mencionados son muy claros para ilustrar la idea presentada, pero no son los únicos, pues lo normal es que cada especie animal y vegetal descubierta en Teotihuacan se haya descubierto en espacios de uso doméstico, por ejemplo basureros, patios, talleres, sobre pisos, en drenajes, pero igualmente los tenemos en entierros y en fosas bajo los pisos de cuartos o altares.

Debido a la multitud de contextos donde podemos encontrar alguna relación con lo alimentario, cuando hablamos de restos involucrados con esta actividad partimos de especies, y sus partes, que tradicionalmente asociamos con ese fin, por ejemplo olotes de mazorcas de maíz o huesos de piernas de venado, y si estos elementos tienen algo más, como que estén carbonizados, entonces la propuesta está firmemente apoyada, sin importar donde se les haya descubierto. Muchas veces, sobre todo en el caso de plantas, los materiales que se pueden identificar son los más íntegros, es decir, sin huella de cocimiento o manejo, pero si el hallazgo involucra partes comestibles, generalmente es suficiente para proponer que su empleo se relacionó con el alimento (Figura 15).

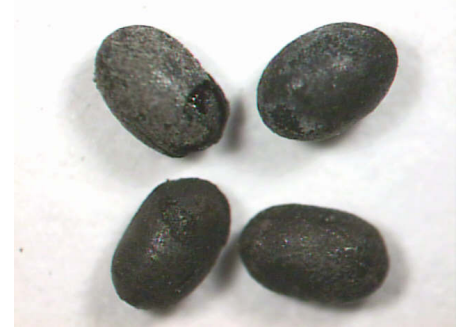

Figura 15. Semillas de chía descubiertas en el centro de barrio de Teopancazco, fase Xolalpan. La chía tenía usos alimentarios, pero también un fuerte simbolismo religioso por su asociación con el agua. (Fotografía de Diana Martínez y Cristina Adriano). 
Cuando nos encontramos en el lado opuesto, en contextos donde lo religioso se manifiesta ¿qué elementos encontramos que los liguen con el alimento?

Sin duda el caso más frecuente son fosas que se hicieron bajo los pisos y que se reconocen por una línea circular y las diferencias en coloración que pueden indicar un evento en el cual se rompió parte del piso de estuco, se hizo un agujero, dentro de éste se colocó algo y posteriormente se rellenó, emparejó y se reparó (hasta donde fue posible) el piso. Desafortunadamente una gran parte de las fosas que se descubren fueron saqueadas en algún momento, por lo que solo se recuperan unos pocos materiales, pero aun así son frecuentes los casos en los que tenemos fragmentos de ollas, vasos, platos, y muchas veces están a un lado huesos cocidos o aparece el polen y otros restos de plantas alimentarias. Si las fosas están al interior de un cuarto, sobre todo cerca de una pared, son ofrendas que se hicieron a la construcción, para pedirles a los dioses un buen futuro. Ciertamente lo alimentario puede estar presente, aunque una ofrenda con este fin también puede involucrar a bebés humanos, crías de perros, herramientas, tejidos, conchas marinas, lítica y cerámica, por decir lo menos.

Otro caso son las fosas que pueden preservar materiales de eventos, como el banquete descrito líneas arriba, cuyo fin era ofrecer parte de la comida a los dioses. Además tenemos las que aparecen junto a los altares y que se consideran el resultado de acontecimientos religiosos que concluyeron con la colocación de una ofrenda a los dioses, parte de la cual puede incluir alimento o materiales relacionados con lo alimentario, pues siempre les era necesario agradecer los favores recibidos, comida incluida.

Un caso interesante se descubrió en el sitio de Teopancazco dentro de la fase Tlamimilolpa. Junto a un pequeño altar muy destruido, en cuyo interior apareció gran cantidad de material cerámico, huesos humanos, de animales y asociados a unos vasos polícromos, semillas de fabaceas (frijol y especies relacionadas), huauhtzontle, jaltomate 
(tomatillo), tuna, maíz y gran cantidad de chía, todas ellas, plantas de uso alimentario. Se piensa que el evento tuvo por fin celebrar la terminación de una época o periodo.

Pero, sin duda lo más espectacular son los entierros, en los cuales es frecuente la presencia de materiales dejados al difunto y parte de esto, son alimentos, es decir, comida que el muerto empleará a donde sea que llegue. En ocasiones la ofrenda alimentaria aparece colocada sobre platos o en pequeñas ollas. Los animales más frecuentes son conejos, liebres, perros, guajolotes, venados, patos, en Teopancazco peces marinos. Respecto de plantas tenemos, por ejemplo, la chía.

Otro tipo de hallazgo es el de manchas a modo de salpicaduras o líquido que cae, que aparecen sobre la superficie de los patios, incluso manifestando "trayectorias o caminos" que se recorrían. El estudio de estos rastros ha determinado que se trata de espacios con enriquecimiento químico y se interpreta que fue sangre de animales que se iba derramando mientras los sacerdotes caminaban y realizaban determinado rito, o también sangre de humanos que se ofrecía a los dioses. Por el tipo de hallazgos que se han descubierto en las ofrendas asociadas a los altares, es seguro que muchos de los organismos sacrificados fueron después cocinados y comidos, dejando parte en una fosa.

Por último, consideremos tres casos de organismos a los que generalmente no asociamos con la alimentación y los ritos, pero que las evidencias así lo demuestran para Teotihuacan.

El primero se relaciona con la chía (Salvia híspanica), la cual se utiliza (y seguramente se utilizaba) para preparar bebidas frescas, como pinole, junto con el maíz para hacer atole y para ayudar en las labores de parto. A nivel simbólico, su estrecha relación con los ambientes muy húmedos le asocia con el agua (Figura 16). Líneas arriba se comentó su presencia en una ofrenda localizada en el centro de barrio de Teopancazco y otro caso es su hallazgo como parte de un entierro que apareció dentro de la Pirámide del Sol en sus épocas más tempranas. 
Quizá el entierro tenía una dedicación especial al elemento agua, siendo la chía parte de los elementos que se pusieron para cubrir el rito. En la Pirámide de la Luna, apareció chía bajo un plato dentro de una ofrenda dedicada al edificio (inicio de fase Tlamimilolpa), ofrenda que incluyó el sacrificio de numerosos humanos, lobos, águilas reales, pumas, coyote, híbridos de lobo y perro y una serpiente.

El segundo caso especial corresponde al perro. Sus restos están en

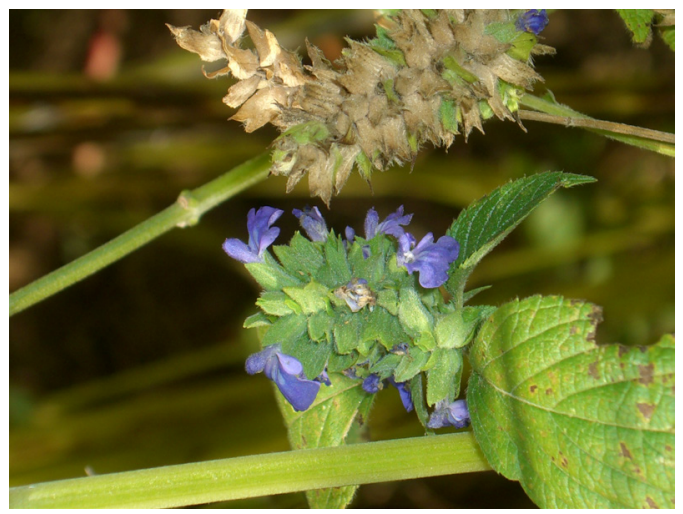

Figura 16. Flor de la planta de la chía (Fotografía proporcionada por Robert Bye, 2010).

todo contexto imaginable, desde basureros hasta el interior de la Pirámide de la Luna y el Templo de Quetzalcoatl, y gran cantidad de ellos muestran evidencia de haber sido consumidos, sin embargo esta acción parece estar orientada en función del tipo de perro y la actividad realizada.

Los perros comunes, es decir, perros medianos, amarillos, blancos o negros, con el cuerpo cubierto de pelo son los que vemos en las unidades habitacionales, en basureros, espacios domésticos y como ofrenda alimentaria (Figuras 17A,B). En contextos funerarios o rituales de más alto nivel, además de los perros comunes, también tenemos a unos perros de patas cortas llamados tlalchichis (Figura 17C), a híbridos de coyote y perro o de lobo y perro (Figura 17D) y, si se 
trataba de actos ceremoniales más relevantes aún, lo que aparecen son estos últimos y sus contrapartes silvestres: el coyote y el lobo.

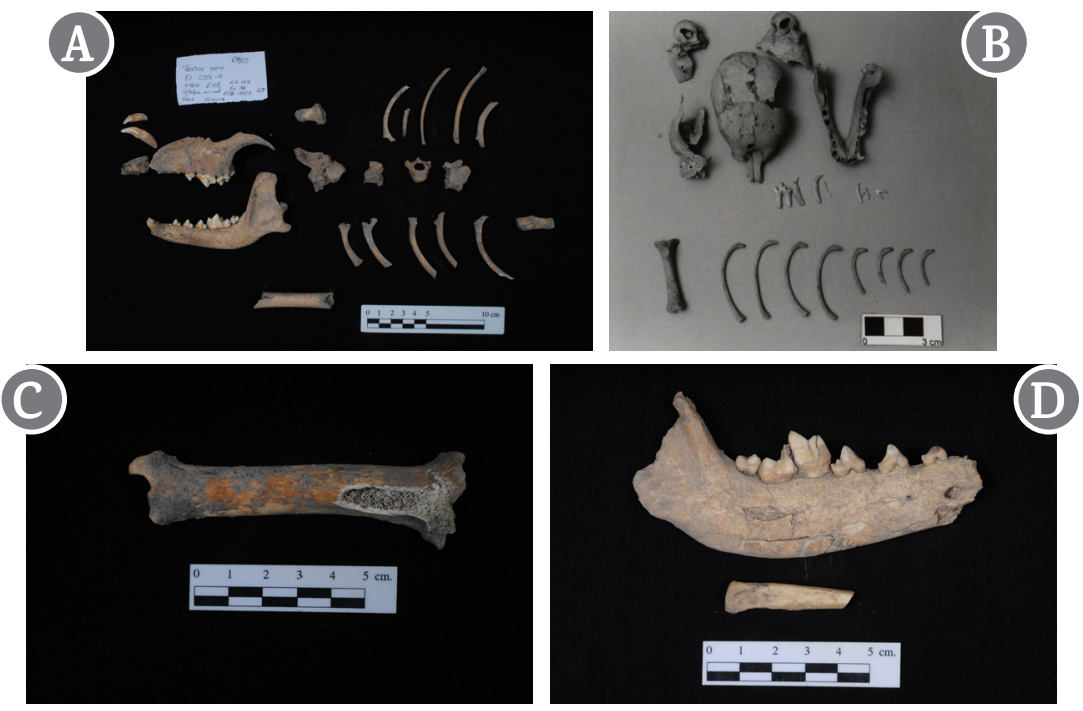

Figura 17. Cuatro ejemplos de perros cuyos restos indican que fueron cocidos, consumidos y finalmente depositados en espacios rituales. (A) hembra adulta tipo común, colocada dentro de un entierro de inicios de fase Tlamimilolpa en Teopancazco; (B) cría de perro común de tres meses de edad, colocada como parte de una ofrenda bajo el piso de un cuarto en Tetitla, fase Xolalpan; (C), tibia de perro de patas cortas de final de fase Xolalpan, descubierta bajo el piso de un cuarto en un relleno de carácter ritual, en Teopancazco; (D), mandíbula de híbrido de lobo y perro de en otro relleno de carácter ritual, en Teopancazco, fase Metepec. (Fotografías de Rafael Reyes).

Integrando esta información, podemos concluir que dependiendo del nivel social y la naturaleza de los actos rituales se definía el tipo de cánido a emplear y por tanto mucho de su uso como alimento estaba ligado a circunstancias religiosas bien definidas. Dato complementario es que en Teotihuacan jamás existieron los perros pelones, mismos que en esa época ya existían, pero circunscritos al occidente de México, su lugar de origen. Los más tempranos restos de 
xoloitzcuintles identificados en el valle de Teotihuacan pertenecen al siglo VIII de nuestra Era, un siglo después de que esta urbe había dejado de existir.

El tercer caso corresponde al propio $\mathcal{H}$ fomo sapiens. Contrario a lo que se podría suponer, los huesos humanos son muy abundantes en los basureros y rellenos constructivos y la gran mayoría manifiestan cocimiento y/o marcas de mordidas. Esta innegable e indiscutible realidad fue causa de que antaño se pensara que los habitantes de la ciudad vivían en un estado de hambruna permanente al grado de que se comían unos a otros. Ahora que podemos asegurar que existían suficientes recursos alimentarios y buena organización, podemos asegurar que todo está relacionado con prácticas religiosas.

Un aspecto relevante que debemos considerar es que una cosa son los hombres descubiertos en entierros y otro los restos cocidos provenientes de ofrendas o de basureros. Es muy probable que los segundos fueran principalmente cautivos de guerra que, como en el caso de animales y plantas, participaban en ceremonias donde se les sacrificaba y como parte del protocolo su carne era repartida y consumida por los asistentes a fin de unirse espiritualmente dentro de la ceremonia. Sabemos que muchas veces los huesos eran recuperados y empleados para elaborar instrumentos, desde cuencos hasta agujas de costura y el ADN estudiado muestra que los huesos pertenecieron a individuos de condición foránea. Algunos piensan que una vez concluido el acto donde se les sacrificó, sus restos quedaban en manos de una sola persona o bien estarían disponibles para quien quisiera, una forma más de vincularse espiritualmente con el individuo, el acto ritual y los dioses.

\section{Lista de las obras empleadas en la elaboración del capitulo}

$12,14,15,18,19,20,21,43,44$. 


\section{¿Cómo llegaba la comída a las casas?}

Existen estudios de densidad de población que hablan de la forma como fue creciendo Teotihuacan al paso de los años. Para la fase Tzacualli (Cuadro 1) en el primer siglo de nuestra Era, su población era de unos 60,000 habitantes y para la fase Xolalpan, 500 años después, se cree que era de unos 150,000. Este crecimiento, en un ritmo promedio de 20,000 personas por siglo, en realidad no fue tan constante, pues hubo factores que en su momento jugaron un papel esencial, sobre todo la enorme relevancia que alcanzó a partir de la fase Tlamimilolpa, ya que desde ese entonces empezó a llegar gran cantidad de gente buscando dónde establecerse o para aprovechar sus recursos, conexiones, redes comerciales y otros aspectos que sólo podían encontrarse en una ciudad cosmopolita. Este crecimiento llegó a su máximo en la segunda mitad de la fase Xolalpan, cuando alrededor de un tercio de la población era de condición flotante, es decir, pasaba gran parte de su tiempo en la ciudad, pero en realidad iban y venían por distintos puntos de Mesoamérica.

Conforme este esquema se fue estableciendo y la ciudad poco a poco se transformó en una urbe donde la gente pasaba su vida laboral en un taller, en las eternas actividades de remodelación y trabajo arquitectónico, en el mantenimiento, los servicios o en actividades relacionadas con la crianza o la agricultura en la periferia, fue disminuyendo la importancia de los espacios en las unidades habitacionales, perdiendo la infraestructura necesaria para que ahí mismo produjeran y prepararan su alimento. Justo de ahí se deriva la pregunta clave de este capítulo: ¿De qué medios disponían para hacerse de los alimentos que requerían?

Hemos ya reflexionado acerca de que muchos teotihuacanos comían en sus lugares de trabajo y ciertamente en el presente la mayoría de los investigadores que han trabajado Teotihuacan coinciden en que una ciudad de este tamaño debía tener un esquema de abasto 
que permitiera a sus pobladores obtener sus alimentos dentro de la misma ciudad, sin tener que cultivarlos, criar animales o salir a pescar, cazar o colectar. Ciertamente se trata de una idea muy lógica pero, ¿qué evidencias tenemos al respecto?

La respuesta se iniciará con la gráfica que se muestra en la Figura 18 y que se relaciona con estudios de elementos traza hechos con personas de dos sitios teotihuacanos, con otras que vivieron en el valle, pero de tiempos posteriores y de diversos mamíferos que sirvieron de comparación para entender lo que significaba que un humano tuviera tales o cuales valores de los dos elementos.

Recordemos que con los elementos traza, en especial con el estroncio (Sr) y el zinc (Zn), podemos reconocer qué tanta carne o vegetales consumió una persona durante su existencia a través de los niveles de acumulación de estos elementos en los huesos (Figura 5C). Este

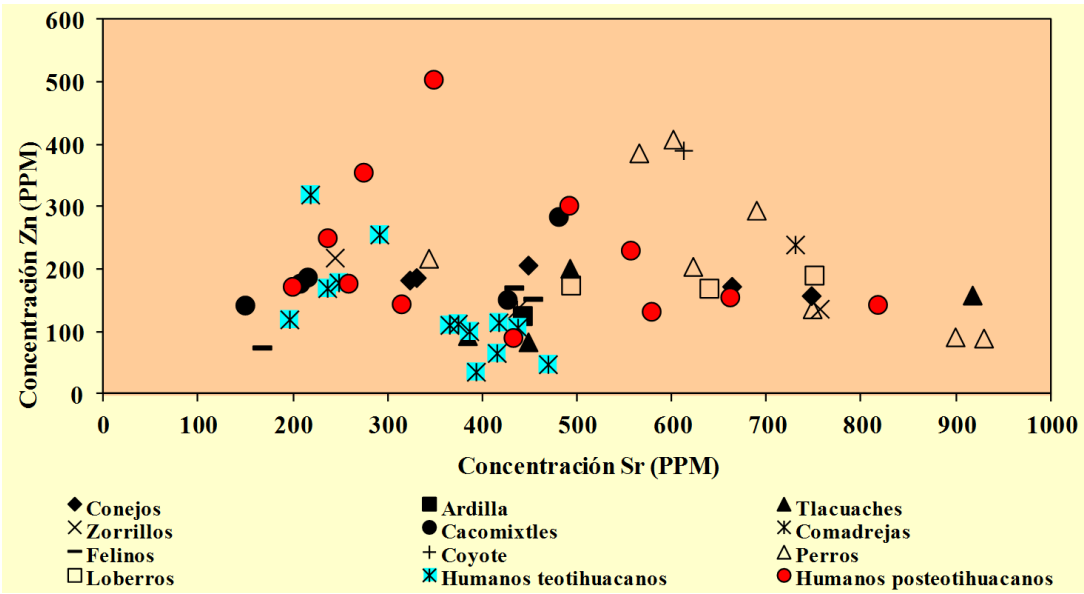

Figura 18. Concentración de Estroncio (Sr) y Zinc (Zn) en individuos de tiempos teotihuacanos (cuadros azules), posteotihuacanos (círculos rojos), perros (triángulos sin color) y mamíferos silvestres. El acomodo de cada caso indica, con ciertas reservas, la importancia que tuvieron la carne y los vegetales en su dieta y los conjuntos de individuos en un espacio reducido, tendencias alimentarias similares. (Para más información ver texto) (Elaboró Raúl Valadez). 
aspecto, el del consumo de carne, será de gran relevancia más adelante, pero en este momento dirigiremos nuestra atención al aspecto de diversidad alimentaria.

Concentremos nuestra atención en la forma como ciertas especies se distribuyen en la gráfica. Si observamos a los triángulos negros que representan a los tlacuaches, se encuentran en la parte baja de la gráfica, a todo lo largo, lo que significa poca carne en su dieta y mucha diversidad en lo que a vegetales se refiere. Respecto de los perros (triángulos vacíos), aparecen en todas partes, mostrando así lo que todos sabemos: que comen de todo. Ahora veamos cómo se comportan los humanos de época posteotihuacana y lo que salta a la vista es que su distribución es similar a la de los perros, es decir, que hay desde los que comieron mucha carne, quizá porque eran buenos cazadores, hasta los que vivían de la agricultura. Cuando hablamos de tiempos posteotihuacanos nos referimos a gente que vivió en aldeas o en pequeños pueblos, nunca en una gran urbe, por lo que es seguro que cada quien veía por sí mismo y su familia, respecto de que comer y donde conseguirlo.

¿Y qué hay de los teotihuacanos urbanos? Como ven, aparecen abajo a la izquierda, divididos en dos grupos pero formando verdaderos paquetes, con tendencias a un alto consumo de vegetales (recordemos que anteriormente se enfatizó la enorme importancia del maíz en su dieta), pero lo relevante es al estar reunidos, significa alimentación parecida.

Si los teotihuacanos hubieran comido lo que ellos mismos cazaran o cultivaran, se mostrarían igual a la gente de tiempos posteriores, pero al no ser así lo que se demuestra es que en general su dieta estaba constituida por un conjunto limitado y constante de alimentos, los cuales muy probablemente llegaban a la ciudad a través de un sistema de abasto, tal y como se indicó arriba, pero que gracias a este estudio pasamos de un "quizás" a un "sin duda", es decir, podemos asegurar que los teotihuacanos obtenían sus alimentos sin salir de la urbe gracias a esta red de abasto aunque, como cualquier otra (incluso 
en la actualidad), tenía sus limitaciones, quizá no en kilogramos de alimento, pero sí en número de productos, de ahí que aparezcan en la gráfica reunidos en grupo, pues sus alimentos básicos eran los mismos.

Habiendo cubierto este importante aspecto viene otro no menos relevante, ¿dónde estaban estos puntos de abasto?

En décadas pasadas se propuso que en el lado suroeste de la Calzada de los Muertos, frente a la Ciudadela, había existido un gran mercado, sin embargo los argumentos a su favor fueron pocos y dejó de considerarse. En el presente tenemos mejores explicaciones, por ejemplo que eran los centros de barrios los lugares a donde los productos llegaban y donde se organizaban la redistribución y los momentos de actividad mercantil.

En la actualidad es común que en la provincia mexicana existan "tianguis", es decir, mercados que funcionan cierto día de la semana, sobre todo el domingo, en el pueblo más grande, que muchas veces es también la cabecera municipal. Ese día llegan gran cantidad de comerciantes con cosas (alimentos entre ello) que traen de otras ciudades para vender o bien personas provenientes de pequeños pueblos que durante la semana elaboran artesanía, reúnen los productos de la cosecha, preparan alimentos típicos y todo lo llevan para vender en el tianguis, el cual, con mucha frecuencia, se organiza en la plaza principal.

En realidad esta forma de mercadeo, tan arraigado en la cultura mexicana, va muy acorde con lo que hemos visto para Teotihuacan (Figura 19), pues el punto clave es la organización que se requeriría para que, quienes dedicaban su esfuerzo en la producción de alimentos o su comercio y traslado desde regiones alejadas, tuvieran la oportunidad de comerciarlos o intercambiarlos en un día y lugar determinado, siempre siguiendo la norma existente. De esta forma, y justo como ocurre hoy, en ese día de tianguis veríamos a personas con sus productos, desde animales vivos hasta yerbas de usos diversos, y desde 

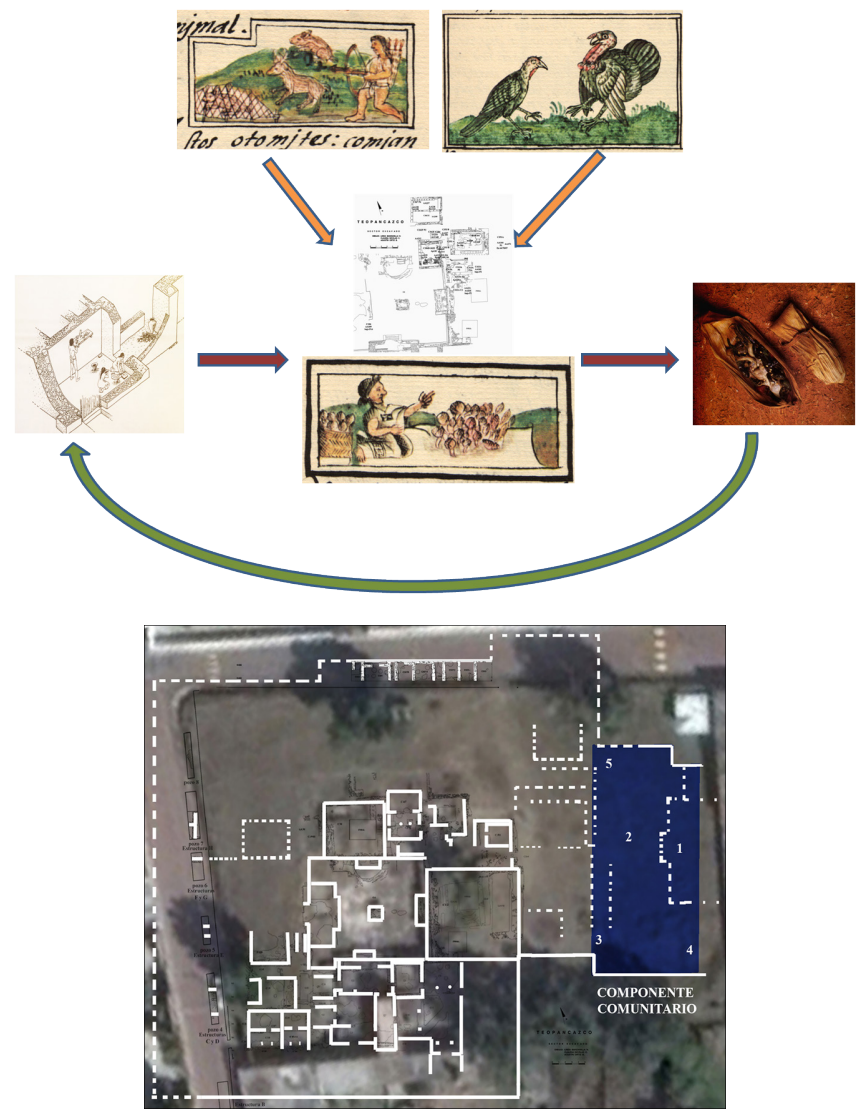

Figura 19. Muy probablemente los teotihuacanos en general (arriba a la izquierda) se abastecían de alimento y diversos productos a través de "tianguis" (mercado en el lenguaje tradicional mexicano) que se organizaban junto a los centros de barrio (centro). Los alimentos llegaban a través de personas que dedicaban su esfuerzo en la cacería, pesca, crianza, comercio (parte superior) o por intermediarios, permitiendo así que cada familia pudiera obtener los alimentos que requería (derecha), para consumirlos en los siguientes días. El plano de la parte inferior presenta el centro de barrio de Teopancazco y se considera que en el lado oriente existía un espacio abierto, sin piso de estuco, que serviría para la instalación periódica del tianguis. (Figuras sacadas de Sahagún 1979, plano de Teopancazco de Ortíz 2015, adaptación de Raúl Valadez). 
los que vivían dentro de la ciudad, pero eran agricultores o criadores en zonas de la periferia, hasta los que venían de regiones como la costa del Golfo de México. En la jornada de tianguis habría muchas personas que buscarían vender sus productos, pero igualmente obtener lo que les hiciera falta, quizá a través del intercambio: un guajolote por navajas de obsidiana o bien elotes por alimentos ya preparados, por ejemplo charales cocidos y envueltos en hojas de maíz. Es posible que todo el que quisiera pudiera participar, incluso los trabajadores de los talleres, que quizá en sus ratos de descanso podrían elaborar piezas que se cambiarían en el tianguis por alimentos.

En el párrafo anterior se habla de intercambio o venta. ¿Hay diferencia entre uno y otro?

Para el primero se considera que la acción de trueque es lo fundamental, producto te doy, producto me das, en tanto que la venta requiere de un instrumento con un valor intrínseco que constituye la base del proceso de adquisición, siendo la moneda el más empleado. Los teotihuacanos no conocieron los metales, así que no podía existir una moneda como la conocemos, pero se ha sugerido la posibilidad de que en estos centros de barrio se manejaran pequeñas piezas de cerámica con un valor determinado que quizá podría haber servido para estas ocasiones.

La relevancia de este tema es muy alta y muy importante para entender la organización de Teotihuacan y ciertamente falta aún mucho por estudiar, pero sin duda los avances son muy interesantes y demostrativos, dándonos la oportunidad de verla como una impresionante urbe.

\section{Lista de las obras empleadas en la elaboración del capitulo}

$17,19,24,28,29,31,35,39,40,46$. 


\section{¿De dónde venía el alímento que se comía?}

Se ha dicho que en Teotihuacan existieron varios centros de barrio (Figura 4), hasta veinte, dicen algunos arqueólogos de la zona, cada uno controlando cierto sector de la ciudad y especializado en determinadas actividades y productos. Hemos citado varias veces el caso de Teopancazco, cuya actividad principal fue la confección de vestimentas rituales, pero que igualmente tenían fuertes vínculos con los pueblos que van desde el valle de PueblaTlaxcala hasta la costa de Veracruz, por lo que los productos de esas zonas, en especial los costeros, sin duda serían un fuerte atractivo para parte de la población de la ciudad. Otro centro de barrio teotihuacano era la Ventilla, sitio localizado al suroeste de la Ciudadela y que se piensa que su relevancia comercial giraba alrededor de productos como el pulque.

Para los tiempos de Xolalpan es claro que la ciudad estaba fuertemente comprometida con actividades que poco tenían que ver con la producción de alimentos, incluso los resultados mostrados en el capítulo anterior llevaría a la conclusión de que eran pocas las personas que se alimentaban de algo que ellos mismos producían, pues hasta un caso como el de Oztoyahualco y los conejos, es único frente a las decenas de unidades habitacionales que se han estudiado, además de que se demostró que los intereses hacia estos animales iban mucho más allá de lo puramente alimentario.

Acerca de cuándo se inició el cambio, hemos visto diferentes evidencias de que en Tlamimilolpa aún existían unidades habitacionales más autosuficientes; por otro lado, durante los estudios de las ofrendas descubiertas en la Pirámide de la Luna, se vio que gran parte de los rellenos colocados durante las obras de ampliación (hace unos 1,600 años) a mediados de Tlamimilolpa (Cuadro 1) estaban constituidos por suelos agrícolas, lo que 
implicaba el abandono de la agricultura en las áreas circundantes a cambio ¿de qué?, quizá de más templos, más unidades habitacionales, es decir, se reducía un poco la autosuficiencia alimentaria por el desarrollo urbano y la monumentalidad de las pirámides, quizá con la idea de convertir a la ciudad en algo más atractivo, más impactante, de más fuerza social y política. Vale decir que ciertamente lo lograron.

¿Pero qué hay con el alimento? Sin duda el plan de trabajo teotihuacano fue ampliar su esfera de influencia directa a las regiones aledañas: el resto de la Cuenca de México, Valle de PueblaTlaxcala, Valle de Toluca, Valle de Morelos, y convertirlos en abastecedores de alimento para la ciudad. Sabemos que todo el sur de la Cuenca de México prácticamente se despobló por la actividad volcánica del Popocatepetl y el Xitle, de modo que les sería fácil organizar "colonias" dedicadas sólo a la producción de alimentos y, en otros casos, donde había una población mayor y estable, los productos que se necesitaban se obtendrían a cambio de ciertos beneficios, como el abasto continuo de productos teotihuacanos, o quizá hasta se llegó a emplear la fuerza militar y obligar a algunos pueblos a pagar un tributo.

Un interesante ejemplo respecto a lo que era este esquema de manejo de alimentos foráneos lo tenemos en Teopancazco. Ahí se han encontrado, como se indicó, huesos de peces marinos, la mayoría con evidencias de haber sido cocidos. Pero, ¿cómo podrían llegar peces obtenidos en la costa sin que entraran en descomposición? Los propios huesos ofrecen el dato de concentraciones de sal, lo que significa que sin duda estos peces eran preparados en los lugares donde se pescaban salándolos, ahumándolos y envolviéndolos en hojas de maíz, algo que aún podemos ver en los tianguis de diferentes ciudades de Puebla, Tlaxcala, Veracruz e Hidalgo. Incluso las vértebras de estos peces se observan como aplastadas, lo cual interpretamos como el resultado de que estos peces se acomodaran en pilas, se compactaran y así 
era más fácil su transporte (Figura 20). Como este caso, sin duda hubo otros muchos donde los alimentos se producían en una región, se preparaban y los transportaban para llevarlos a la gran urbe.

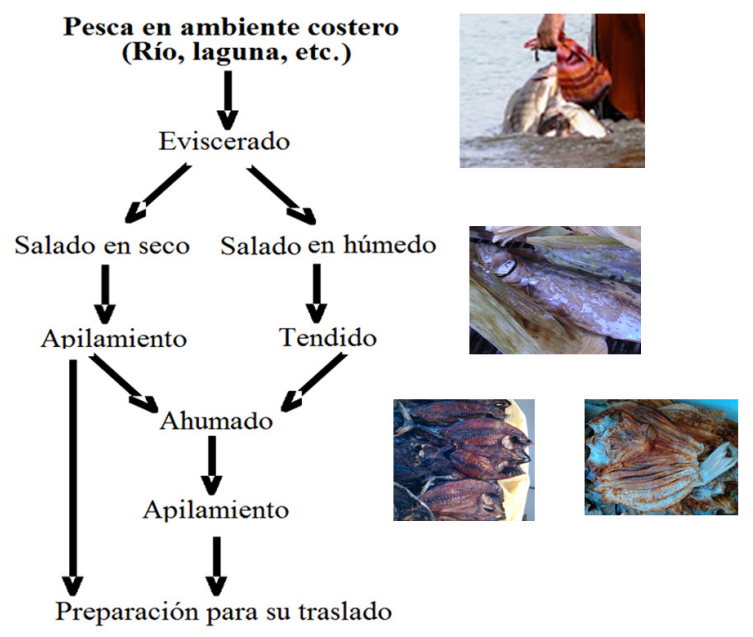

Figura 20. Esquema probable de preparación del pescado en un sitio costero en tiempos teotihuacanos antes de su traslado al centro. El tiempo requerido para el transporte de estos alimentos desde la costa de Veracruz hasta Teotihuacan hacía no solo necesaria, sino obligada su preparación, a fin de asegurar que llegaran en buenas condiciones. (Elaboró Bernardo Rodríguez).

Al paso de los años y de nuevas investigaciones no sólo se ha corroborado la propuesta, sino se ha ampliado, gracias a diversos estudios, incluidos algunos con el ADN de restos humanos y el estudio de isótopos. Estas investigaciones han permitido corroborar la importancia de los centros de barrio no sólo como organizadores de actividades en zonas de la ciudad, sino también como receptores de gente y artículos de diversas regiones. De este modo sabemos que a Teopancazco llegaron personas y productos que provenían desde la costa del Golfo hasta Guatemala y Honduras; los centros de barrio de San Francisco Mazapa y la Ventilla muestran relación étnica con 
la zona maya, en especial de la zona del Caribe y en éste último, y el centro de barrio de San Sebastián Xolalpan, interacción con regiones del oeste de la Cuenca de México.

Dentro de todo esto sin duda destaca la interacción entre Teotihuacan y la zona maya, pues ambos pueblos tenían mucho que aportar al otro y aunque las diferencias a nivel cultura y ambientes eran grandes, los beneficios eran mayores.

Toda esta presencia de regiones y culturas ajenas a lo puramente teotihuacano ha llevado a la propuesta de condición multiétnica de la ciudad, por lo que quizá se conocía bien a cada barrio o sector donde había más presencia de personas o productos provenientes de tal o cual región, no obstante también hay evidencias de integración de la población, es decir, que las diferencias de origen no evitaban que se formaran parejas provenientes de dos culturas distintas, lo cual derivaba en la fusión de formas de vida, costumbres y, sin duda, tradiciones alimentarias.

\section{Lista de las obras empleadas en la elaboración del capitulo}

$1,13,15,19,21,24,28,31,32,33,34$. 


\section{¿Todos en Teotíhuacan comían igual?}

Desde que se reconoció la condición de gran urbe de Teotihuacan surgió la pregunta ¿qué tan bien o mal alimentada estaba la población de la ciudad? Esta pregunta no necesariamente involucraba a la clase dirigente, es decir, a sacerdotes y gobernantes, pero sí a la multitud de gente normal que, ahora sabemos, vivían realizando diferentes actividades.

Sobre todo lo referente a la carne siempre hubo gran controversia, pues la cantidad de huesos de animales descubiertos, sobre todo de venados, no eran tan grande como para pensar que los teotihuacanos habían tenido una alimentación rica en proteínas animales. Medio siglo después disponemos de muchos más datos que nos permiten entender mejor este importante punto.

Posiblemente la mejor información sobre alimentación en Teotihuacan en las fases tempranas de la ciudad proviene del Templo de Quetzalcoatl, pues los entierros descubiertos, además de pertenecer a las fases Miccaotli y Tlamimilolpa, han sido objeto de múltiples estudios, entre ellos, de aspectos nutricionales. El hallazgo ocurrió en los años ochentas del siglo pasado, de modo que al paso de más de treinta años han surgido múltiples teorías acerca de lo que significó dentro de la historia y el pensamiento teotihuacano, pero ahora en el presente, gracias a estudios de ADN, integración de las investigaciones osteológicas y nuevos enfoques hay la posibilidad de utilizar la información para conocer algo de la alimentación teotihuacana en esas épocas.

El total de individuos enterrados es de 134, acomodados en grupos cuya orientación dependió de objetivos simbólicos (Figura 21), pero en cada uno quedaron presentes todas las jerarquías de la 


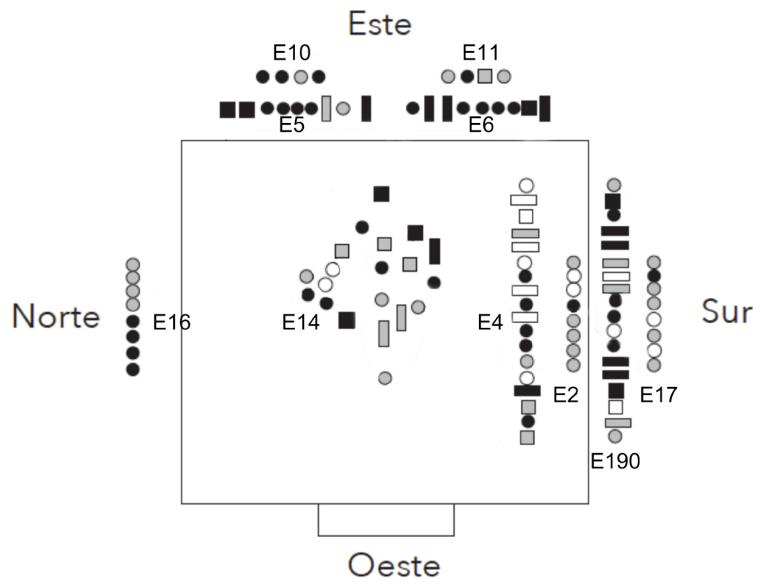

Clave:

Sin mutilación dentaria/condiciones de salud:

Buenas $\bigcirc$ Regulares $\bigcirc \quad$ Malas

Con mutilación dentaria/condiciones de salud:

Buenas $\square \quad$ Regulares $\square \quad$ Malas

Con mutilación dentaria e incrustación/condiciones de salud:

Buenas $\square \quad$ Regulares $\square \quad$ Malas

Figura 21. Entierros del Templo de Quetzalcoatl, vistos desde arriba, pertenecientes a finales de Miccaotli e inicios de Tlamimilolpa. En cada grupo de entierros hay individuos con características que denotan diferentes niveles sociales (bajo nivel: sin mutilación dental, nivel alto: hay solo mutilación dental, nivel más alto: mutilación dental con incrustación), no obstante los resultados osteológicos muestran que las condiciones nutricionales no tenían relación alguna con los niveles jerárquicos.

(Imagen de González 2016).

sociedad teotihuacana, aspecto que pudo reconocerse a través de algunos elementos distintivos presentes en los esqueletos como la presencia o ausencia de mutilación dental ${ }^{6}$.

6 Una tradición distintiva de la civilización mesoamericana fue modificar la forma de los incisivos, haciéndolos por ejemplo, triangulares o con la forma de ciertos animales como los cánidos y también podían llegarse a colocar incrustaciones en perforaciones elaboradas. El objetivo de esta práctica era recalcar los niveles sociales de una comunidad, pues se consideraba que el portador era un individuo superior del resto. 
Respecto del aspecto nutricional, 103 cuerpos fueron evaluados, 15 de los cuales mostraron buenas condiciones al momento de su muerte y 51 (49.5\%) mal estado. No obstante se constató que en general la mitad de los individuos de cada nivel jerárquico presentaba ese mismo esquema de deficiencias nutricionales e igual ocurría con los de mejor estado nutricional, es decir, la buena o mala historia alimentaria nada tenía que ver con los niveles sociales.

Con esta información podemos considerar que aunque en esa época las jerarquías eran un aspecto fundamental dentro de la sociedad teotihuacana, la calidad de la alimentación no era uno de los aspectos en los que se hacía notar, quizá sí la cantidad de alimento o la posibilidad de escoger qué comer o en qué momento, mas no el efecto sobre su organismo. Dato complementario son estudios de isótopos obtenidos de algunos de los individuos los cuales mostraron que, sin importar el nivel social, en general se alimentaban de plantas tipo C3 y que las mujeres mostraron dietas más abundantes y más ricas en carne.

Para tiempos posteriores, principalmente en tiempos Xolalpan, disponemos de mucha más información, tanto a nivel cantidad de personas analizadas, como de sitios y tipos de estudios. Veamos primero la lista de organismos que tenemos en el Cuadro $4 \mathrm{y}$ ubiquemos a las plantas y los animales cuyos restos se han recuperado y están relacionados con el alimento.

Dado que se trata de restos recuperados del contexto arqueológico, es muy difícil saber algo más que su uso en la alimentación, pues finalmente tenemos lo que sobró, no lo que se consumió, de modo que la sola presencia no garantiza ni grandes cantidades, ni abasto continuo, pero sí nos habla de una importante diversidad de alimentos; por otro lado se ha comprobado que casi la totalidad de los huesos y otros restos alimentarios terminaban en las fauces de los perros, así que lo que podemos concluir es que si a pesar de esta destrucción tenemos gran diversidad de restos, significa que la ciudad estaba adecuadamente abastecida. 


\begin{tabular}{|c|c|c|}
\hline Plantas & Maguey & Patos (varias especies) \\
\hline Amaranto & Romerito & Garzas \\
\hline Huauhtzontle & Jícama & Otras aves lacustres \\
\hline Epazote & Guayaba & Codornices (tres especies) \\
\hline Ciruela & Animales & Guajolote \\
\hline Girasol & Tlacuache & Palomas \\
\hline Calabacita & Armadillo & Tortugas casquito \\
\hline Frijol & Conejos (tres especies) & Tortugas japonesas \\
\hline Chia & Liebres (dos especies) & Serpientes diversas \\
\hline Aguacate & Ardillas (dos especies) & Lagartos diversos \\
\hline Maíz & Ardillón & Ranas, renacuajos \\
\hline Verdolaga & Tuza & Charales \\
\hline Tejocote & Rata silvestre & Pez bobo \\
\hline Capulín & Perro & Mojarras \\
\hline Chile & Pecarí & Robalos \\
\hline Xaltomata & Venado cola blanca & Huachinangos \\
\hline Tomate verde & Venado cabrito & Sardinas \\
\hline Nopal (y tuna) & Berrendo & Otros peces marinos \\
\hline
\end{tabular}

Cuadro 4. Plantas y animales relacionados con la alimentación teotihuacana.

No obstante la homogeneidad de la dieta teotihuacana, tenemos también la evidencia de espacios donde había un acceso diferenciado a ciertos recursos, por ejemplo los conejos y liebres en Oztoyahualco, productos marinos en Teopancazco, pulque en la Ventilla, por lo que también es seguro que aunque el $90 \%$ de la dieta se obtuviera del tianguis y se basara preferentemente en el maíz, siempre era posible que en cada sector hubiera algunas familias que disponían del acceso a algunos alimentos adicionales (Cuadro 5).

Los estudios con isótopos refuerzan la idea de la relevancia de este 10\% de flexibilidad alimentaria. En el centro del barrio de Teopancazco se determinó que los individuos de algunos entierros pertenecientes a la fase anterior, a Tlamimilolpa, presentaron resultados que indican gran diversidad en el origen de alimentos, es decir, que consumieron alimentos de la milpa, del bosque, del desierto, en otras palabras, plantas C3, C4 y CAM (Cuadro 5), pero también los resultados con 
elementos traza demuestran que en esta fase hubo un alto consumo de peces marinos, por los niveles de bario $(\mathrm{Ba})$ reconocidos. Al pasar a la fase Xolalpan los resultados indican que la gente se alimenta más y además hay claro dominio de alimentos relacionados con los vegetales $\mathrm{C} 4$, es decir, de maíz y animales criados en la milpa que se alimentaban de esta planta, disminuyendo el consumo de peces marinos. Esto coincide con la idea de un tianguis abastecido por productos derivados de las milpas y criaderos. En la fase siguiente, Metepec, la alimentación regresa al esquema Tlamimilolpa, con fuerte presencia de plantas silvestres y del bosque, quizá una evidencia de que la producción y el abasto ya no eran suficientes (Cuadro 5).

\begin{tabular}{|c|c|c|c|}
\hline $\begin{array}{c}\text { Años de } \\
\text { Nuestra Era }\end{array}$ & Fase & Sistemas de abasto & Esquema alimentario \\
\hline 650 & Metepec & $\begin{array}{l}\text { Probablemente abasto } \\
\text { derivado de la } \\
\text { organización de grupos }\end{array}$ & $\begin{array}{l}\text { Se regresa al esquema } \\
\text { Tlamimilolpa o Miccaotli. }\end{array}$ \\
\hline & Xolalpan & $\begin{array}{l}\text { Sistema de abasto a la } \\
\text { ciudad controlado por el } \\
\text { gobierno central, a través } \\
\text { de tianguis organizados en } \\
\text { los centros de barrio. }\end{array}$ & $\begin{array}{l}\text { Basado en los productos animales } \\
\text { y vegetales de la milpa, así como } \\
\text { de otros cultivos, de crianza } \\
\text { especializada y aquella } \\
\text { procedentes de otras regiones. }\end{array}$ \\
\hline 350 & Tlamimilolpa & $\begin{array}{l}\text { Sistema de abasto a partir } \\
\text { de la organización de } \\
\text { sectores o grupos. }\end{array}$ & $\begin{array}{l}\text { Productos de la milpa, del } \\
\text { bosque, del desierto, de zonas } \\
\text { lacustres, a veces productos } \\
\text { marinos. }\end{array}$ \\
\hline $\begin{array}{l}100 \\
0\end{array}$ & $\begin{array}{l}\text { Miccaotli } \\
\text { Tzacualli }\end{array}$ & $\begin{array}{l}\text { Sistema de abasto a partir } \\
\text { del esfuerzo individual. }\end{array}$ & $\begin{array}{l}\text { Productos de la milpa, del } \\
\text { bosque, del desierto, de zonas } \\
\text { lacustres. }\end{array}$ \\
\hline
\end{tabular}

Cuadro 5. Posibles sistemas de abasto y esquemas alimentarios al interior de la ciudad de Teotihuacan, durante las diferentes fases. (Elaboró Raúl Valadez).

Respecto de estudios osteológicos y los marcadores de mala nutrición, los resultados varían de un sitio a otro, pero en términos generales se concluye siempre que en las colecciones estudiadas hay individuos bien alimentados, mal alimentados y aunque en algunos 
casos se observan deficiencias nutricionales severas, se ve también que sobrevivieron a ellas, o vivieron con ellas, durante muchos años. Todo ello nos indica que las diferencias podían ser producto de circunstancias individuales y también, muy probablemente, de circunstancias sociales, pero la mala alimentación no fue algo generalizado como se podría pensar.

Sin duda, uno de los aspectos más involucrados con la calidad alimentaria de una persona es el acceso a la proteína animal, a la carne, ya que constituye, a su vez, una fuente necesaria para que el cuerpo construya sus propias proteínas, base del óptimo desarrollo y funcionamiento del cuerpo. No obstante sabemos que las que requerimos también pueden obtenerse de plantas, por lo que una dieta equilibrada puede construirse sin necesidad de mucha carne.

Regresemos a la gráfica de la Figura 18. Hemos visto a través de ella la homogeneidad que se manifiesta en la muestra de teotihuacanos con respecto a personas de épocas posteriores, pero también permite ver qué tan presente estaba la carne en su dieta. La colocación de estas personas en la parte inferior de la misma deja ver también que no comían mucha carne, incluso sus valores promedio se asemejan a los de los tlacuaches, es decir, que muchos teotihuacanos tenían un régimen alimentario equivalente al de un tlacuache. ¿Qué significa esto? Veamos cuál es la dieta de esta especie (Figura 22).

Como podemos apreciar en la información presentada, la dieta de este animal se encuentra dentro de los estándares humanos, bien podríamos calificarla de sana, pero además muy acorde con lo que hemos visto, es decir, gran cantidad de vegetales, incluido el aguamiel (y el pulque) complementado con alimentos diversos de origen animal, desde insectos hasta vertebrados. Esto también conduce a la idea de que los problemas nutricionales que se han detectado en individuos o grupos estarían vinculados principalmente a circunstancias personales, quizá en muchos casos más que a las clases sociales y a aspectos económicos. 


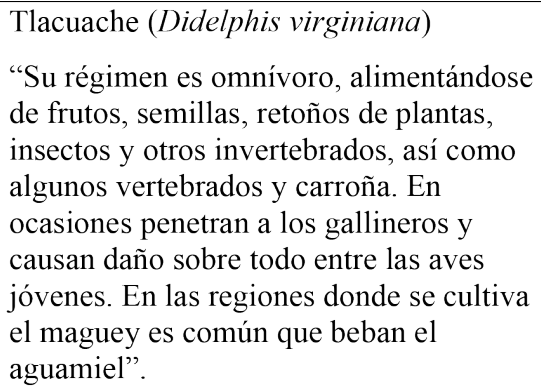

Figura 22. Alimentación del tlacuache e imagen de éste. Los estudios de elementos traza muestran gran semejanza entre su patrón alimentario y el de los teotihuacanos, condición lógica por ser especies omnívoras (texto Ceballos y Galindo 1984, fotografía https://www.elsoldeleon.com.mx/local/el-tlacuache-una-especiemuy-discriminada).

Al sur de la ciudad hay una unidad habitacional llamada Tlajinga 33 (Figura 4), donde se hicieron estudios osteológicos de los individuos descubiertos y de la fauna registrada. Estas personas trabajaban oficios como la lapidaria y la cerámica y la temporalidad del sitio iba desde Tlamimilolpa hasta Metepec. Se consideró que este espacio estuvo ocupado por gente de bajo nivel socioeconómico.

Para el final de Xolalpan y Metepec corresponden resultados que indicaron condiciones de salud complicadas para los niños. Los datos de los huesos señalan crecimiento lento o nulo, debido a la desnutrición, incluso desde que eran fetos y hasta los cinco o seis años. La fauna asociada eran principalmente especies pequeñas, conejos, codornices, patos, tortugas, víboras, peces y huevos. Sin duda los insectos, reptiles, tortugas y peces los conseguían a bajo costo, pues son animales que incluso podrías atrapar en los ríos que recorren el valle o saliendo de la ciudad. Sabemos que su valor como alimento no es malo, incluso los insectos tienen una gran importancia como fuentes de proteínas, pero quizá la cantidad que se obtenía era insuficiente para alimentar a todos y, para este sitio, eran los niños quienes debían sobrellevar las limitaciones. 
Toda esta información es importante en cuanto a que nos muestra que muchos de los teotihuacanos podían estar limitados en cuanto a que podían o no comer, bien fuera porque su condición social era un impedimento o bien porque su situación económica no les permitía tener acceso a determinados alimentos, no obstante, a fin de cuentas, muchas veces era posible disponer de una dieta que les proporcionara los nutrientes adecuados para mantener una condición de salud suficiente para realizar su vida de manera normal, ya fuera un artesano, un guerrero, un sacerdote o un trabajador de un taller. Muy probablemente un individuo de alto nivel podría acceder al alimento que deseara directamente del tianguis o disponer de quien le abasteciera de forma particular, en tanto que uno de condición muy humilde tal vez debía hacer jornadas fuera de la ciudad para colectar alimento, por ejemplo insectos, algunas aves, ardillas y conejos, y sólo lo más indispensable, el maíz, lo obtendría en el tianguis.

Las personas con un buen nivel de nutrición las encontramos en casi todos los ámbitos teotihuacanos, aunque en menor proporción. $\mathrm{Si}$, como hemos visto, las jerarquías sociales o el nivel económico no es determinante para relacionarlo con su condición nutricional, entonces quizá todo dependía de su historia de vida, principalmente dentro de sus primeros años. Si pensamos en un habitante de la ciudad que había vivido de niño en un periodo de enorme plenitud climática, sin duda se habría beneficiado por las abundantes cosechas y ello le habría ayudado a desarrollarse muy bien, aunque fuera de origen humilde; pero si ocurrió lo contrario, que a un niño le tocó vivir en un tiempo de sequías generalizadas, sin duda habría tenido limitaciones en su alimentación con las respectivas consecuencias, aunque pertenecieras a una familia de la élite.

Quizá el mayor contraste entre las fases Tlamimilolpa y Xolalpan en lo que a nutrición se refiere, es que en la primera fase, la muestra del Templo de Quetzalcoatl indica 50\% de malas condiciones, en tanto que los estudios para el periodo posterior, indican mayor cantidad de individuos con un mejor estado nutricional, por ejemplo 
en Oztoyohualco (Xolalpan tardío), una persona con problemas nutricionales frente a un total estudiado de cuarenta, quizá todo esto producto de la organización de la ciudad y de la época de auge que se vivía, lo cual beneficiaba a todos.

Con lo que hemos visto es posible concluir que en Teotihuacan, como en cualquier ciudad del mundo antiguo, existían personas mejor y peor alimentadas, así como enfermedades por desórdenes nutricionales derivados de problemas de higiene y porque no todo mundo tenía igual acceso a la comida. En los tiempos antiguos pareciera que la población dependía más del esfuerzo personal o grupal, y los beneficios nutricionales no siempre estaban a la altura. Posteriormente y quizá como respuesta al crecimiento de la urbe, el gobierno teotihuacano buscó medios para que la población tuviera un acceso más sencillo a los alimentos y aparentemente eso ayudó a que, en términos generales, la población viviera con menos problemas nutricionales, producto del abasto y de la posibilidad de poseer una dieta, basada en el maíz sí, pero suficientemente diversa para considerarla sana.

\section{Lista de las obras empleadas en la elaboración del capitulo}

$4,5,7,8,9,10,12,14,15,16,17,18,19,24,27,31,32,33,35,37,39,40,43,44$, 46, 47, 49.

\section{Páginas electrónicas relacionadas con imágenes}

AlfonsinoDazMar (24/08/2017) El tlacuache, una especie muy discriminada, El Sol de León, https://www.elsoldeleon.com.mx/local/ el-tlacuache-una-especie-muy-discriminada (consultada el 24 de agosto de 2017). 


\section{El final de la buena alimentación}

A lo largo de la obra hemos visto las características principales de lo que fue la alimentación al interior de la ciudad de Teotihuacan y su evolución respecto de los sistemas de abasto, los tianguis, la obtención y elaboración del alimento. Para mediados del primer milenio de nuestra Era, en tiempos Xolapan, sin duda la ciudad era un ejemplo de organización y la envidia de otras ciudades mesoamericanas.

Dentro de lo que hemos visto, tenemos que para tiempos antiguos se vive un sistema más basado en la autosuficiencia, tanto en la producción como en la elaboración de alimentos; posteriormente se crea el sistema de organización teotihuacano que abarcó arquitectura monumental y habitacional, organización de la ciudad, esquemas productivos dentro y fuera de la ciudad, sistemas de abasto, tianguis y los ajustes respectivos al interior de las unidades habitacionales en lo que a elaboración y consumo de alimento se refiere. En este periodo se consolidan patrones alimentarios basados en los productos agrícolas, sobre todo maíz, y en otros provenientes también de la milpa; sin duda se había llegado al máximo nivel en cuanto a lo que significa un programa organizado en la producción y abasto de alimento para una población de 150,000 habitantes. ¿Disminuyó en ese periodo la población mal alimentada? Aparentemente sí y eso haría que la mayoría de la gente se encontraría satisfecha.

Para la fase Metepec no hay muchos datos, pero lo existente deja ver una evidente caída. La actividad arquitectónica es muy limitada, las manifestaciones a nivel de los edificios, las pinturas, muestran poca diversidad, poco esfuerzo, como si ya no hubiera ideas, tiempo, o recursos. Al parecer ya no se tiene control sobre las importantes minas de obsidiana. Los restos animales $\mathrm{y}$ vegetales muestran poca abundancia y diversidad con una 
limitada o nula ausencia de productos foráneos; datos de diversas fuentes hablan de una alimentación en la cual los productos agrícolas ya no tienen la fuerza de antes y se debe recurrir a los alimentos silvestres, como si se viviera en un pequeño pueblo, y los problemas alimentarios parecen ser más comunes.

¿Qué ocurrió en el paso de Xolalpan a Metepec que diera lugar a este cuadro por demás deprimente?

Circunstancias que aún no quedan claras, quizá tensiones sociales al interior de la ciudad; quizá la llegada de nuevos grupos humanos a los que no les interesa incluirse en la sociedad teotihuacana, sino solo obtener beneficios; quizá la competencia con otras ciudades, quizá la pérdida de las principales fuentes de recursos, quizá conflictos y luchas por el poder dentro del grupo gobernante.
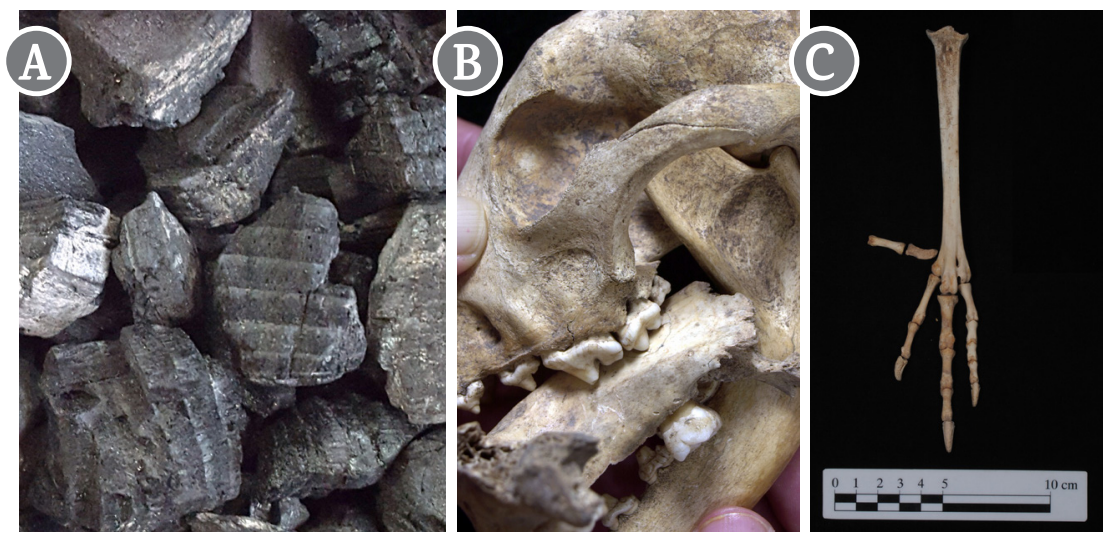

Figura 23. Ejemplos de evidencias del conflicto social que se dio en Teotihuacan al final de la fase Xolalpan, provenientes del centro de barrio de Teopancazco. (A), restos de carbón derivado de vigas de madera quemados, evidencia del incendio que se dio en el lugar; (B), fragmento de mandíbula inferior humana mostrando los sitios donde fue mordida por un perro, evidencia de que se trató de un entierro saqueado y dejado a la intemperie. (C), una de las dos patas de guajolote íntegras, que se encontraron colocadas junto a un vaso estrellado, como parte de un rito de terminación.

(Fotografía A de Diana Martínez, fotografías B y C de Rafael Reyes). 
Algunas o todas estas causas y otras que no conocemos provocaron que en el 550 de nuestra Era, al final de la fase Xolalpan, se diera lugar a fuertes conflictos sociales que derivaron en incendios provocados en varios edificios (Figura 23A) hasta el punto de que parte de la ciudad quedó en caos por un tiempo determinado, llevando al vandalismo, a la profanación de tumbas, dejando todo de forma que los perros pudieran establecerse en esas unidades y pasar el tiempo mordisqueando los restos dejados al azar (Figura 23B). Al interior de las unidades habitacionales o los centros de barrio se observan evidencias de abandono (Figura 24), ritos que involucran la terminación (Figura 23C), el final, a veces con claras manifestaciones de molestia, de desear el mal para quienes pisaran esos sitios en el futuro.

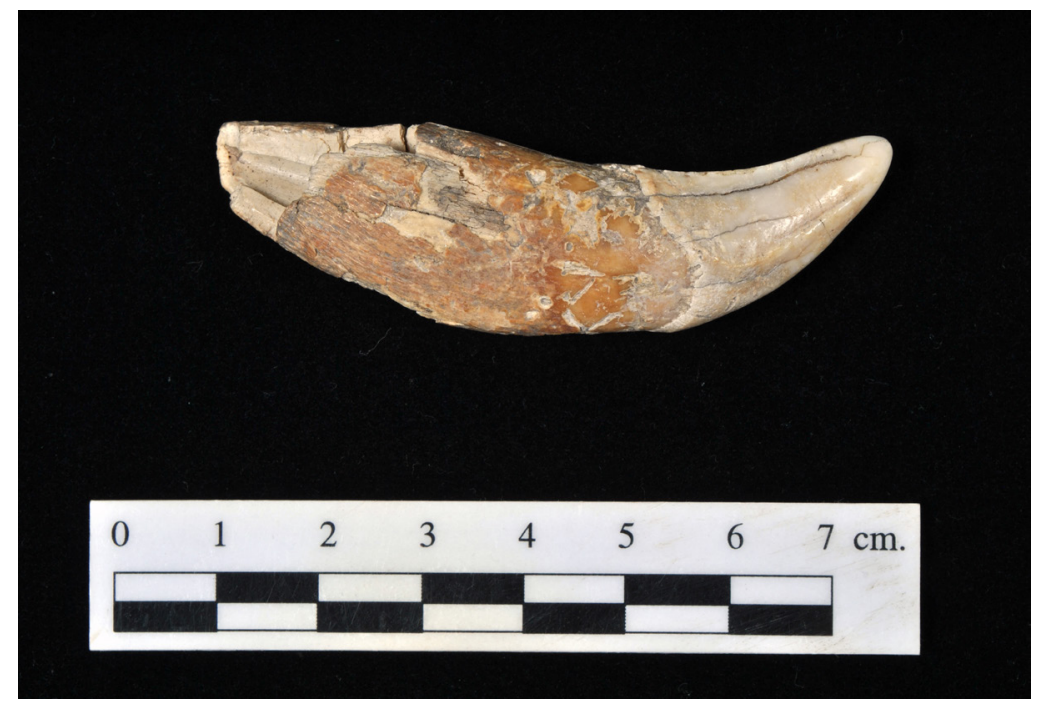

Figura 24. Colmillo de jaguar descubierto en la unidad habitacional de Oztoyahualco junto a una fosa dentro del llamado C39. Implementos asociados a la elaboración de dicha fosa quedaron a un lado, todo esto indicando que la unidad fue abandonada antes de que el acto ritual que involucraba la colocación de este colmillo, fuera concluido. (Fotografía de Rafael Reyes). 
No obstante la magnitud del conflicto, la ciudad lo superó y mantuvo su integridad por 100 años más. Sin embargo, sus estructuras de organización estaban rotas e incluso hay quienes opinan que ya no existía un gobierno central. Bajo estas circunstancias sus pobladores debieron regresar a las formas antiguas, es decir la autosuficiencia, que para el caso de lo alimentario implicaría producir y proveerse a partir de sus propios medios, quizá trabajando en grupo, quizá aún manejando en tianguis los productos que se elaboran en los diferentes sectores o las diferentes personas, pero sin probabilidad alguna de que se manifestara la abundancia y los beneficios de antaño.

\section{Lista de las obras empleadas en la elaboración del capitulo}

14, 15, 19, 21, 28, 43, 47. 


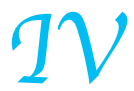

\section{APRENDIENDO \\ de la experiencia teotínuacana}




\section{El legado teotíhuacano en la actualidad}

T os estudios interdisciplinarios en Teotihuacan, alrededor del tema _de la alimentación continúan, siempre en la búsqueda de nueva información que permita mejorar lo que actualmente conocemos. Por ejemplo, un estudio reciente de un molcajete prehispánico con fondo estriado, de época posterior, se encontró una abundante presencia de proteínas, cuando lo esperado serían restos de carbohidratos y vitaminas, como corresponde a los vegetales que generalmente se muelen para la preparación de salsas. Una probable explicación es la posibilidad de que al momento en que se elaboraba la mezcla, además de los ingredientes tradicionales, se incluyeran insectos, base de las proteínas detectadas, y que no sólo las haría más sabrosas, sino también más nutritivas.

Algo que sigue siendo un tema relevante dentro de los estudios de la alimentación teotihuacana es la tortilla, sobre todo por ser un alimento que nos identifica actualmente, pero que para tiempos teotihuacanos, aparentemente, todavía no existía. No sabemos si ello es el resultado de que aún no se había perfeccionado el sistema de nixtamalización ${ }^{7}$ y todavía no era posible preparar una masa adecuada para producir las películas circulares flexibles que ahora conocemos como tortillas. También es probable que el instrumento básico para ello, el comal, aun no se hubiera inventado. En todo caso se trata de un tema que forma parte de los objetivos a cubrir en futuros estudios.

Hace menos de veinte años que se identificaron los primeros restos de peces marinos en contexto teotihuacano y definitivamente la repercusión de esto es enorme, pues las especies reconocidas: huachinangos, mojarras, robalos, peces bobo y otros más, forman

\footnotetext{
7 Proceso mediante el cual los granos de maíz se dejan en agua con cal durante la noche, a fin de ablandar la cubierta del grano y así poder molerlo más fácilmente al día siguiente para la elaboración de la masa. El empleo de la cal favorece también la liberación y aprovechamiento de algunos aminoácidos esenciales para el cuerpo humano, aumentando así las propiedades nutricias de esta planta.
} 
parte de nuestra cocina tradicional desde hace mucho tiempo, por lo que posiblemente tenemos, en estas evidencias, los casos más antiguos conocidos al respecto.

Otro aspecto interesante es la presencia en Teotihuacán del aguamiel y el pulque que desde tiempos remotos han acompañado a las culturas del centro del país. En este momento nuestra sociedad ha menospreciado esta bebida en parte debido a las campañas de desprestigio orquestadas por las empresas cerveceras y que han creado leyendas negras de insalubridad para poder desplazar esta bebida de la preferencia de los mexicanos, pero lo cierto es que se trata de una bebida de gran valor nutricional que forma parte de nuestro legado, siendo el único aspecto a considerar la forma como es adecuado consumirlo, como cualquier otro alimento o bebida que exista en el mundo.

En diversos tianguis del centro y zona oriente de México podemos encontrar peces que se venden ahumados y envueltos en hojas de maíz, para así facilitar tanto su preservación como su traslado. Sin duda este esquema de manejo existió en tiempos teotihuacanos, pues de otra forma no es posible imaginar de qué manera podrían haberse conservado aptos para su traslado y consumo en jornadas de varios días de duración. Este constituye también un importante tema de investigación, pues todo su proceso de manejo, desde su pesca, su preparación, ya fuese por salado, secado al sol o ahumado, su acomodo apilado en columnas y su traslado lo podemos ver en el presente, pero proveniente de un origen muy antiguo.

Sin duda un tema motivo de sorpresa para muchos lectores fue la presencia de tianguis al interior de Teotihuacan. Ciertamente este esquema de mercado es sencillo, práctico y muy relevante en su funcionamiento y repercusión a nivel alimentario y económico (Figura 25). Por lo mismo no es de extrañar que podamos concluir que la adquisición de los productos en un tianguis del presente siga pautas que bien podrían remontarse a los tiempos Teotihuacanos, donde los productores ofrecen por lo menos una vez a la semana sus 
productos de manera directa, sin intermediarios, y frecuentemente intercambian mercancía con otros comerciantes o productores. Su eficiencia y la familiaridad de la sociedad mexicana a este sistema es grande y por ello inclusive en las grandes urbes se ha desarrollado el moderno tianguis itinerante que va de barrio en barrio por toda la ciudad ofreciendo los productos básicos, quizá un esquema que ponemos a funcionar en el presente a partir de nuestra memoria social ligada a nuestro pasado prehispánico.
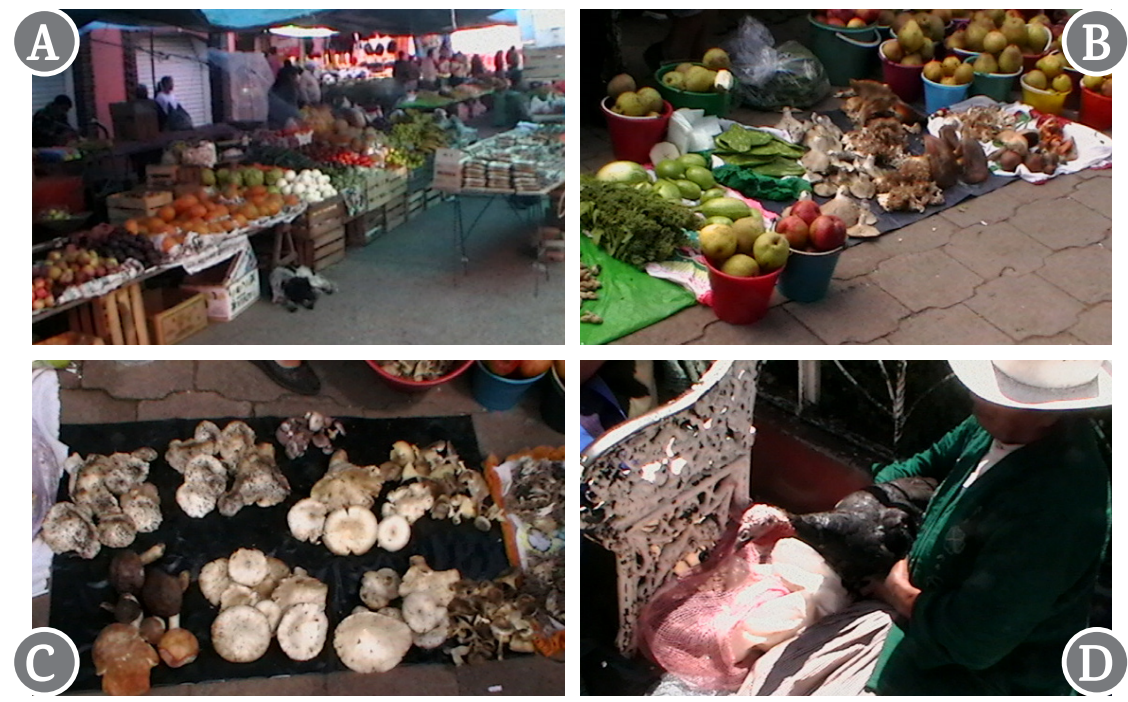

Figura 25. Cuatro escenarios del tianguis del domingo en la ciudad de Acaxochitlán, Estado de Hidalgo, con los cuales podemos ver su organización básica (A) y los alimentos que se ofrecen producto del cultivo (B), de la colecta (C) y de la crianza (D). Como en muchos lugares de México, se realiza en las cabeceras municipales o en ciudades donde su tamaño y ubicación permite el acceso de gente de localidades cercanas con el fin de vender sus productos y adquirir otros, aprovechando la diversidad y cantidad de personas, intereses y mercancía disponible. Este esquema de organización bien puede ser el mismo que se dio en Teotihuacan hace mil quinientos años (Fotografía de Raúl Valadez). 


\section{Reflexiones finales}

Como se indicó al inicio, la obra pretende mostrar el conocimiento actual de lo que habría sido el esquema alimentario teotihuacano para poder formarnos una idea acerca de cómo se vivía en una ciudad mesoamericana. Ya vimos que buena parte de lo descrito es compatible con nuestra vida cotidiana y que, ahora sabemos, forman parte de nuestras tradiciones en la alimentación, lo cual, básicamente, nos muestra que dicho acervo se encuentra tan inmerso en nuestras raíces culturales como un nopal a la tierra.

Hoy en día seguimos conservando muchos de los elementos que constituían la alimentación que se ha reconocido en Teotihuacan y hemos tenido la oportunidad de conocer; hay cambios, sin duda, por ejemplo la llegada de nuevos productos que han transformado el proceso de preparación de alimentos, pero en esencia se sigue conservando un esquema alimentario con un conjunto básico de alimentos y una concepción similar de lo que se come y cómo se come.

Por tratarse de dietas oriundas de esta región, producto de la relación hombre-naturaleza desde tiempos remotos, son claramente diferentes de lo europeo, y es por ello que en algunas épocas han sido puestas en duda respecto de su valor nutricional, pero lo cierto es que un patrón alimentario basado en un conjunto grande de vegetales, empezando por el maíz, complementados con otros alimentos como la carne, la miel, el pescado, los hongos, por solo mencionar algunos, ha demostrado por siglos ser óptima, permitiendo a millones de personas alimentarse de manera adecuada y que dependiendo de sus condiciones particulares les permitió estar sanos y ser productivos. Como en todas las sociedades humanas siempre habría altos y bajos de estatura, fuertes y débiles, flacos y gordos, pero dentro de esta variedad, la gran mayoría podía cubrir sus necesidades básicas 
y vivir sin los recursos médicos y hospitalarios que ahora nos vemos obligados a utilizar.

Esto último no es poca cosa, pues en la actualidad enfrentamos una crisis con nuestra alimentación, en la medida en que hemos dejando de lado las enseñanzas del pasado y se han introducido alimentos industrializados, promovidos por compañías transnacionales de alimentos, cuyos contenidos de grasas y azúcares poco a poco están mermando a nuestra población por los graves problemas de salud que ocasionan. En aproximadamente 30 años se ha transformado nuestra alimentación, abandonando buena parte de nuestros alimentos tradicionales y gracias a ello ahora ocupamos uno de los primeros lugares de obesidad y diabetes en el mundo.

Dado que esta crisis alimentaria que deteriora a nuestra sociedad es algo ya reconocido por el mundo médico nacional, es claro que debemos cambiar el rumbo no en un futuro cercano, sino de inmediato y para ello nada más sencillo que volver nuestros ojos a las experiencias de nuestros antepasados, las cuales tenemos a nuestro alcance gracias al trabajo de investigadores y a la aplicación de las ciencias para estudiar la alimentación en el pasado y aprovechar este conocimiento para tener más conciencia de nuestra alimentación y más control sobre nuestra salud. Tenemos en nuestras manos lo necesario para hacerlo, depende de nosotros dar el paso. 
$\frac{\mathcal{V}}{\text { BIBLIOGRAFÍA }}$ 
1. Aguirre, A., B. González, B. Álvarez, C. Serrano y A. Meza 2017 Genetic History of Classic period Teotihuacan burials in central Mexico, Revista Argentina de Antropología Biológíca 19(1):1-14.

2. Barba, L., B. Ludlow, L. Manzanilla y R. Valadez

1987 La vida doméstica en Teotihuacan: un estudio interdisciplinario, Cíencía y Desarrollo 77(XIII):21-32.

3. Biskowski, M.

2917 Staple food preparation at Teotihuacan, Archaeol Anthropol Scí, 9:29-38, DOI 10. 1007/s12520-016-0421-1.

4. Casar, I., P. Morales, L. Manzanilla, E. Cienfuegos y F. Otero 2017 Dietary differences in individual buried in a multiethnic neighborhood in Teotihuacan: stable dental isotopes from Teopancazco, Archaeol Anthropol Sci, 9:99-115, DOI 10. 1007/s12520-016-0422-0.

5. Ceballos, G. y C. Galindo

1984 Mamiferos sílvestres de la Cuenca de Méxíco. Editorial Limusa, México.

6. De la Fuente, B. (Coordinadora)

$1996 \mathcal{L} a$ pintura mural prefispánica en México. $\mathcal{I}$. Teotîhuacan, Instituto de Investigaciones Estéticas de la Universidad Nacional Autónoma de MéxicoInstituto Nacional de Antropología e Historia, México.

7. Genovés, S.

1966 Nuevas tablas para la reconstrucción de la estatura en restos mesoamericanos, Cuadernos Americanos 19, Universidad Nacional Autónoma de México, México. 
8. González, B.

$2016 \mathcal{E l}$ cuerpo como vestígio biológico, simbólico y social. Victimas sacrificadas en el Templo de Quetzalcoatl en Teotíhuacan, Instituto de Investigaciones Antropológicas, Facultad de Filosofía y Ciencias, División de Estudios de Posgrado de la Universidad Nacional Autónoma de México, México.

9. Goodman, A. y D. Martin

1993 Reconstructing health profiles from skeletal remains, en Richard Steckel, Jerome Rose y Paul Sciulli (eds.), History of health and nutrition in the western hemisphere, Ohio State University, Columbus, Ohio: 2-109.

10. Goodman, A., D. Martin, G. Armelagos y G. Clark

1984 Indications of stress from bone and teeth, en Mark Cohen y George Armelagos (eds.), Paleopathology at the origins of agrículture, Academic Press, Orlando, Florida: 13-49.

11. Goodman, J

1993 La respuesta inmunitaria, en D. Stites y Abba Terr (eds.), Inmunología básica y clínica, El manual Moderno, México: 35-46.

12. López, L. y G. Olivier (Coordinadores)

$2010 \mathcal{E}$ l sacrificio humano en la tradición relígiosa mesoamericana, Instituto Nacional de Antropología e Historia, Universidad Nacional Autónoma de México, México. 
13. Manzanilla, L. R

2017 Discussion: the subsistence of the Teotihuacan metrópolis, Archaeol Anthropol Sci, 9:133-140, DOI 10. 1007/s12520-016-0418-9.

14. Manzanilla, L. R. (Editora)

1993 Anatomia de un conjunto residencial teotíhuacano en Oztoyahualco, Instituto de Investigaciones Antropológicas de la Universidad Nacional Autónoma de México, México.

15. Manzanilla, L. R. (Editora)

2012 Estudios arqueométricos del centro de barrio de Teopancazco en Teotíhuacan, Coordinación de la Investigación Científica, Coordinación de Humanidades, Universidad Nacional Autónoma de México, México.

16. Manzanilla, L. R. y C. Serrano (Editores)

1999 Prácticas funerarias en la Ciudad de los Dioses. Los entierros humanos de la antígua Teotíhuacan, Instituto de Investigaciones Antropológicas, Dirección General de Apoyo al Personal Académico de la Universidad Nacional Autónoma de México, México.

17. Manzanilla, L. R y L. López (Coordinadores)

2014 Historía antígua de Méxíco, vol. I-IV, serie Historia, Instituto de Investigaciones Antropológicas de la Universidad Nacional Autónoma de México, CONACULTA, Editorial Porrúa, México. 
18. Manzanilla, L. R., Bernardo Rodríguez, Gilberto Pérez y Raúl Valadez 2011 Arqueozoología y manufactura de vestimentas rituales en la antigua ciudad de Teotihuacan, México, Arqueología, 17: 221-246.

19. Manzanilla, L. (Editora) y R. Valadez (Coordinador) $2017 \mathcal{E}$ l uso de los recursos naturales en un centro de barrio de Teotífuacan: Teopancazco, Instituto de Investigaciones Antropológicas de la Universidad Nacional Autónoma de México, México.

20. Martínez, D. y C. Adriano y N Sugiyama

2016 La cita es entre el Sol y la Luna: la importancia de la chia en contextos rituales del centro cívico ceremonial de Teotihuacan, Reunión Annual de la Unión Geofísica Mexicana, Mexico.

21. Martínez, D., C. Adriano y E. Ibarra

2017 De lo cotidiano y lo sagrado: las plantas y sus usos en un centro de barrio teotihuacano, L. R. Manzanilla (ed.), R. Valadez (cord.), $\mathcal{E}$ l uso de los recursos naturales en un centro de Garrío de Teotíhuacan: Teopancazco, Instituto de Investigaciones Antropológicas de la Universidad Nacional Autónoma de México, México.

22. McClung, E.

1977 Recientes estudios paleoetnobotánicos en Teotihuacan, México, Anales de Antropología 14:49-61.

23. McClung, E. y D. Martínez

2017 The potencial of paleoethnobotanical evidence for the study of Teotihuacan foodways, Archaeol Anthropol Sci 9:39-50, DOI 10. 1007/s12520-016-0414-Z. 
24. Mejía, Gabriela

2012 Elementos traza aplicados al análisis de la paleodieta, L. R. Manzanilla (ed.) Estudíos arqueométrícos del centro de Garrío de Teopancazco en Teotíhuacan, Coordinación de la Investigación Científica, Coordinación de Humanidades, Universidad Nacional Autónoma de México, México:325-346.

25. Millon, R.

1973 Teotihuacan, Scientific American 216(6):38-48.

26. Millon, R.

1994 The place where time began: An archaeologist's interpretation of what happened in Teotihuacan history, en Kathleen Benin y Esther Pasztory (eds.), Teotifuacan. Art from the city of the gods, Thames and Hudson, Londres: 16-43.

27. Nado K., N. Zolotova y K. Knudson

2017 Paleodietary analysis of the sacrificial victims from the Feathered Serpent Pyramid, Teotihuacan, Archaeol Anthropol Sci 9:117-132, DOI 10. 1007/s12520016-0416-y.

28. Ortiz, A.

2015 Determinación de las características de un barrio teotíhuacano con arqueometría. $\mathcal{E}$ l caso de Teopancazco, Tesis Doctoral. Facultad de Filosofía y Letras, Instituto de Investigaciones Antropológicas de la Universidad Nacional Autónoma de México, México. 
29. Pérez, G.

2013 La producción artesanal vista a través del hueso trabajado en Teotíhuacan (100 $\delta C$ al $650 \delta C$ ), Tesis Doctoral de Antropología, Facultad de Filosofía y Letras-Instituto de Investigaciones Antropológicas, Universidad Nacional Autónoma de México, México.

30. Rattray, E.

2000 Teotihuacan: ceramic, cronología y tendencias culturales, Serie Arqueología de México, Instituto Nacional de Antropología e Historia, University of Pittsburgh, México.

31. Robertson, I. y M. O. Cabrera

2017 Teotihuacan Pottery as evidence for subsistence practices involving maguey sap, Archaeol Anthropol Sci 9:11-27, DOI 10. 1007/s12520-016-0415-z.

32. Rodríguez, B. y R. Valadez

2013 Vestigios del recurso costero en el sitio arqueológico de Teopancazco, Teotihuacan, Estado de México, 43(1): 9-29, revistas.ucm.es/index.php/REAA/article/ view/42294.

33. Rodríguez, B. y R. Valadez

2014 Recursos Costeros en la Ciudad de los Dioses, Götz, Ch. y K. Emery (editores), La arqueología de los animales de Mesoamérica, Lockwood Press, Atlanta, Georgia-USA: 51-82.

34. Sahagún, B.

1979 Códíce Florentino, Secretaría de Gobernación, México D.F. 
35. Somerville, A., N. Sugiyama y L. Manzanilla

2017 Leporid management and specialized food production at Teotihuacan: stable isotope data from cottontail and jackrabbit bone collagen, Archaeol Anthropol Sci 9:83-97, DOI 10. 1007/s12520-016-0420-z.

36. Starbuck, D.

1975 Man-Animal Relationship in Pre-Columbian Central Mexico. Ph.D. Dissertation, Yale University, Department of Anthropology.

37. Storey, R.

1992 Life and death in the ancient city of Teotihuacan. $\mathcal{A}$ modern paleodemographic synthesis, The University of Alabama Press, Alabama.

38. Stuart-Macadam, $\mathrm{P}$,

1991 Porotic hiperostosis: Changing interpretations, en Donal Ortner y Arthur Aufderheide (eds.), Human paleopathology, Smithsonian Institution Press, Washington.

39. Sugiyama, N. y A. Somerville

2017 Feeding Teotihuacan: integrating approaches to studying food and foodways of the ancient metropolis, Archaeol Anthropol Scí 9, DOI 10. 1007/s12520-016-0419-8.

40. Sugiyama, N. R. Valadez y B. Rodríguez

2017 Faunal acquisition, maintenance, and consumption: how the Teotihuacanos got their meat, Archaeol Anthropol Sci 9:61-82, DOI 10. 1007/s12520-016-0387-z. 
41. Taube, K.

2017 El Templo de Quetzalcóatl y el culto de la guerra sagrada en Teotihuacan, http://www.mesoweb. com/es/articulos/Taube/Quetzalcoatl-imprimir.pdf, (consultado del 7 de agosto de 2017).

42. Tortora, G. y N. Anagnostakos

1984 Principios de anatomía y físiología, Harla, México.

43. Valadez, R.

1992 Impacto del recurso faunístico en la sociedad teotíhuacana, Tesis Doctoral de Ciencias Biológicas, Facultad de Ciencias, Universidad Nacional Autónoma de México, México.

44. Valadez, R. (Editor)

2014 Alimentación y Cultura en México, Anales de Antropología 48-1, Instituto de Investigaciones Antropológicas de la Universidad Nacional Autónoma de México.

45. Valadez, R. (Editor)

2016 Viaje al Inframundo: Las ciencias y la muerte. Red de Ciencias Aplicadas a la Investigación y Conservación del Patrimonio Cultural, Instituto de Investigaciones Antropológicas de la UNAM, CONACyT, México.

46. Valadez, R. y S. Tejeda

2005 Modelo para la determinación de patrones alimentarios en poblaciones prehispánicas del centro de México a través de la cuantificación de elementos traza, En: Pifferetti, A. y R. Bolmaro (editores), Prímer Congreso Argentino de Arqueometría, Humanidades y Artes Ediciones: 290-299. 
47. Valadez, R. y B. Rodríguez 2013

Perros, tafonomía y el estudio de un caso, Revista de la Asociación Mexicana de Médicos Veterinarios Especialistas en Pequeñas Especies 24(1):5-13.

48. Vester, F. $1978 \mathcal{E}$ [ fenómeno estrés, Plaza \& Janés, Barceona.

49. Widmer, R. y R. Storey 2017

Skeletal healt and patterns of animal food consumption al S3W1:33 (Tlajinga 33), Teotihuacan, Archaeol Anthropol Scí 9:51-60, DOI 10. 1007/s12520-016-0417-z. 


\section{Entre alímentos y tradiciones EN LA CIUDAD DE LOS DIOSES}



A todos nos resulta claro que la alimentación es fundamental para la supervivencia. Pero cuando se habla del desarrollo cultural es indispensable que la población disponga de alimentos de buena calidad y en cantidad suficiente para pasar del nivel de subsistencia a un nivel en donde sin la preocupación de conseguir el alimento diario algunas personas puedan dedicarse a otras actividades que permitan acumular conocimiento, desarrollar tecnología o establecer la relación con los dioses.

En Mesoamérica fue el maíz el que favoreció el desarrollo de las culturas que conocemos. A diferencia del consumo de otros granos, el maíz requiere del tratamiento de nixtamalización para poder aprovechar todo su potencial. Este desarrollo tecnológico permitió el aprovechamiento intensivo del maíz a través de una gran variedad de productos comestibles que han trascendido el tiempo, entre ellos los tamales, el pinole, el pozol como bebida, la tortilla con todos sus derivados, el pozole como platillo combinado, etc.

En el transcurso de medio siglo se ha acumulado información científica sobre la forma en que los habitantes de Teotihuacán lograron aprovechar no solo el maíz sino muchos otros alimentos para construir su gran ciudad y mantener funcionando ese primer ejemplo de vida urbana a gran escala en el continente americano. Es evidente que la calidad y cantidad de productos, así como la combinación de alimentos lograron mantenerlos en condiciones adecuadas de salud durante siglos de tal manera que pudieron organizarse y destacar en el comercio, en la arquitectura, en las artes, y otras actividades.

Ante la preocupación que nos causan las noticias actuales que hablan de grandes problemas de obesidad y diabetes, ¿no será el momento de voltear nuestra mirada para encontrar las evidencias de civilizaciones anteriores que lograron alimentarse adecuadamente?

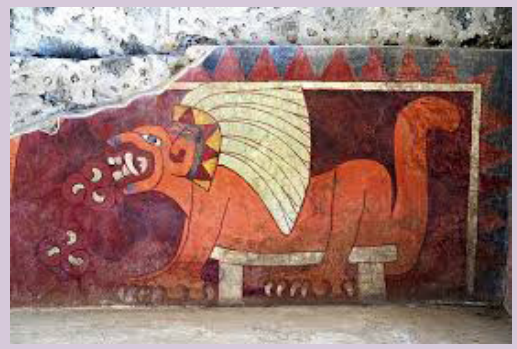

Este libro nos muestra como los estudios científicos modernos nos permiten disponer de información que nos indica que productos y de qué forma se prepararon para alimentar a más de 100 mil teotihuacanos que trabajaron, comieron, durmieron, y murieron hace más de 1500 años en el sitio que a veces visitamos como turistas y que ahora nos entrega esta información para que la utilicemos en nuestro beneficio.

Luis Barba
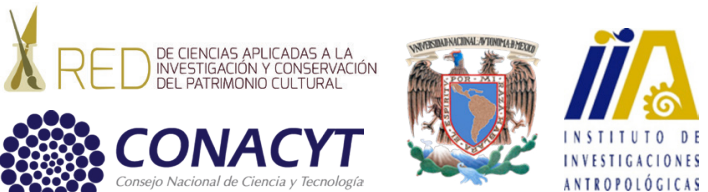

INSTITUTO DE

INVESTIGaCIONES

ANTROPOLOGICAS

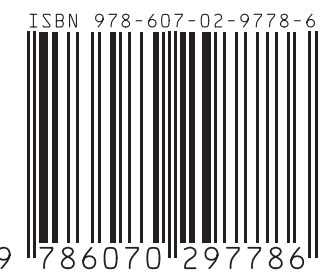

